\title{
Mineral Resources of the Deep Creek Mountains Wilderness Study Area, Juab and Tooele Counties, Utah
}
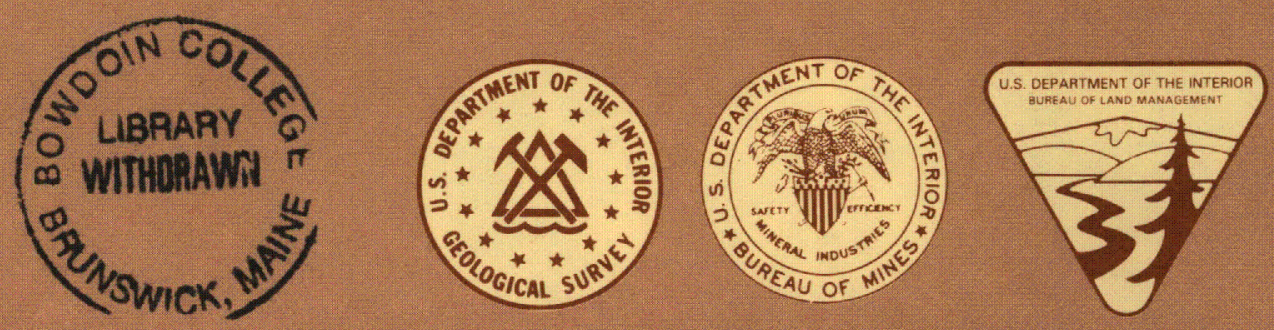

\section{U.S. GEOLOGICAL SURVEY BULLETIN 1745-C}

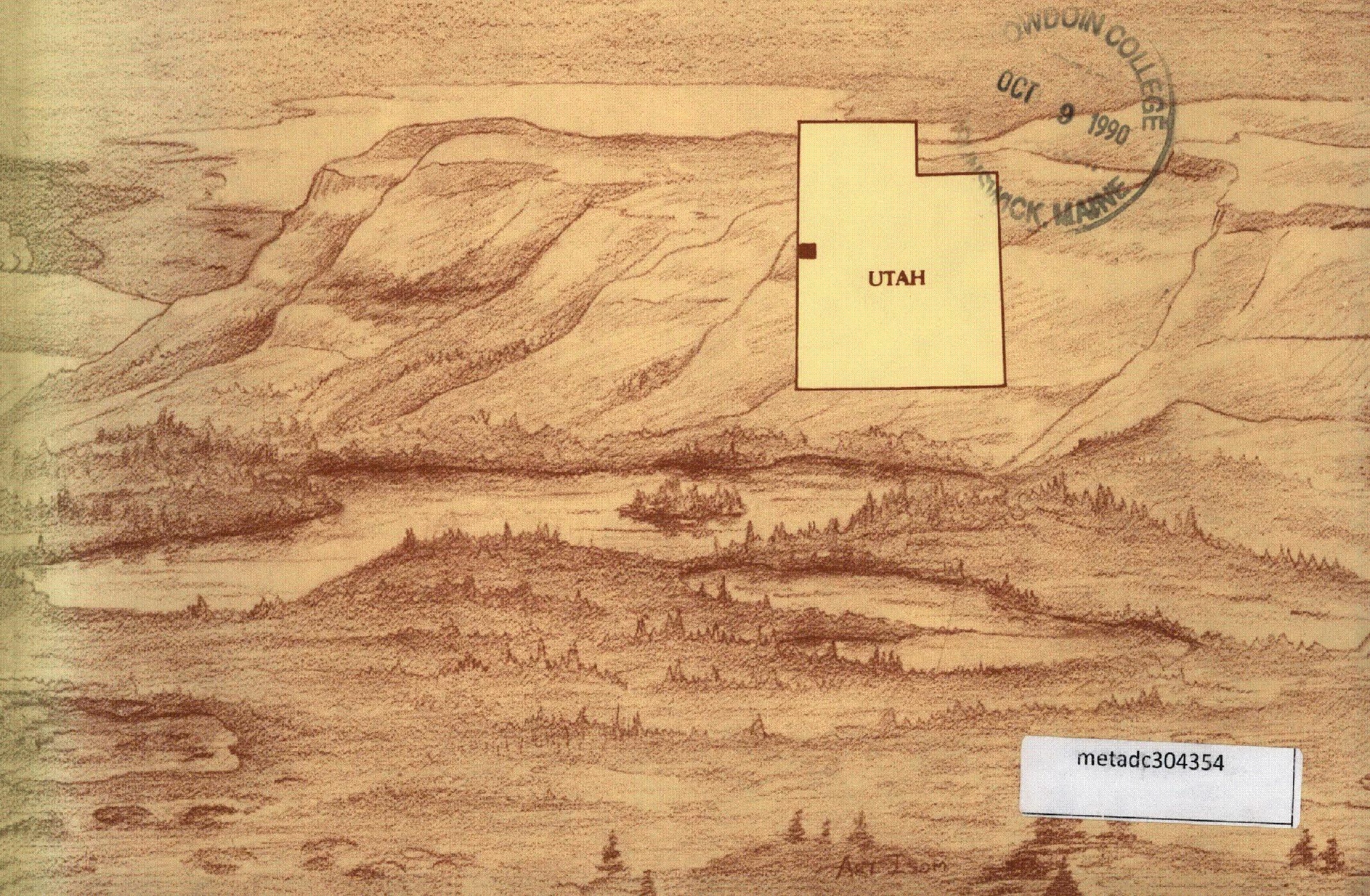


Chapter C

\section{Mineral Resources of the \\ Deep Creek Mountains Wilderness Study Area, Juab and Tooele Counties, Utah}

By CONSTANCE J. NUTT, DAVID R. ZIMBELMAN, DAVID L. CAMPBELL, and JOSEPH S. DUVAL

U.S. Geological Survey

BRIAN J. HANNIGAN

U.S. Bureau of Mines 


\title{
DEPARTMENT OF THE INTERIOR
}

\author{
MANUEL LUJAN, JR., Secretary
}

U.S. GEOLOGICAL SURVEY

Dallas L. Peck, Director

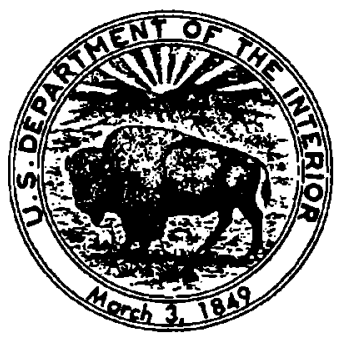

Any use of trade, product, or firm names in this publication is for descriptive purposes only and does not imply endorsement by the U.S. Government.

UNITED STATES GOVERNMENT PRINTING OFFICE: 1990

For sale by the

Books and Open-File Reports Section

U.S. Geological Survey

Federal Center

Box 25425

Denver, CO 80225

\section{Llbrary of Congress Cataloging-In-Publication Data}

Mineral resources of the Deep Creek Mountains Wilderness Study Area, Juab and Tooele Counties, Utah / by Constance J. Nutt ... [et al.].

p. cm. - (U.S. Geological Survey bulletin ; 1745-C) (Mineral

resources of wilderness study areas-northwestern Utah ; ch. C) (Studies related to wilderness)

Includes bibliographical references (p. ).

Supt. of Docs. no.: I 19.3:1745-C

1. Mines and mineral resources-Utah-Deep Creek Mountains

Wilderness. 2. Deep Creek Mountains Wilderness (Utah) I. Nutt, Constance

J. II. Series. III. Series: Mineral resources of wilderness study areasnorthwestern Utah; ch. C.

QE75.B9

no. $1745-C$

[TN24.U8]

$557.3 \mathrm{~s}-\mathrm{dc} 20$

$\left[553^{\prime} .09792^{\prime} 44\right]$

90-3783 


\section{STUDIES RELATED TO WILDERNESS}

\section{Bureau of Land Management Wilderness Study Areas}

The Federal Land Policy and Management Act (Public Law 94-579, October 21, 1976) requires the U.S. Geological Survey and the U.S. Bureau of Mines to conduct mineral surveys on certain areas to determine the mineral values, if any, that may be present. Results must be made available to the public and be submitted to the President and the Congress. This report presents the results of a mineral survey of the Deep Creek Mountains (UT-020-060/UT-050-020) Wildemess Study Area, Juab and Tooele Counties, Utah. 



\section{CONTENTS}

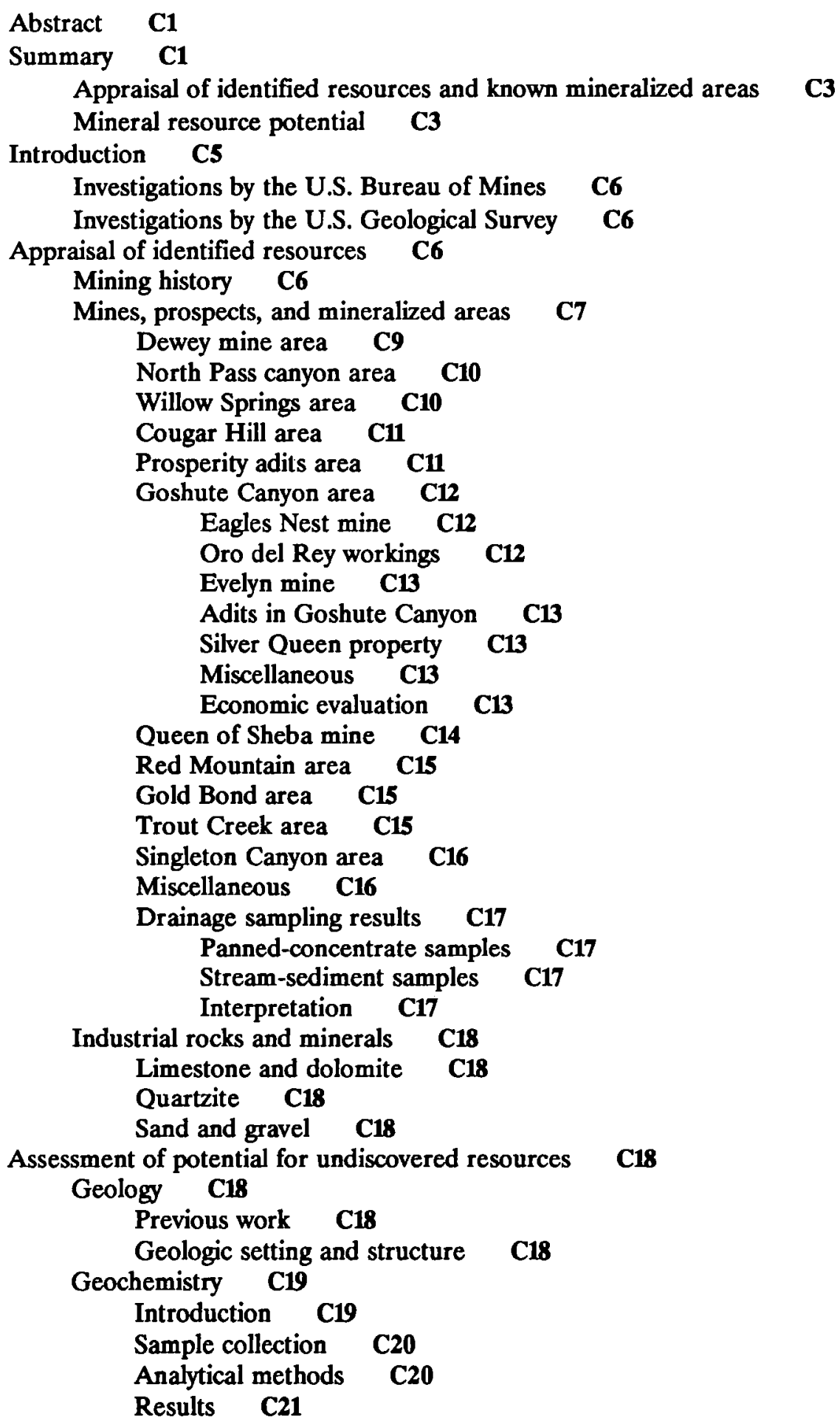




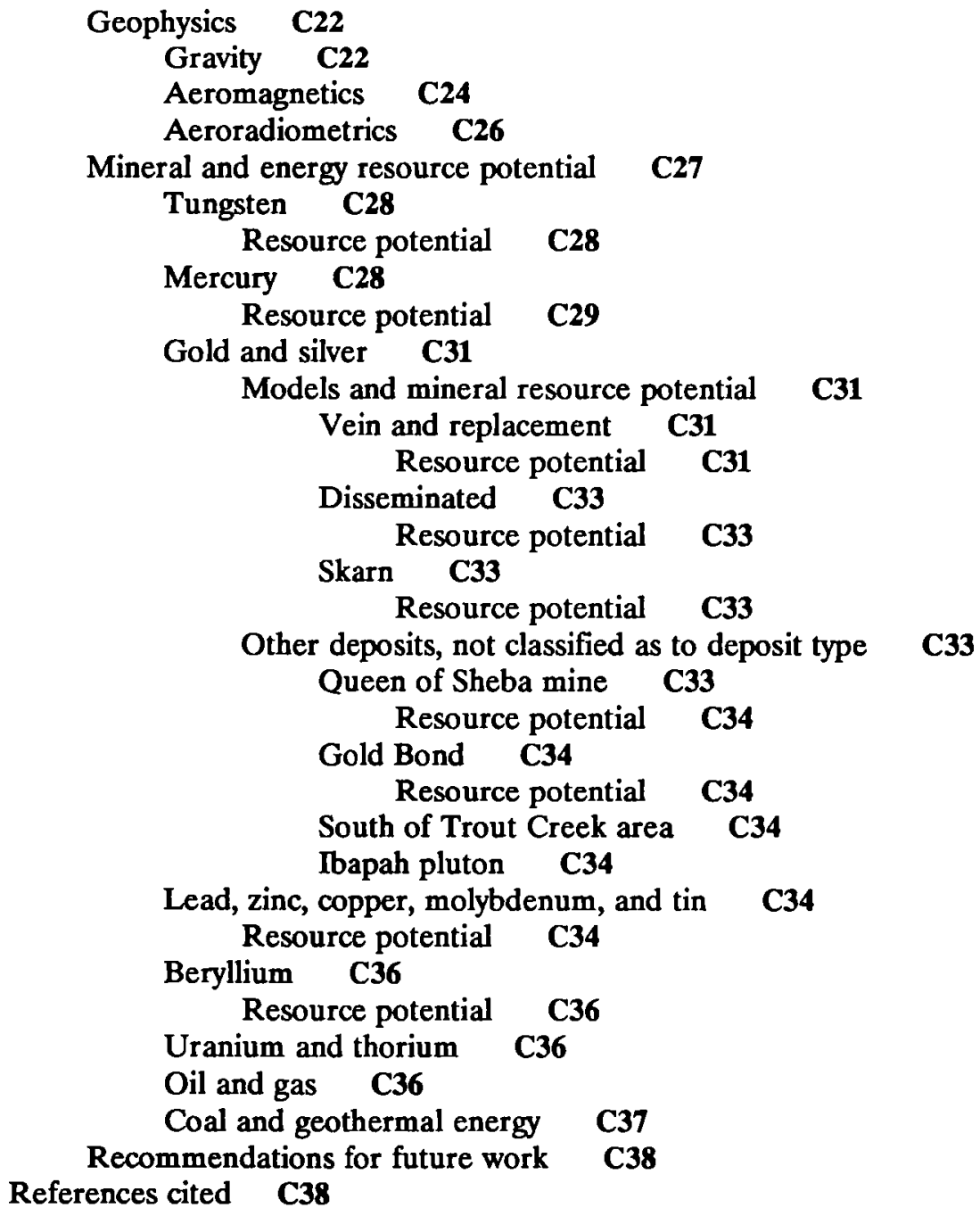

PLATE

[Plate is in pocket]

1. Map showing mineral resource potential, geology, stream-sediment and heavymineral concentrate sample localities, and anomalous elements in the Deep Creek Mountains Wilderness Study Area, Juab and Tooele Counties, Utah.

\section{FIGURES}

1-5. Maps showing:

1. Location of Deep Creek Mountains Wilderness Study Area C2

2. Summary of mineral resource potential of the Deep Creek Mountains Wilderness Study Area C4

3. Mines and adits in the Goshute Canyon area C8

4. Location of patented and unpatented claims in and near the Deep Creek Mountains Wilderness Study Area C9

5. Location of possible faults suggested by gravity gradients C23 
6. Aeromagnetic map of the Deep Creek Mountains Wilderness Study Area and vicinity C25

7. Histogram of measured magnetic susceptibilities of $\mathbf{3 3}$ rock samples from the Ibapah pluton C26

8. Models showing degree of fit with observed aeromagnetic field for different assumed shapes of the Ibapah pluton C27

9-13. Maps showing mineral resource potential for element indicated in the Deep Creek Mountains Wilderness Study Area:

9. Tungsten C29

10. Mercury C30

11. Gold and silver C32

12. Lead, zinc, copper, molybdenum, tin C35

13. Beryllium C37

\section{TABLES}

1. Limits of determination for the spectrographic analyses of rock and streamsediment samples from in and near Deep Creek Mountains Wilderness Study Area $\mathbf{C 2 0}$

2. Chemical methods used for analysis of selected elements, Deep Creek

Mountains Wilderness Study Area C21

3. Minimum element values considered anomalous and number of samples that are at or above these values for stream drainage samples from the Deep Creek Mountains Wilderness Study Area C21

4. Minimum element values considered anomalous for rock samples, Deep Creek Mountains Wilderness Study Area C22

5. Geochemical suites of anomalous elements in rock samples from in and near the Deep Creek Mountains Wilderness Study Area C22 



\title{
Mineral Resources of the Deep Creek Mountains Wilderness Study Area, Juab and Tooele Counties, Utah
}

\author{
By Constance J. Nutt, David R. Zimbelman, \\ David L. Campbell, and Joseph S. Duval \\ U.S. Geological Survey \\ Brian J. Hannigan \\ U.S. Bureau of Mines
}

\section{ABSTRACT}

The Deep Creek Mountains Wilderness Study Area (UT-020-060/UT-050-020) includes most of the Deep Creek Range of west-central Utah. The area is near the UtahNevada State line, south of Wendover, Utah, and northwest of Delta, Utah. Eleven areas of mineralized rock in and near the study area were evaluated by the U.S. Bureau of Mines. Four of these areas contain identified resources: (1) an indicated resource of 5,000 short tons of 16.5 ounces silver per short ton, 4.1 percent lead, 4.6 percent zinc, and 0.25 percent copper, at the Willow Springs area, which is almost surrounded by the study area in the northeast corner although it is not part of the study area; (2) an indicated gold resource of 774,000 short tons of 0.4 ounces per short ton and an inferred gold resource of 5.7 million short tons of 0.4 ounces per short ton in the Goshute Canyon area immediately east of the study area; (3) an indicated gold resource of 75,000 short tons of 0.22 ounces per short ton in the Queen of Sheba mine just west of the study area; and (4) an inferred gold resource of 3,800 short tons of 0.26 ounces per short ton in the Gold Bond area immediately east of the study area. Gold resources at the Queen of Sheba mine and at the Gold Bond area are too low grade to warrant an economic evaluation. The small tonnage and thin vein width of the deposit at the Willow Springs area combine to make that deposit subeconomic.

Manuscript approved for publication June 11, 1990.
Much of the study area is underlain by Late Proterozoic to Lower Cambrian quartzite and Middle Cambrian to Pennsylvanian carbonate rock and contains vast quantities of limestone, dolomite, and quartzite. The limestone and dolomite are suitable for agricultural uses, and the quartzite is suitable for use in the production of eighth- and ninth-quality amber glass. These commodities are not likely to be mined in the foreseeable future because the study area is so remote.

Most of the study area has moderate to high potential for undiscovered tungsten, mercury, gold, silver, lead, zinc, copper, molybdenum, tin, and (or) beryllium resources. The entire study area has low potential for undiscovered uranium, thorium, oil, gas, coal, and geothermal energy resources.

\section{SUMMARY}

The U.S. Geological Survey (USGS) and the U.S. Bureau of Mines (USBM), at the request of the U.S. Bureau of Land Management (USBLM), conducted a mineral survey of 57,384 acres of the Deep Creek Mountains Wilderness Study Area in Juab and Tooele Counties, Utah (fig. 1). The survey included new geologic mapping, regional geochemical sampling, evaluation of geophysical characteristics, and examination, mapping, and sampling of mines and prospects.

The Deep Creek Mountains Wilderness Study Area, referred to here as "the study area," is in the eastern Great Basin physiographic province, which is characterized by north-trending basins and ranges and a semiarid climate. The Deep Creek Range rises dramatically from alluvium-filled basins and is cut by steep-walled, east-west canyons. Ibapah Peak, which is in the center of the range, is higher than 12,000 feet and total relief is more than 7,500 feet (pl. 1). 


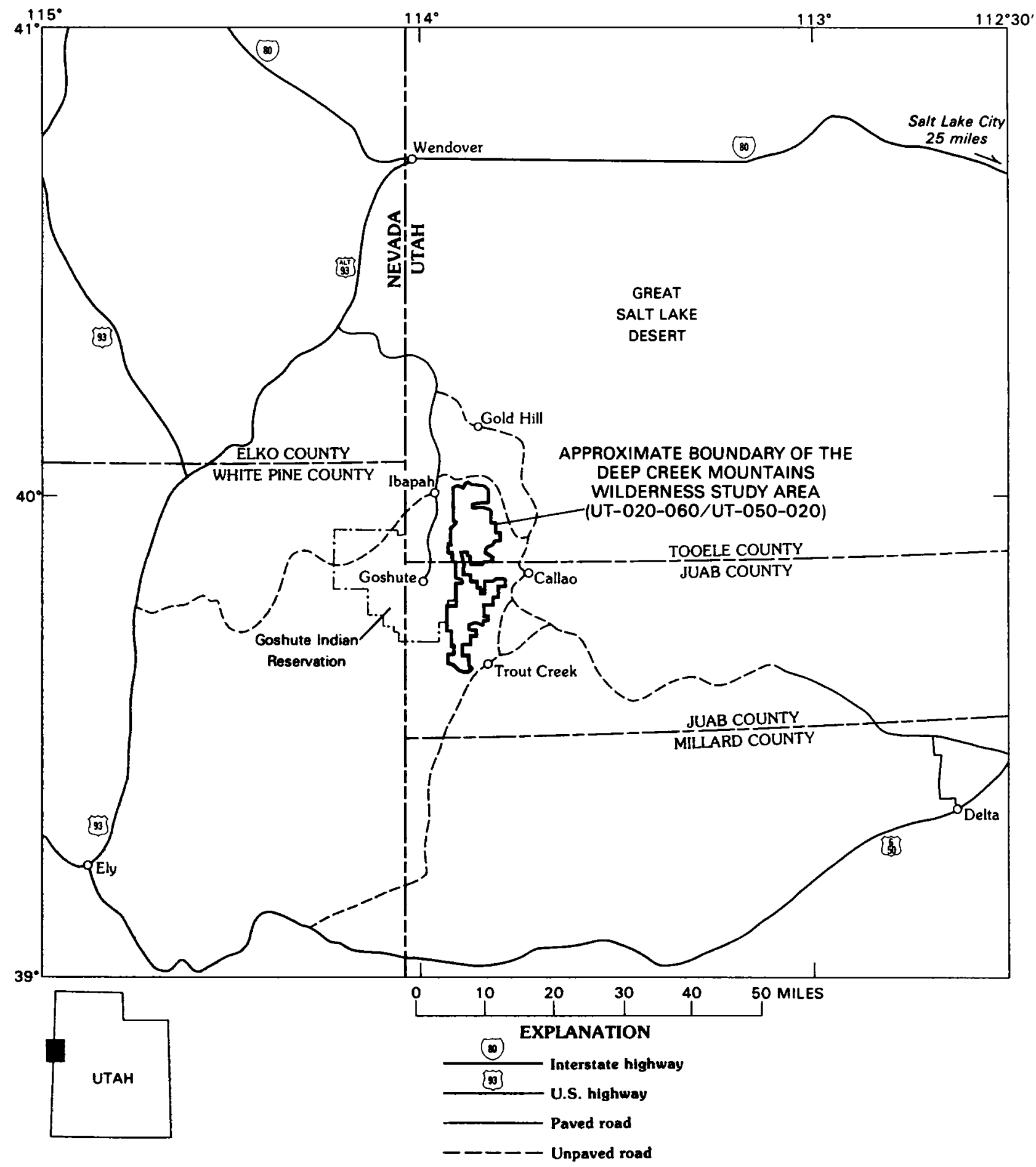

Figure 1. Index map showing location of Deep Creek Mountains Wilderness Study Area, Juab and Tooele Counties, Utah.

Paved roads that tum to gravel provide access to the Deep Creek Range, and jeep trails lead to the study area boundary.

The Deep Creek Range is a west-titted block of Late Proterozoic to Permian (see geologic time chart in the Appendix) metasedimentary and sedimentary rocks cut by Cretaceous(?) and Tertiary intrusive rocks and, at the southern end, overlain by Tertiary volcanic rocks. The study area includes a southern domain of Late Proterozoic metasedimentary clastic rocks and subordinate carbonate rocks, a central part underlain by the Tertiary Ibapah pluton, and a northern domain of Late Proterozoic to Middle Cambrian clastic rocks overlain by a thick section of Paleozoic 
carbonate rocks and subordinate shale and sandstone. The range is bounded by alluvium-covered faults on the east and west.

The regional aeromagnetic map suggests that the Ibapah pluton is rootless and that a magnetic source (igneous body) may be buried at the east side of the range. Because of rugged topography in the Deep Creek Range, magnetic bodies, especially where shallow, might not have been detected by aeromagnetic surveying. Gravity coverage of the study is too sparse to reflect local geological details.

\section{Appraisal of Identified Resources and Known Mineralized Areas}

The study area includes or is near the Willow Springs, Spring Creek, Granite Creek, and Trout Creek mining districts and is 2-4 miles south of the Gold Hill, or Clifton, mining district. Concentrations of metals and pathfinder elements characteristic of base- and preciousmetal deposits were found at $\mathbf{1 1}$ areas in and near the study area (pl. 1), and resources were defined at four of these areas.

1. The Willow Springs area in the northeast corner of the study area contains an indicated resource of 5,000 short tons of 16.5 ounces silver per short ton, 4.1 percent lead, 4.6 percent zinc and 0.25 percent copper. This resource is at the Roy mine, which is almost surrounded by, but not included in, the study area. The small tonnage and thin vein width of this deposit combine to make it subeconomic.

2. The Goshute Canyon area is $\mathbf{0 . 1 - 1}$ mile outside the eastern boundary of the study area and contains an indicated gold resource of 774,000 short tons of 0.4 ounces per short ton and an inferred gold resource of 5.7 million short tons of 0.4 ounces per short ton. The gold resource is in fracture-controlled gold-bearing quartz veins in quartzite. The indicated resource has an in-place value of $\$ 143$ million, and the inferred resource has an in-place value of $\$ 1$ billion using a gold price of $\$ 450$ per ounce. The gold resources in the Goshute Canyon area are similar in type and grade to those in the Courthouse vein system in Colorado, which has been studied in detail by the USBM (Scott, 1986). The Courthouse system is a deposit of narrow gold-bearing veins that contains 4 million tons of ore at an average grade of $0.4 \mathrm{oz} / \mathrm{ton}$ (ounces per ton). The Courthouse vein system is marginally economic (Scott, 1986), which means that hypothetically it could be mined commercially by a company skilled in efficient mining of narrow-vein deposits, provided all assumptions prove valid.

3. The Queen of Sheba mine is 1 mile outside the western boundary of the study area and contains an indicated gold resource of 75,000 short tons of 0.22 ounces per short ton. This gold resource is too low grade to warrant an economic evaluation.
4. The Gold Bond area, 1 mile outside the southeastern boundary of the study area, contains an inferred gold resource of 3,800 short tons of 0.26 ounces per short ton at the Inclined Shaft mine. This gold resource is too low grade and too small to warrant an economic evaluation.

Vast quantities of limestone and dolomite, suitable for agricultural uses, and quartzite, suitable for production of eighth- and ninth-quality amber glass, are present in the study area. The high bulk, low unit value of the limestone, dolomite, and quartzite, plus the high transportation costs due to the remote setting, would limit their development to all but local uses. Local demand for these commodities is limited to nonexistent.

Sand and gravel deposits occur along the flanks of the Deep Creek Range outside the study area, but the steep, narrow valleys inside the study area are not suitable for the accumulation of these deposits.

\section{Mineral Resource Potential}

Most of the Deep Creek Mountains Wilderness Study Area has moderate to high resource potential for undiscovered tungsten, mercury, gold, silver, lead, zinc, copper, molybdenum, tin, and (or) beryllium (fig. 2; pl. 1). The entire area has low resource potential for undiscovered uranium, thorium, oil, gas, coal, and geothermal energy.

Parts of both the northern and southern study area have resource potential for tungsten. A small area in the southeastern part of the study area has high resource potential for tungsten (fig. $2 ;$ pl. 1). This part of the study area is west of the Trout Creek area, where vein and replacement tungsten deposits are associated with alaskite. Tungsten is anomalous in heavy-mineral concentrate samples from some streams draining this area. Two areas, one in the northern part and one in the southern part of the study area, have moderate potential for tungsten. These areas include a cluster of drainages from which heavy-mineral concentrate samples were anomalous in tungsten.

Most of the northern study area has high or moderate resource potential for mercury (fig. $2 ;$ pl. 1), and a small part of the southern area has moderate potential for mercury. The part of the northern study area that has a high resource potential for mercury is along and near the Rocky Springs thrust fault. Rocks cut by this thrust fault are anomalous in mercury and host the Cougar Hill mercury mine, which is not included in the study area (pl. 1). The rest of the northern part of the study area has a moderate resource potential for mercury. This rating is based on the presence of anomalous mercury concentrations in rocks from the Chokecherry Canyon area, which is in the study area, and from the Goshute Canyon area and the Dewey mine, 


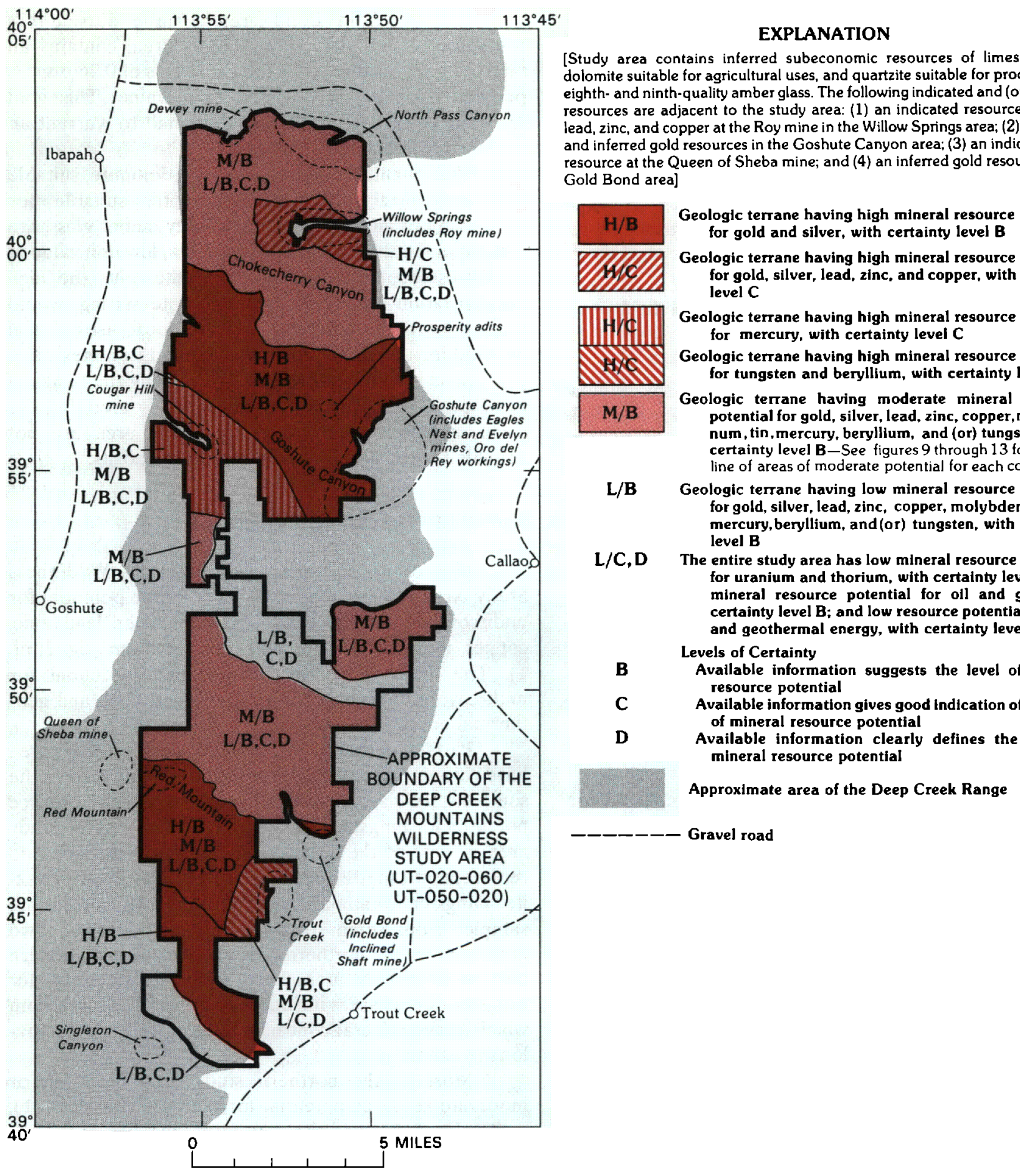

Figure 2. Summary map showing mineral resource potential of the Deep Creek Mountains Wilderness Study Area, Juab and Tooele Counties, Utah.

both of which are just outside the study area (pl. 1). A small area in the southern part of the Deep Creek Range, west of the Trout Creek area, contains rocks that have anomalous mercury concentrations and has a moderate potential for mercury.
Five parts of the study area have a high to moderate resource potential for gold and silver (fig. 2; plate 1). The areas of high potential in both the northern and southern parts of the study area were delineated by (1) anomalous concentrations of gold, silver, or 
pathfinder elements in stream-sediment, heavy-mineral concentrate, or rock samples, (2) proximity to known prospects and indicated and inferred resources at Willow Springs, Goshute Canyon, Queen of Sheba, and Gold Bond, and (3) favorable host rocks, which include carbonate and quartzite. The area of moderate potential in the northern part of the study area was outlined by (1) anomalous concentrations of the pathfinder element barium in heavy-mineral concentrates, (2) the presence of anomalous gold and silver at the Dewey mine area, just north of the study area boundary, and at the Willow Springs area and Chokecherry Canyon to the south, and (3) anomalous silver in a heavy-mineral concentrate sample from Chokecherry Canyon. The area of moderate potential in the central part of the study area includes hematite-stained monzogranite of the Ibapah pluton, some of which has trace concentrations of silver and (or) gold.

Much of the northern part of the study area has high to moderate resource potential for lead, zinc, and copper, and the southern part has moderate potential for lead, zinc, copper, molybdenum, and (or) tin. The Willow Springs area in the north has an indicated silver-leadzinc-copper resource that is not included in the study area, and has a high potential for undiscovered lead, zinc, and copper resources (fig. 2; pl. 1). Three other areas have a moderate potential for undiscovered lead, zinc, and copper resources: near the Dewey mine, south of the Willow Springs area (including Chokecherry Canyon and the Prosperity adits), and the south-central part of the study area (fig. 2 ; pl. 1). Areas of moderate potential were identified by anomalous concentrations of lead, zinc, and copper in rock samples from these areas and by anomalous amounts of lead and zinc in heavy-mineral concentrate samples (pl. 1). The southern part of the study area, including near the Trout Creek, Red Mountain, and Queen of Sheba mine areas, has moderate potential for molybdenum and tin. This area of moderate potential was identified by anomalous amounts of molybdenum and tin in rock samples and heavymineral concentrates and the proximity of alaskite.

Much of the Deep Creek Mountains Wilderness Study Area has moderate resource potential for beryllium, and the southeastern part west of Trout Creek has high resource potential for beryllium (fig. 2; pl. 1). The assessment is based on the presence of anomalous amounts of beryllium in heavy-mineral concentrate or rock samples, including local ore-grade beryllium enrichment in the Trout Creek tungsten deposits.

The entire study area has low resource potential for uranium and thorium, because the only concentrations of uranium and thorium are in Tertiary and Quaternary placer deposits outside the study area. The resource potential for oil and gas is low because cono- dont CAI values indicate that the hydrocarbons in the study area range from highly mature to overmature. The entire study area has a low potential for coal and geothermal energy.

\section{INTRODUCTION}

The U.S. Geological Survey and U.S. Bureau of Mines studied 57,384 acres of the 68,910-acre Deep Creek Mountains Wilderness Study Area (UT-020-060/UT-050-020) at the request of the U.S. Bureau of Land Management. The study area is in west-central Utah, in Juab and Tooele Counties, near the Utah-Nevada State line (fig. 1). It is about $90 \mathrm{mi}$ (miles) northwest of Delta, Utah, and about $75 \mathrm{mi}$ south of Wendover, Utah, and can be reached from either town by paved roads that turn to gravel. The small towns or communities along the gravel roads at the edge of the study area are Callao and Trout Creek on the east side and Ibapah and Goshute on the west (fig. 1). Supplies can be obtained from Trout Creek and Ibapah. The study area is bounded on the southwest side by the Goshute Indian Reservation. Access to the study area is by foot and by jeep trails, many of which lead to old mines and prospects and end at the study area boundary.

The study area includes most of the Deep Creek Range, a north-northeast-trending range that rises dramatically from the surrounding alluvium-filled basins. The highest peaks are in the center of the range and include Ibapah Peak, at 12,087 $\mathrm{ft}$ (feet) (pl. 1). In comparison, the town of Callao at the eastern base of the mountains is at about $4,400 \mathrm{ft}$. The range is dissected by east-trending, commonly steep-walled narrow canyons. The semiarid climate supports such vegetation as sagebrush, pinyon-juniper, and montane forest.

This report presents an evaluation of the mineral endowment (identified resources and mineral resource potential) of the study area and is the product of several separate studies by the USBM and the USGS. Identified resources are classified according to the system of the U.S. Bureau of Mines and the U.S. Geological Survey (1980), which is shown in the Appendix of this report. Identified resources are studied by the USBM. Mineral resource potential is the likelihood of occurrence of undiscovered metals and nonmetals, industrial rocks and minerals, and of undiscovered energy sources (coal, oil, gas, oil shale, and geothermal). It is classified according to the system of Goudarzi (1984) and is shown in the Appendix. Undiscovered resources are studied by the USGS. 


\section{Investigations by the} U.S. Bureau of Mines

In the fall of 1985, the spring and summer of 1986 , and the spring of 1988, the USBM conducted a mineral investigation of the Deep Creek Mountains Wilderness Study Area (Hannigan, 1990). In addition to field work, a comprehensive literature search was made for information on mines and mineralized areas in and near the study area. Individuals and companies with information on mines and mineralized areas were consulted, and mining claim and oil and gas lease records were obtained from the Utah State Office of the USBLM in Salt Lake City.

Mines, prospects, and mineralized areas in and within 1 mile of the study area were examined, mapped, and sampled, and a reconnaissance for additional mineralized sites was performed. Nine hundred and eighteen samples were taken to aid in delineating the extent of known resources and mineral occurrences.

Samples were analyzed by Chemex Labs, Inc. in Sparks, Nevada. Gold was determined by fire assay; mercury by standard flameless extraction with an atomic absorption finish; and tin by ammonium iodide sublimation, hydrochloric acid extraction, and atomic absorption finish. All other elements were determined by an inductively coupled plasma method. Metal concentrations presented in this report are exactly as reported by the laboratory. Complete sample descriptions and analytical results are available for public inspection at the U.S. Bureau of Mines, Intermountain Field Operations Center, Building 20, Denver Federal Center, Denver, Colorado. These data were used to produce the resource estimates presented in this report.

\section{Investigations by the U.S. Geological Survey}

During 1986, new geologic mapping of the northern part of the Deep Creek Mountains Wilderness Study Area was done by David W. Rodgers, who was under contract to the USGS. Rodgers combined this and previous mapping (Rodgers, 1987) on the southern part of the range to produce a geologic map of the study area (Rodgers, 1989). In addition, geologic features and mines were examined by C.J. Nutt, J.F. Kaminsky, D.R. Zimbelman, and D.B. Stoeser. Geochemical samples were collected by D.R. Zimbelman, Helen Whitney, and T.A. Delaney in 1986 and by D.R. Zimbelman and C.J. Nutt in 1988.

Aeromagnetic and radiometric data were collected in 1977-79 as part of the National Uranium Resource Assessment (NURE) program of the U.S. Department of Energy. The aeromagnetic data were gridded and contoured by R.P. Kucks. Gravity data were compiled in 1986-1987 by Kenneth L. Cook (University of Utah) and Viki Bankey. These geophysical data were evaluated by D.L. Campbell. Radiometric data were processed and evaluated by J.S. Duval.

\section{APPRAISAL OF IDENTIFIED RESOURCES}

\section{By Brian J. Hannigan \\ U.S. Bureau of Mines}

\section{Mining History}

There are four mining districts in or near the Deep Creek Mountains Wilderness Study Area. The boundaries of these districts are imprecisely defined. The Willow Springs district encompasses the workings in the northern part of the Deep Creek Range; the Spring Creek district includes the area around the Queen of Sheba mine; the Granite Creek district contains the Gold Bond properties; and the Trout Creek (Johnson Peak) district is near the mouth of Trout Creek (Butler and others, 1920). In addition, the Gold Hill mining district, also known as Clifton, is 2-4 mi north of the study area. Mining activity has taken place at 10 of 11 mineralized areas in and near the study area. In the following text, these areas (shown on pl. 1) are discussed in geographic order from north to south.

Dewey mine area.-The Dewey mine area is about $1 / 2 \mathrm{mi}$ north of the study area on the west side of South Peak and about $4 \frac{1}{2}$ mi east of Ibapah. Development work was done between 1890 and 1900 , and five claims were patented in 1914. Reportedly, about $800 \mathrm{lb}$ (pound) of silver ore, containing about $\$ 1,800$ worth of silver, was shipped from the property between 1890 and 1900 (Nolan, 1935). The average price of silver at the time was about $\$ 0.74$ per troy ounce (U.S. Department of the Treasury, 1971), which suggests that the recorded production was about $2,400 \mathrm{oz}$ (ounce) of silver. If Nolan's data are correct, the grade of the material was about 5,000 oz silver/short ton. The recent USBM investigation of the site found no ore of this grade and concluded that probably no material of such high grade came from this site. No additional production from the Dewey mine area has been recorded.

North Pass Canyon area. - The North Pass Canyon area is partly in and partly outside the northeastern corner of the study area and about $12 \mathrm{mi}$ northwest of Callao. According to sketchy records, this area was developed in the 1920's. Sixteen claims in Bagley Gulch and on the south side of North Pass Canyon were surveyed for patent in 1926 (Nolan, 1935), but, according to USBLM records, were never granted patents. No production has been recorded. 
Willow Springs area.-The Willow Springs area is not in the study area but is almost surrounded by it in the northeast corner of the Deep Creek Range about $10 \mathrm{mi}$ northwest of Callao. Five claims about $1 \mathrm{mi}$ west of Willow Springs were patented in 1898 (Thomson, 1973). In 1917, the Roy mine (also known as the Lead Carbonate mine) produced 8 st (short tons) of ore yielding $144 \mathrm{oz}$ silver and 5,920 lb lead (Nolan, 1935). Nolan also speculated that additional small shipments were made but not reported.

Cougar Hill area.- The Cougar Hill (also referred to as Conger Hill in Thomson, 1973) area is inside the western boundary of the study area and about $9 \mathrm{mi}$ southeast of Ibapah. Work on the property was first reported in the early 1930's, and later a retort was built to process mercury (Thomson, 1973). Although some mercury was produced, there are no exact records of dates and amounts of production. Hilpert (1964) reported sporadic production of less than 200 flasks (one flask contains $76.5 \mathrm{lb}$ of mercury).

Prosperity adits area.-The Prosperity adits area is inside the eastern boundary of the study area on the south side of Reilly Canyon and about $7 \mathrm{mi}$ west of Callao. Work on the property was first reported in 1895 and continued until 1914 (Thomson, 1973). No record of production was found.

Goshute Canyon area.-The Goshute Canyon area is about $1 \mathrm{mi}$ east of the eastern boundary of the study area and $6 \mathrm{mi}$ west of Callao. The area comprises the Eagles Nest mine, the Oro del Rey workings, the Evelyn mine, the adits in Goshute Canyon, and the Silver Queen property (fig. 3). The most recent mining in this area was the startup of the Evelyn mine by the Kibbe Co. of Salt Lake City, Utah, who acquired the property in 1979 and began exploration and development. A crusher and heap leach pads were emplaced at the mouth of Goshute Canyon in 1982. About $2,000 \mathrm{ft}$ of underground workings were developed along and near a gold-bearing quartz vein, and stoping was done along the vein for about 160 $\mathrm{ft}$. An undisclosed amount of gold was produced in 1983. Operation ceased near the end of 1983, but Kibbe Co. has indicated a strong intent to restart the operation (Hollei Gromeman, Kibbe Co., oral commun., July 1986). Although no detailed production records could be found, other mines in the area produced an approximate combined total of $\$ 700,000$ of gold (about $20,000 \mathrm{oz}$ at $\$ 35$ /ounce) between 1934 and 1954 (Thomson, 1973).

Queen of Sheba mine.-The Queen of Sheba mine area is about $1 \mathrm{mi}$ outside the western boundary of the study area and $16 \mathrm{mi}$ south of Ibapah. Metallic minerals were reported at the property in 1888 , and work has continued sporadically since then (Thomson, 1973). The eight patented claims currently are owned by the Queen of Sheba Mining Co., Salt Lake City, Utah. Although conflicting production records make it impossible to determine exact production figures, the mine has produced at least $5,000 \mathrm{oz}$ gold and $8,800 \mathrm{oz}$ silver. (Alan Fishler, Queen of Sheba Mining Co., oral commun., July 1986).

Gold Bond area.-The Gold Bond area is just outside the eastern boundary of the study area and about $11 \mathrm{mi}$ southwest of Callao. Metallic minerals were first reported in 1931, and, although the claims were surveyed for patent, they were not taken to patent. In 1934, about $10 \mathrm{oz}$ of gold were produced from the property (Thomson, 1973).

Trout Creek area.- The Trout Creek area is just outside the eastern boundary of the study area and about $12 \mathrm{mi}$ southwest of Callao. Ten claims were patented after tungsten was discovered in the area in 1916. In 1940 and 1942, 18 stu (short ton units) of tungsten were produced from the Apex mine. In 1955, the Trout Creek mine produced 41 stu (Everett, 1961), and, according to personal records of the claim owner, about 340 stu were produced from this mine in 1977 and 1978 (Joseph Nelson, written commun., April 1986). A short ton unit of tungsten is equivalent to $20 \mathrm{lb}$ of tungsten trioxide $\left(\mathrm{WO}_{3}\right)$ and contains $15.86 \mathrm{lb}$ of tungsten. In 1942 and $1943,2,800 \mathrm{lb}$ lead, $29,000 \mathrm{lb}$ zinc, and $225 \mathrm{oz}$ silver were produced from the Trout Creek mine (Perry and McCarthy, 1976). A gravity mill was constructed in Trout Creek Canyon and operated in 1952 and 1953. In 1956, another gravity mill was constructed at the mouth of Granite Canyon (Thomson, 1973). Western Beryllium Co. drilled the area in 1961 and 1962 in an attempt to delineate beryllium resources (Perry and McCarthy, 1976).

Singleton Canyon area.-The Singleton Canyon area is 1 mi outside the southwestern corner of the study area and about $23 \mathrm{mi}$ south of Ibapah. According to sketchy records, development in this area took place in the 1960's (Thomson, 1973). No production has been recorded.

Current mining claims and leases.-According to USBLM records, as of December 1989, there were 28 patented mining claims and 350 current unpatented mining claims in or within $1 \mathrm{mi}$ of the study area (fig. 4). As of May 22, 1987, there were no oil and gas leases in the study area.

\section{Mines, Prospects, and Mineralized Areas}

The literature search and field examination of the Deep Creek Mountains Wilderness Study Area indicate that 11 areas contain possible mineral resources and occurrences in or near the study area (pl. 1). The following commodities were reported to be present, or were discovered during the field investigation: barium, beryllium, copper, fluorine, gold, lead, mercury, silver, tungsten, and zinc. Vast quantities of limestone and dolomite and high-silica quartzite, suitable for some 


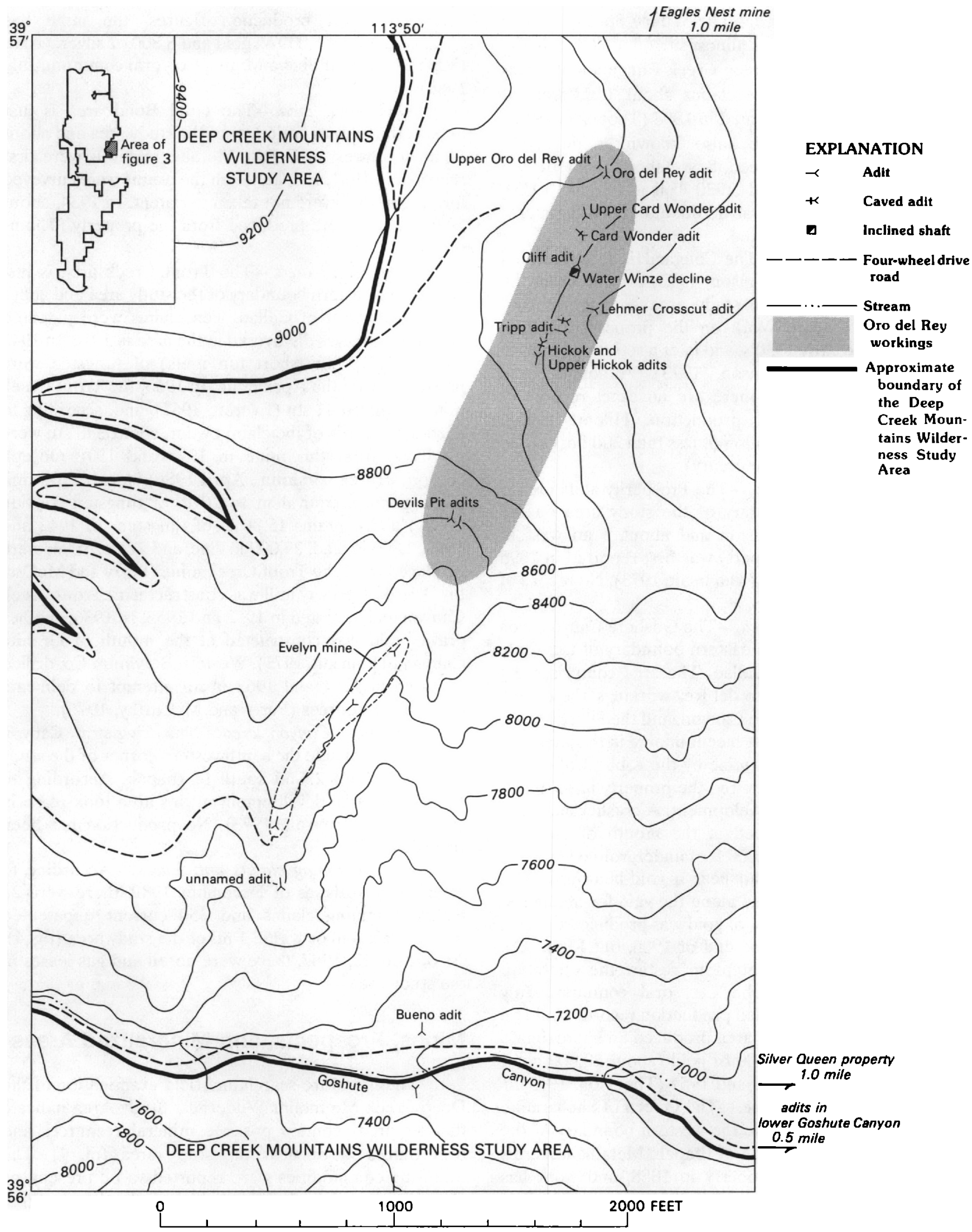

Figure 3. Index map of mines and adits in the Goshute Canyon area. Contour interval, 200 feet. 


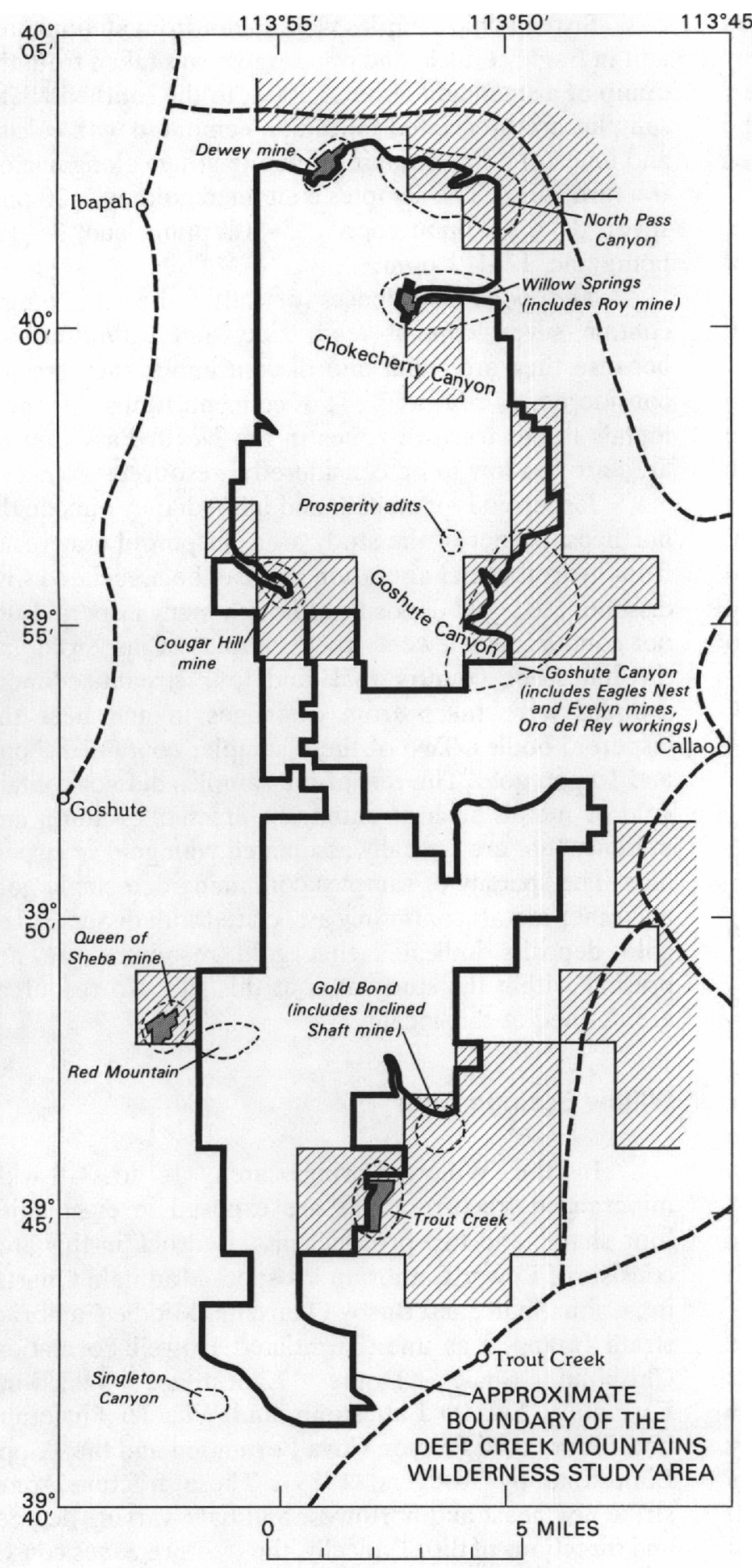

Section with current unpatented claim as of December 1989

Figure 4. Location of patented and unpatented claims in and near the Deep Creek Mountains Wilderness Study Area, Juab and Tooele Counties, Utah.

industrial uses, are present throughout the study area. In the following text, the mineralized areas are discussed in geographical order from north to south. Industrial rocks and minerals are discussed following the sections on mineralized areas.

\section{Dewey Mine Area}

At the Dewey mine, about $1 / 2 \mathrm{mi}$ north of the study area boundary, a 100-ft-wide, northeast-trending, steeply dipping breccia zone in Silurian Laketown Dolostone 
crops out and is exposed in three adits, one shaft, and three prospect pits. This breccia, which is cemented by silica and calcite and contains limonite, is exposed for about 1,800 ft from Sevy Canyon northeast to the workings. The breccia zone trends toward the study area but is not exposed inside the boundary.

One select sample of quartz vein with malachite, limonite, and galena contained gold, $35 \mathrm{ppb}$ (parts per billion); silver, $95.4 \mathrm{oz} / \mathrm{st}$; cadmium, $299 \mathrm{ppm}$ (parts per million); copper, 3,850 ppm; lead, 12,650 ppm; tungsten, $150 \mathrm{ppm}$; and zinc 4,640 ppm. This sample was selected from a small pile of material left on an adit dump. No rock resembling the material in this pile was found in place. The other 13 samples taken from the Dewey mine area contained the following concentrations of precious and base metals: gold, $<5-10 \mathrm{ppb}$; silver, $0.5-38 \mathrm{ppm}$; cadmium, 1-26.5 ppm; copper 2-67 ppm; lead, 30-240 ppm; and zinc, 20-1,125 ppm. Concentrations of these metals are too low and too sporadically distributed to indicate a resource in the Dewey mine area.

\section{North Pass Canyon Area}

At the North Pass Canyon area, which is partly within and partly outside the study area, 1- to 6-ft-wide exposed fracture zones generally strike north to northwest and dip to the west. Bedrock in this area consists of Lower Cambrian Prospect Mountain Quartzite, Cabin Shale, and Busby Quartzite, and Middle Cambrian strata (mapped as undifferentiated Howell Formation, Chisholm Shale, Dome Limestone, Whirlwind Formation, Swasey Limestone, and Wheeler Shale by Rodgers, 1989). These fracture zones are exposed in two adits, two shafts, and three prospect pits. They contain an abundance of limonitic gouge and minor pods or lenses of sulfide-bearing quartz. Because the fracture zones weather easily, they cannot be traced outside the workings.

Pods of sulfide-bearing quartz along fractures are exposed in a shaft and two prospect pits. These pods generally are less than $5 \mathrm{ft}$ wide and extend along strike for no more than $20 \mathrm{ft}$. Select samples of the most visibly mineralized sulfide-bearing quartz from these locations had concentrations of as much as $7.58 \mathrm{oz} / \mathrm{st}$ silver, 3,930 ppm copper, 5.36 percent lead, 2.69 percent zinc, 180 ppm cadmium, and 100 ppm tungsten. A chip sample across one of these pods had considerably lower concentrations of base and precious metals: silver, 4 ppm; cadmium, 31.5 ppm; copper, 92 ppm; lead, 900 ppm; and zinc, $758 \mathrm{ppm}$.

Chip samples were taken across the fracture zones at the shaft, the prospects, and also at a nearby shaft. These samples contained gold, $<5-5 \mathrm{ppb}$; silver, 1.8-4 ppm; copper, 8-162 ppm; lead, 64-695 ppm; zinc, 26-345 ppm.
Sixteen chip samples were taken from an unnamed adit in Bagley Gulch, and one sample was taken from the dump of a small adit about 2,500 ft to the southeast. The samples are brecciated limestone cemented with calcite, and limestone that contains limonite gouge along narrow fracture zones. The samples contained gold, $<5-20 \mathrm{ppb}$; silver, 0.5-12.5 ppm; copper, 5-107 ppm; lead, 35-150 ppm; zinc, 12-191 ppm.

The pods and lenses of sulfide-bearing quartz contain silver, copper, lead, zinc, and cadmium, but because they are small and discontinuous they are not considered a resource. The concentrations of these metals in the fracture zones in the North Pass Canyon area are too low to be considered a resource.

Jasperoid is present in and immediately outside the northeast corner of the study area. Jasperoid may result from hydrothermal alteration and can be associated with disseminated gold deposits, although many jasperoids do not contain gold. Twenty rock samples of jasperoid and the limestone country rock and four stream-sediment samples were taken from drainages in and near the jasperoid bodies. Two of these samples contained $5 \mathrm{ppb}$ and $10 \mathrm{ppb}$ gold. The rest of the samples did not contain gold or metals such as antimony, arsenic, bismuth, and mercury that are typically associated with gold in jasperoids. The sparsity of samples containing detectable gold and other metals commonly associated with disseminated gold deposits indicates that gold resources are not present within the study area at this site. No resources are defined at this locality.

\section{Willow Springs Area}

In the Willow Springs area, 1- to 4-ft-wide mineralized fracture zones are exposed in eight adits, four shafts, and two prospect pits. Bedrock in this area consists of Lower Cambrian Prospect Mountain Quartzite, Cabin Shale, and Busby Quartzite, Middle Cambrian strata (mapped as undifferentiated Howell Formation, Chisholm Shale, Dome Limestone, Whirlwind Formation, Swasey Limestone, and Wheeler Shale and undifferentiated Pierson Cove Formation and the Trippe Limestone by Rodgers, 1989). These fracture zones strike northeast and northwest and have varying degrees and directions of dip. Typically, the fracture zones consist of fractured and altered host rock, limonite and limonitic gouge, and minor calcite; in the Roy (Lead Carbonate) mine sulfides and oxides are also present. These fracture zones weather easily and generally cannot be traced outside the workings.

The most highly mineralized structure in the Willow Springs area is exposed in the Roy mine. Chalcopyrite, galena, pyrite, malachite, sphalerite, and chalcocite are present as a vein formed by replacement along a narrow fracture zone in the Middle Cambrian strata 
(map unit $€ w h$ ). The vein is exposed for about $140 \mathrm{ft}$ along strike and about $180 \mathrm{ft}$ downdip. Samples from the vein contain a weighted average concentration of $\mathbf{1 6 . 5}$ $\mathrm{oz}$ silver/st, 4.1 percent lead, 4.6 percent zinc, and 0.25 percent copper across an average width of 13.4 in. Using this width and a tonnage factor of $12.5 \mathrm{ft}^{3} / \mathrm{st}$ (cubic feet per short ton), there is an indicated subeconomic resource of $5,000 \mathrm{st}$ of mineralized rock present along the main structure. This resource totals at least $82,500 \mathrm{oz}$ silver, $410,000 \mathrm{lb}$ lead, $460,000 \mathrm{lb}$ zinc, and $25,000 \mathrm{lb}$ copper. The small tonnage and thin vein width combine to make this deposit subeconomic.

Six samples of the limestone country rock were collected from the footwall and hanging wall of the structure in the Roy mine. Except for low concentrations of lead and zinc, the samples do not contain base- or precious-metal concentrations significantly above the detection limits of the analytical methods used.

Thirty-one samples were taken from fracture zones exposed in other accessible adits, shafts, and prospect pits, and from dumps of caved adits and inaccessible shafts in the Willow Springs area. The fracture zones are not extensive and cannot be traced past the workings. Low concentrations of copper, lead, and zinc are found in samples taken from these fracture zones, and two of the four samples from an unnamed adit and shaft contain $420 \mathrm{ppb}$ and $195 \mathrm{ppb}$ gold, but these concentrations are too low and the structures too discontinuous to indicate the presence of a resource.

\section{Cougar Hill Area}

At Cougar Hill, the Rocky Springs thrust fault that placed Lower Cambrian Prospect Mountain Quartzite against Lower and Middle Devonian Sevy Dolostone also localized ore. The thrust fault strikes N. $60^{\circ} \mathrm{W}$. and dips $50^{\circ}$ to the south and can be mapped for about $5 \mathrm{mi}$ inside the study area. Fracture zones associated with the thrust fault generally have a similar orientation. Barite and cinnabar are present as coatings on brecciated dolomite in the footwall of the fault.

The fault and related fracture zones are exposed in workings consisting of one adit, two shafts, three open cuts, and three prospect pits. These zones generally contain brecciated dolomite that includes calcite, cinnabar, limonite, and gouge. All the samples taken from the workings in the Cougar Hill area contain mercury. The highest mercury concentrations, 0.143 percent, are in chip samples taken from a shear zone exposed in the lowest open cut, the adit, and the shaft that connects them, and from a select sample taken from the dump of a prospect pit along the same trend. The mercury is concentrated in these sampled rocks and decreases in concentration in both directions along strike.
The samples taken from the shaft, the open cuts, and prospect pits also contain sporadically distributed silver, bismuth, cadmium, copper, molybdenum, lead, tungsten, and zinc. The concentrations of base and precious metals in the samples taken at these workings are too sporadically distributed and generally are not high enough to define a resource.

\section{Prosperity Adits Area}

Workings in the Prosperity adits area consist of the Prosperity "101," the upper of two adits, and the Prosperity "102," which is the lower. The major mineralized structure at this location is a $16-\mathrm{ft}$-wide fracture zone in Middle Cambrian strata (undifferentiated Pierson Cove Formation and Trippe Limestone). This fracture zone, exposed in the Prosperity "101," strikes northeast and dips to the northwest. The zone consists of highly fractured limestone healed with calcite; limonite, galena, malachite, and azurite are common. In the Prosperity "102," fracture zones containing limonitic gouge and calcite occur in limestone. These fractures generally trend northeast and dip steeply to the northwest. The structures present in both adits are not exposed outside the workings.

Select samples of the most visibly mineralized material on the dump of the Prosperity "101" have concentrations of as much as $\mathbf{4 7 . 2}$ percent copper, 33.2 percent lead, and 1,615 ppm zinc. Chip samples across the major structure exposed in this adit have lower concentrations of these base metals. The high concentrations of copper and lead in samples taken from the main fracture zone and from the dump of the Prosperity "101" suggest the presence of a copper and lead resource at this locality, but there are insufficient exposures to define a resource.

Samples of the host limestone, fractured limestone, and limonite gouge in the Prosperity "101" adit contained gold, <5-60 ppb; silver, 0.5-21 ppm; copper, 26-100 ppm; lead, 110-755 ppm; and zinc, 15-114 ppm. The concentrations of metals are too low and the amount of mineralized rock too small to define a resource extending beyond the main structure into the narrow fracture zones or the host rock.

Nine chip samples were taken from the Prosperity "102." The samples are of fractured limestone and limonite gouge along narrow fracture zones and of limestone host rock that contains calcite veinlets. Concentrations of base and precious metals in the samples are as follows: gold, 5-90 ppb; silver, 0.5-1.5 ppm; copper, 6-87 ppm; lead, 55-1,140 ppm; and zinc, 9-103 ppm. Although the fracture zones and limestone exposed in the Prosperity "102" contain minor gold and lead, the concentrations of these metals are too low to indicate the presence of a resource at this site. 


\section{Goshute Canyon Area}

The Goshute Canyon area is within $1 \mathrm{mi}$ of the study area boundary, and comprises the Eagles Nest mine, the Oro del Rey workings, the Evelyn mine, the adits in Goshute Canyon, and the Silver Queen property (fig. 3). Seventeen adits, 5 caved adits, 1 tunnel, 2 declines, 4 shafts, and 2 prospect pits are in the Goshute Canyon area.

Fractures exposed in the Eagles Nest mine, Oro del Rey workings, Evelyn mine, and adits in Goshute Canyon cut quartzite and host auriferous quartz veins. The veins contain disseminated galena, chalcopyrite, and pyrite. Fractures hosting veins strike N. $10^{\circ}-15^{\circ}$ E. and dip steeply to the southeast. The mine workings in the Goshute Canyon area are in the Lower Cambrian Prospect Mountain Quartzite, except in lower Goshute Canyon and at Silver Queen where they are in Late Proterozoic quartzite.

Several factors contribute to the difficulty in tracing the extent of the gold-bearing veins in the Goshute Canyon area. Because of silicified rock along the vein edges, quartz veins merge with the host quartzite and are difficult to detect. Fracture zones in the quartzite are numerous, branched, and in places covered by talus. In addition, the terrain in this area is so rugged that mapping and sampling are difficult. Extensive sampling and the use of technical climbing techniques would be required to accurately identify, map, and sample the structures in the Goshute Canyon area.

An attempt was made to determine the north and south extent of the vein system. Panned-concentrate and stream-sediment samples were taken at the mouths of the canyons that drain the area around the vein system. Gold was present in panned-concentrate samples taken from Reilly, Goshute, and Big Canyons. No gold was found in panned-concentrate or stream-sediment samples taken north of Reilly Canyon or south of Big Canyon. For purposes of this report, the Goshute Canyon vein system is inferred to have a northern limit of Reilly Canyon and a southern limit of Big Canyon.

In an attempt to determine the continuity of the gold concentrations along what appears to be the major structure exposed in the Oro del Rey workings and Evelyn mine, four samples were taken from fracture zones about $1 / 2 \mathrm{mi}$ north of the Oro del Rey workings and $1 / 2 \mathrm{mi}$ south of the Evelyn mine. Two samples were from fracture zones between the Oro del Rey workings and Eagles Nest mine and two were from fracture zones present in the topographic high point between Goshute and Big Canyons. None of these samples contained detectable gold. Because of the difficulty in tracing these fracture zones, they may not be the same structures present in the Oro del Rey workings and Evelyn mine; if they are, they have no concentrations of metals at this locality. Indicated resource calculations for individual workings and an inferred resource calculation for the entire vein system follow.

\section{Eagles Nest Mine}

The Eagles Nest mine and related workings are the northernmost of the Goshute Canyon area mine workings and consist of the Eagles Nest mine, an unnamed shaft $850 \mathrm{ft}$ south of the mine, and a prospect pit about $100 \mathrm{ft}$ north of the mine. A quartz vein, similar to those at Goshute Canyon but dipping to the west, is present in the mine and workings. Between the mine and the unnamed shaft, the vein is displaced by east-trending faults and covered in places by colluvium. Thirteen of the fourteen samples taken from this vein contained gold. The vein is exposed for $80 \mathrm{ft}$ along strike and $110 \mathrm{ft}$ downdip in the Eagles Nest mine; for $45 \mathrm{ft}$ downdip in the unnamed shaft; in the prospect pit; and intermittently in outcrop for about $650 \mathrm{ft}$ along strike. Samples from the vein had a weighted average concentration of $0.25 \mathrm{oz}$ gold/st across an average vein width of 41 in. Assuming continuity of the gold concentration along the vein to the unnamed shaft and to the prospect pit, and a tonnage factor of $12.5 \mathrm{ft}^{3} / \mathrm{st}$, there is an indicated resource of 290,000 st of $0.25 \mathrm{oz}$ gold/st. This resource has an in-place value of $\$ 32$ million using a gold price of $\$ 450 \%$ oz.

\section{Oro del Rey Worklngs}

The Oro del Rey workings are about 1 mi south of the Eagles Nest mine area and consist of the Oro del Rey and Upper Oro del Rey adits, the Card Wonder (caved) and the Upper Card Wonder adits, the Water Winze decline, the Cliff adit, the Lehmer Crosscut adit, the Tripp adit, the Hickok (caved) and Upper Hickok adits, and the Devils Pit adits (fig. 3). A quartz vein is present in and between the workings. All 46 samples taken along this vein contained gold. The vein is exposed in the workings for $1,380 \mathrm{ft}$ along strike and $355 \mathrm{ft}$ downdip and in outcrop for about $1,600 \mathrm{ft}$ along strike and $400 \mathrm{ft}$ downdip between the workings. Indicated resources are present at the following workings: 5,400 st of $0.4 \mathrm{oz}$ gold/st in the Oro del Rey and Upper Oro del Rey adits; 4,600 st of $0.6 \mathrm{oz}$ gold /st in the Upper Card Wonder adit; 5,200 st of $0.6 \mathrm{oz}$ gold/st in the Water Winze and Cliff workings; $12,000 \mathrm{st}$ of $0.4 \mathrm{oz}$ gold/st in the Lehmer Crosscut adit; 13,000 st of $0.3 \mathrm{oz}$ gold/st in the Tripp adit; $800 \mathrm{st}$ of $0.7 \mathrm{oz}$ gold/st in the Upper Hickok adit; and 5,800 st of $0.6 \mathrm{oz}$ gold/st in the Devils Pit adit.

Samples taken from the vein exposed in the Oro del Rey workings had a weighted average concentration of $0.5 \mathrm{oz}$ gold/st across an average width of $24 \mathrm{in.} \mathrm{(inch).}$ Assuming continuity of the gold concentration along the 
vein between the workings and a tonnage factor of $\mathbf{1 2 . 5}$ $\mathrm{ft}^{3} / \mathrm{st}$, an indicated resource of $450,000 \mathrm{st}$ of $0.5 \mathrm{oz}$ gold $/ \mathrm{st}$ is defined for the part of the vein system in and between the Oro del Rey workings. This resource has an in-place value of $\$ 100$ million, using a gold price of $\$ 450 / \mathrm{oz}$.

One chip sample was taken from the vein where it crops out on a ridge between the Devils Pit and the Upper Hickok adits. This sample contains 475 ppb gold and has slightly high concentrations of lead and zinc. Although the gold concentration is not as high as that of the samples taken from the workings, it indicates that base- and precious-metal concentrations are continuous along the vein.

\section{Evelyn Mine}

The Evelyn mine is about $1 / 2 \mathrm{mi}$ south of the Oro del Rey workings and consists of the Evelyn mine (a 600-ft-long tunnel and an 800-ft-long adit) and an unnamed adit about $300 \mathrm{ft}$ south of the mine. Two quartz veins are exposed in and between the workings.

One vein is exposed for $1,020 \mathrm{ft}$ along strike and $140 \mathrm{ft}$ downdip in the tunnel, in the unnamed prospect adit, and between these two workings. Samples from the vein had a weighted average concentration of $0.75 \mathrm{oz}$ gold/st across an average width of 11 in. Assuming continuity of the gold concentration along the vein and a tonnage factor of $12.5 \mathrm{ft}^{3} / \mathrm{st}$, there is an indicated resource of 34,000 st of $0.75 \mathrm{oz} \mathrm{gold} / \mathrm{st}$. This resource has an in-place value of $\$ 11$ million, using a gold price of $\$ 450$ per ounce.

A second vein is exposed underground in the 800 -ft-long adit for $380 \mathrm{ft}$ along strike where it pinches out against a thin fracture zone, which continues for about $390 \mathrm{ft}$ to the face. This vein is also exposed updip in a manway and ore chute, which were inaccessible for sampling at the time of this study. Samples from the vein had a weighted average concentration of $0.015 \mathrm{oz}$ gold/st across an average width of $20 \mathrm{in}$. The low grade of the gold concentration along this narrow a structure does not warrant calculating a resource.

\section{Adits in Goshute Canyon}

The mine workings in Goshute Canyon consist of the Bueno adit, an unnamed adit about $150 \mathrm{ft}$ south of the Bueno adit, and the adits in lower Goshute Canyon. A quartz vein is present in, and extends between, the Bueno adit and the unnamed adit to the south; another quartz vein is exposed in the adits in lower Goshute Canyon. The vein exposed in the Bueno adit and the unnamed adit to the south contains gold ranging from $<5 \mathrm{ppb}$ to $0.098 \mathrm{oz} / \mathrm{st}$. The average grade of the material sampled is not high enough to warrant calculating a resource. Thin veins, exposed in the adits in lower Goshute Canyon, had sporadically distributed concentrations of gold ranging from $<5 \mathrm{ppb}$ to 0.842 $\mathrm{oz} / \mathrm{st}$. When diluted across any conceivable mining width, the concentrations of gold would be greatly reduced. The distribution of gold is too sporadic to warrant the calculation of a resource at this site.

\section{Sliver Queen Property}

The Silver Queen property is about $1 \frac{1 / 2}{2}$ mi east of the Evelyn mine. Workings in this area consist of an adit, three shafts, two caved adits, and one prospect pit. The country rock is quartzite and shale. No mineralized structures were observed in any of the workings at this location. One select sample of material from the dump of a plugged shaft had concentrations of $3,200 \mathrm{ppb}(0.093$ oz/st) gold, $36.7 \mathrm{oz}$ silver $/ \mathrm{st}, 4,040 \mathrm{ppm}$ copper, $13 \mathrm{ppm}$ molybdenum, 44,200 ppm lead, $130 \mathrm{ppm}$ tungsten, and 1,425 zinc. None of this material was seen in place and it did not resemble any of the other dump material examined. The other seven grab and select samples taken from these workings contained gold, $<5-45 \mathrm{ppb}$; silver, 0.5-70 ppm; copper, 10-446 ppm; molybdenum, <1-20 ppm; lead, 40-2,750 ppm; zinc, 12-359 ppm; and sporadic traces of bismuth and beryllium. These concentrations are not high enough to indicate the presence of a resource at this site.

\section{Miscellaneous}

To determine if gold concentrations were present in the host rock, 25 samples of quartzite were taken from the hanging walls and footwalls of the veins exposed in the workings in the Goshute Canyon mineralized area. In general, gold concentrations decrease sharply within $2 \mathrm{ft}$ of the veins in this area. Two samples taken in the Evelyn mine within $2 \mathrm{ft}$ of the vein contained 3,400 and $1,000 \mathrm{ppb}$ $(0.099$ and $0.029 \mathrm{oz} / \mathrm{st})$ gold, and two samples taken from between vein splits in the adits in lower Goshute Canyon contained 510 and $800 \mathrm{ppb}$ gold. Samples taken further from the veins have gold concentrations of $<5-190 \mathrm{ppb}$.

Three samples were taken of a weathered intrusive present in the Evelyn mine and Devils Pit adits. These samples contain from less than $5 \mathrm{ppb}$ to $290 \mathrm{ppb}$ gold. The concentrations of gold present in the intrusives is not great enough to be considered a resource.

\section{Economic Evaluation}

The Goshute Canyon area has an indicated gold resource of 774,000 st of vein material at a weighted average concentration of $0.4 \mathrm{oz}$ gold/st. This resource consists of 290,000 st of $0.25 \mathrm{oz}$ gold $/ \mathrm{st}$ at the Eagles Nest mine; $450,000 \mathrm{st}$ of $0.5 \mathrm{oz}$ gold/st at the Oro del Rey workings; and 34,000 st of $0.75 \mathrm{oz}$ gold/st at the Evelyn mine. This indicated resource totals about $300,000 \mathrm{oz}$ gold valued at $\$ 143$ million using a price of $\$ 450 / \mathrm{oz}$ gold. 
If gold concentration and vein thickness are consistent throughout the vein system and between the workings, an inferred resource of 5.7 million st of $0.4 \mathrm{oz} / \mathrm{st}$ is present. The indicated and inferred resources total 2.3 million oz gold valued at $\$ 1$ billion using a price of $\$ 450 / 0 z$ gold.

For costing purposes, we assume that the deposit would be mined using shrinkage stoping and a 3-ft stope width. Although this method is labor intensive and therefore costly, the thickness of the vein does not lend itself to other mining methods. The U.S. Bureau of Mines MINSIM 09 evaluation program, a computerized cash-flow analysis program, was run assuming a mining rate of 200 st per day and four different rates of return. A hypothetical mine would break even with the price of gold at $\$ 344 / \mathrm{oz}$; have a 5 -percent rate of return at $\$ 378 / \mathrm{oz}$; 10 -percent at $\$ 426 / \mathrm{oz}$; and 15 -percent at $\$ 478 / \mathrm{oz}$. The gold resource in the Goshute Canyon area is similar in type and grade to the Courthouse vein system in Colorado. The Courthouse system is a narrow veintype gold deposit consisting of 4 million tons of vein material containing 0.4 ounces gold per ton and has been studied in detail by the USBM (Scott, 1986). A company skilled at efficient mining of narrow vein deposits probably could develop this resource profitably at current prices. Hypothetically, this deposit is marginally economic (Scott, 1986).

In addition to gold, concentrations of silver, copper, lead, molybdenum, tungsten, and zinc are sporadically distributed in the vein samples taken throughout the Goshute Canyon area. These concentrations are too low and sporadically distributed to be considered a resource in and of themselves, but the minerals might be recovered as byproducts.

Drilling would be necessary to completely delineate the dimension and grade of the material present along the structures in the Goshute Canyon area. Detailed surface mapping and sampling of the veins in the Goshute Canyon area might substantially increase the size of the identified resources.

\section{Queen of Sheba Mine}

The Queen of Sheba mine area is on a block of patented claims $16 \mathrm{mi}$ south of Ibapah about 1 mi outside the Deep Creek Mountains Wilderness Study Area boundary and is surrounded by the Goshute Indian Reservation. The largest working in the area is known as the Queen of Sheba mine and is accessible by the Martin and Johnson adits. A smaller working is about $200 \mathrm{ft}$ north and is accessible by the Queen adit. In this report, this smaller working will be referred to as the "Old Queen of Sheba mine." Four other adits once open to these workings were caved at the time of this study. Other workings on the nearby Goshute Indian Reservation were not examined because permission to sample on the reservation was not obtained.
The structures in the Queen of Sheba mine and the Old Queen of Sheba mine are fracture zones in the Unit B quartzite of the Late Proterozoic McCoy Creek Group. Granitic rock is present in the lower level of the Queen of Sheba mine, and its emplacement appears to have caused the quartzite to fracture. A major fracture zone ranges from 1 to $20 \mathrm{ft}$ wide, strikes east to northeast, and dips to the south. It is cut by a zone of fractures that are from 1 to $4 \mathrm{ft}$ wide, strike north, and have varying degrees and directions of dip. Both zones contain fractured and altered quartzite, sparsely disseminated galena, malachite, limonite, and gouge. Some fractures are filled with stringers of highly altered granitic intrusive. The fracture zones weather easily and cannot be traced along the surface past the extent of the workings.

In the Queen of Sheba and the Old Queen of Sheba mines, most of the drifting and stoping was done on the main fracture zone. Sixteen of the eighteen samples taken along this structure contain gold. The main fracture zone is exposed for about $800 \mathrm{ft}$ along strike and about $250 \mathrm{ft}$ downdip. Samples from the zone had a weighted average concentration of $0.22 \mathrm{oz}$ gold/st across an average width of 35 in. There is an indicated resource of 75,000 st of $0.22 \mathrm{oz}$ gold/st present along the main structure. This resource totals at least $16,000 \mathrm{oz}$ gold. Additional exploration work, especially drilling, would probably define a larger resource at this site. The grade of the material present at this location does not warrant an economic evaluation.

Gold is present in the wall rock immediately surrounding the structure. Fourteen samples of the fractured quartzite wall rock were taken, nine of which had gold concentrations ranging from 0.002 to $0.06 \mathrm{oz} / \mathrm{st}$. Gold concentrations range from 0.012 to $0.06 \mathrm{oz} / \mathrm{st}$ in samples taken $20 \mathrm{ft}$ from the structure, but only trace amounts of gold were present in samples taken $20-100 \mathrm{ft}$ from the structure. More detailed sampling of the mineralized rock immediately surrounding the structure is necessary to determine if a gold resource is present in this material.

Ten samples were taken from the altered granite intrusive, of which two had gold concentrations of $\mathbf{0 . 1 2}$ and $0.006 \mathrm{oz} / \mathrm{st}$. The gold is too sporadically distributed and the concentrations are too low to indicate the presence of a resource.

Concentrations of silver, copper, lead, molybdenum, tungsten, and zinc are also present in samples taken from the major structure, from minor structures, and from the country rock. These concentrations are too low and sporadically distributed to be considered a resource.

The claim owner reports that the granite intrusive exposed in the lower levels of the Queen of Sheba contains tin (Alan Fishler, Queen of Sheba Mining Co., oral commun., July, 1986). Ten samples of the intrusive 
taken during the present study were analyzed for tin. No tin was present in the rock samples, but two pannedconcentrate stream samples taken downstream from the mines contained $15 \mathrm{ppm}$ and $53 \mathrm{ppm}$ tin. A more detailed sampling of the intrusive is required to determine if tin is present and in what concentrations.

\section{Red Mountain Area}

Red Mountain consists mostly of heavily ironstained quartzite of unit B of the Late Proterozoic McCoy Creek Group and is about 1 mi east of the Queen of Sheba mine. Finely disseminated sulfides and limonite pseudomorphs after pyrite are sparse throughout the quartzite. Grab and chip samples from Red Mountain were taken and analyzed to determine if they contained gold or pathfinder elements for gold in an attempt to ascertain if this is an extension of the gold mineralization found in the Queen of Sheba mine.

Nineteen samples were taken from the quartzite, altered limestone, schist, and a granite dike found on Red Mountain. None of these samples contain detectable gold. Minor concentrations of pathfinder elements such as bismuth, copper, lead, molybdenum, tungsten, and zinc are present in some samples taken from Red Mountain, but are too low and sporadically distributed to be a conclusive indication of gold concentrations comparable to those in the Queen of Sheba mine. However, the samples taken at the lowest elevations from Red Mountain were taken at $10,300 \mathrm{ft}, 1,000 \mathrm{ft}$ higher than the elevation of the Queen of Sheba mine. Mineralizing fluids may not have contained gold this high up into the system. Drilling would be required to ascertain if concentrations of gold are present at depth under Red Mountain. No resource can be defined at this location at this time.

\section{Gold Bond Area}

The Gold Bond area is just outside the eastern boundary of the Deep Creek Mountains Wilderness Study Area and contains 1- to 4-ft-wide mineralized fracture zones in the quartzite of unit 3 of the Late Proterozoic Trout Creek sequence. These zones are exposed in five adits, one caved adit, one inclined shaft (the Inclined Shaft mine), one shaft, and three prospect pits. The zones strike northeast and northwest and have varying degrees and directions of dip. Limonite gouge and fractured and altered host rock occur along the fractures. A quartz vein in the fracture zone exposed in the Inclined Shaft contains pyrrhotite, pyrite, hematite, malachite, and chrysocolla. These fracture zones weather easily and most cannot be traced along the surface past the workings.

The most mineralized structure in this area is exposed in the Inclined Shaft. Gold is present in all 21 chip samples taken from a 6- to 36-in.-wide quartz vein along a fracture. The vein also contains sporadically distributed and minor concentrations of bismuth, copper, lead, molybdenum, silver, tungsten, and zinc. The vein is exposed for about $65 \mathrm{ft}$ along strike and about $170 \mathrm{ft}$ downdip. Samples from the vein had a weighted average concentration of $0.26 \mathrm{oz}$ gold/st across an average width of 15 in. Assuming continuity of the gold concentration along the vein and a tonnage factor of $12.5 \mathrm{ft}^{3} / \mathrm{st}$, there is an inferred resource of 3,800 st of $0.26 \mathrm{oz}$ gold/st present at the mine. This resource totals a minimum of $980 \mathrm{oz}$ gold. Additional exploration work, especially drilling might define a larger resource at this site. The amount and grade of the material present here does not warrant an economic evaluation.

Four samples of quartzite were taken from the footwall and hanging wall of the vein in the Inclined Shaft to determine if gold is present in the surrounding wall rock. These samples contain traces of gold, lead, and zinc, but concentrations of these elements are too low to indicate the presence of a resource.

One hundred-two chip and grab samples were taken from fracture zones and country rock exposed in the accessible adits and prospect pits, the dump of a caved adit, an inaccessible shaft, and two sloughed-in prospect pits in the area. The fractures are not extensive and the few base- and precious-metal-bearing minerals observed are sparse throughout. Although minor concentrations of bismuth, copper, gold, lead, molybdenum, silver, tungsten, and zinc are found in some samples taken from these fractures, the concentrations are not high or consistent enough to define a resource at these localities.

\section{Trout Creek Area}

The Trout Creek area is just outside the Deep Creek Mountains Wilderness Study Area boundary and about $12 \mathrm{mi}$ southwest of Callao. Fracture zones in shattered dolomite and schist of units 1-3 of the Late Proterozoic Trout Creek sequence were mineralized surrounding Cretaceous or Tertiary alaskite intrusive at Trout Creek. Wall-rock composition seems to have had little control on mineral deposition along these fractures. These fracture zones, exposed in 4 adits, 2 caved adits, 5 declines, 5 shafts, and 28 prospect pits, have no common strike or dip and range in width from 3 to $30 \mathrm{ft}$. Some zones contain only minor gouge, but others are highly altered and contain quartz, muscovite, fluorite, scheelite, and beryl. These zones are generally discontinuous because the rock is faulted and shattered.

The most highly mineralized material in the Trout Creek area is exposed in the Trout Creek mine. Two veins are exposed in this mine. The principal vein is accessible along the drift for $\mathbf{1 3 0} \mathrm{ft}$ and downdip for 
$200 \mathrm{ft}$ in a winze. In the winze, the vein is exposed downdip; the winze is inaccessible, however. A secondary vein is exposed along strike for $80 \mathrm{ft}$ near the face. In these veins, scheelite and sphalerite are associated with quartz, muscovite, fluorite, and beryl in dolomite. Thirty samples of vein material contain beryllium, bismuth, cadmium, copper, gold, lead, molybdenum, silver, tungsten, and zinc. At 1990's prices, only the tungsten and zinc concentrations are high enough to justify calculating their average grade along the vein. Samples from both veins have a weighted average concentration of about $800 \mathrm{ppm}$ tungsten and 2.5 percent zinc across an average width of 3 to $4 \mathrm{ft}$. Concentrations of these metals would have to be considerably higher to counter the expense of mining and milling a vein-type deposit such as this.

The Trout Creek area has been extensively prospected for tungsten and beryllium. In 1961 and 1962, the Western Beryllium Co. drilled nine 70- to 270-ft-deep holes in an attempt to identify resources of beryllium and tungsten. The highest concentrations of beryllium and tungsten in the drill holes were 0.16 percent and 0.5 percent, respectively. Most of the samples contained considerably less beryllium and tungsten than this and generally contained from 0.02 to 0.08 percent beryllium and from 0.1 to 0.25 percent $\mathrm{WO}_{3}$. Complete sample data are presented by Thomson (1973). The low concentrations of beryllium and tungsten in these samples do not indicate the presence of a resource.

Samples taken from the other workings in the Trout Creek mine area contain beryllium, bismuth, cadmium, copper, gold, lead, molybdenum, silver, tungsten, and zinc, but these metals are not present in high enough concentrations to indicate the presence of a resource. Maps of the workings and detailed sample information are presented in Hannigan (1990).

\section{Singleton Canyon Area}

The Singleton Canyon area is $1 \mathrm{mi}$ outside the Deep Creek Mountains Wilderness Study Area boundary and about $23 \mathrm{mi}$ south of Ibapah. Here, quartzite of unit D of the Late Proterozoic McCoy Creek Group contains mineralized fracture zones. These fracture zones, which are filled by pods and lenses of secondary quartz, gouge, limonite, and sparse disseminated sulfides, are exposed in the Singleton Canyon adit, a shaft, a prospect adit, and four prospect pits. These zones generally strike northwest, dip to the northeast, and are discontinuous; they cannot be traced along the surface outside the workings. In a fifth pit, no structure was observed, but the material present on the dump suggests that the mineral assemblage was similar to that in the other pits. These zones are mostly from 1 to $10 \mathrm{ft}$ wide and are exposed along strike for no more than $20 \mathrm{ft}$.
A select sample of the most visibly mineralized material from the dump of a shaft sunk on one of these fracture zones contained $50 \mathrm{ppb}$ gold, $220 \mathrm{ppm}$ silver, 4.00 percent copper, 1.13 percent lead, 144 ppm zinc, $1,160 \mathrm{ppm}$ bismuth, and $510 \mathrm{ppm}$ tungsten. Chip samples from other zones had lower concentrations of these metals. Select samples of carbonate rock and of an altered granitic dike from the dump of the shaft had slightly higher concentrations of metals.

Twenty-five chip samples of fractured quartzite with secondary quartz and minor limonite and gouge along fracture planes were taken from the Singleton Canyon adit. Three samples contained from 85 to 250 ppb gold. One sample contained $50 \mathrm{ppm}$ silver, 3,500 ppm copper, and 4,800 ppm lead; another contained $6,697 \mathrm{ppm}$ zinc. The other samples from this working had considerably lower concentrations of base and precious metals.

The fracture zones in the Singleton Canyon area contain low concentrations of base and precious metals sporadically distributed along the discontinuous structures. The low concentrations and sporadic distribution of metals along these structures and the discontinuity of the structures preclude them from being considered a resource.

\section{Miscellaneous}

Radioactive minerals have been reported in heavymineral concentrates within range-front alluvial fans near the mouth of Trout Creek. Uranium and thorium in monazite, sphene, zircon, and allanite in these gravels reportedly range from 20 to $170 \mathrm{ppm}$ and from 100 to $850 \mathrm{ppm}$, respectively (U.S. Geological Survey, 1979). Alluvial fans are outside the study area and no evidence of concentration of radioactive minerals was found anywhere in the study area during the course of the present investigation.

An adit driven on an 18-ft-wide breccia zone in quartzite is about 2,500 ft east of Abercrombie Peak. The zone consists of fractured quartzite sparsely cemented with silica and calcite and contains minor limonite. Four of seven samples taken contained gold, and one sample contained zinc, but these concentrations are too low to indicate the presence of a resource at this site.

An adit and a shaft on the south side of Chokecherry Canyon were driven on a 0.3 - to 3-ft-wide fracture zone in limestone. A vein of galena, calcite, limonite, and hematite has been emplaced along this zone. The vein pinches and swells (about 4-12 in. wide) and cannot be traced past the workings because it is covered with colluvium. Seven samples were taken from this fracture zone and vein, and one sample was taken of brecciated limestone next to the vein. These samples contained copper, gold, lead, silver, and zinc. Although 
lead concentrations ranged from $45 \mathrm{ppm}$ to 23.4 percent, the narrow, discontinuous, and irregular character of the vein precludes the definition of a resource at this locality.

Beryl was reported in pegmatite dikes in the Ibapah pluton and in gulch gravels near Ibapah Peak (Dasch, 1964; Hilpert, 1964). Two samples of granite of the Ibapah pluton and panned-concentrate and streamsediment samples from the stream gravels were taken and analyzed. The samples contained no beryllium. If beryllium is present, as suggested by the literature, concentrations of beryllium should have been found in the panned-concentrate and stream-sediment samples. No resource is defined in the Ibapah pluton.

An adit was driven on a thin fracture zone in schist in Horse Canyon. Five chip samples taken along this zone contained gold, <5-115 ppb; silver, 0.5-1 ppm; copper, 10-56 ppm; lead, 25-190 ppm; and zinc, 173-587 ppm. The low concentrations of base and precious metals in the samples do not indicate the presence of a resource at this site.

\section{Drainage Sampling Results}

Panned-concentrate and stream-sediment samples were taken from Deep Creek Mountains Wilderness Study Area drainages in an attempt to delineate the extent of known mineralized material found in the workings. Forty-one panned-concentrate and 83 streamsediment samples were taken in and near the study area. Complete sample information is shown in Hannigan (1990). Concentrations of metals in samples downstream from a known working or habitation are assumed to have been derived from the mineralized material present or contamination from mining and other human activities at those workings. Concentrations of metals in samples upstream from or in adjacent drainages to known workings or habitations are assumed to indicate either an extension or associated occurrence of the mineralized material present in the workings or the existence of another mineralized area.

\section{Panned-Concentrate Samples}

Gold was present in notable concentrations in four panned-concentrate samples taken from drainages downstream from the Goshute Canyon and Queen of Sheba workings and from a drainage on the east side of Red Mountain.

Concentrations of mercury greater than $200 \mathrm{ppm}$ were detected in four samples. These samples were taken below the Cougar Hill workings, upstream and downstream from the Goshute Canyon workings, and downstream from the Queen of Sheba workings. Two samples contained 1,145 and 4,100 ppm lead. These samples were taken upstream from the Goshute Canyon workings and downstream from the Queen of Sheba workings.

Tin was present in 14 samples. One of these samples was taken downstream from the Goshute Canyon workings, 11 were taken from streams draining the Ibapah pluton, and 2 were taken downstream from the Queen of Sheba workings.

Concentrations of $9 \mathrm{ppm}$ molybdenum and $50 \mathrm{ppm}$ tungsten were found in one sample, and $2,310 \mathrm{ppm}$ tungsten was found in another. Both samples were taken from tributaries to Trout Creek.

\section{Stream-Sediment Samples}

Gold was present in concentrations greater than 10 ppb in two samples. These samples were taken in Hardscrabble Canyon and from a drainage below the Queen of Sheba mine.

Concentrations of mercury of $120 \mathrm{ppm}$ or greater were detected in seven samples. Three of these samples were taken below the Cougar Hill workings, one was taken upstream from the Goshute Canyon workings, and three were from drainages on the south side of Red Mountain.

Concentrations of tungsten were found in four samples. Samples were taken downstream from the Gold Bond workings from a tributary to Trout Creek on the south side of Red Mountain, from the Trout Creek mining area, and upstream from the Trout Creek mining area.

\section{Interpretation}

The panned-concentrate sample containing gold taken on the east side of Red Mountain and the streamsediment samples containing mercury taken on the south side of Red Mountain indicate that mineralized rock, perhaps similar to that exposed in the Queen of Sheba mine, exists in the Red Mountain area.

The gold present in the stream-sediment sample taken in Hardscrabble Canyon, the mercury found in the panned-concentrate and the stream-sediment samples, and lead in the panned-concentrate sample taken in Goshute Canyon upstream from the workings are evidence of extensions of deposits or of related deposits west and northwest of the deposits exposed in the Goshute Canyon area.

The panned-concentrate samples taken from the Ibapah pluton indicate that the pluton contains trace amounts of tin. It is not unusual for this rock type to contain tin, and, therefore, the tin anomalies are not by themselves considered to indicate the presence of tin resources in the Ibapah pluton.

The concentrations of tungsten and molybdenum found in the tributaries to Trout Creek indicate 
extensions or related occurrences of the tungstenbearing structures present in the Apex and Trout Creek mines.

\section{Industrial Rocks and Minerals}

Rocks in the Deep Creek Mountains Wilderness Study Area were examined to ascertain if they were valuable for industrial or construction uses. Limestone, dolomite, and quartzite units were examined and sampled. The possibility of sand and gravel deposits in the area was also investigated.

\section{Limestone and Dolomite}

The suitability of the limestones and dolomites in and near the study area was evaluated for chemical and agricultural uses. Nineteen chip samples of limestone and dolomite were taken from outcrops and analyzed to determine their purity. Although calcium carbonate and magnesium carbonate contents are generally too low to be of any value for chemical uses, four of these samples are within the standard specifications for agricultural uses (Bates, 1969). Vast quantities of this limestone crop out in the northern one-third of the Deep Creek Range.

Even though vast amounts of limestone suitable for agricultural uses are present in the study area, the following factors limit its development for all but local use: high bulk, low unit value, and the high transportation cost resulting from the remoteness of the area. Local demand for limestone and dolomite is limited to nonexistent.

\section{Quartzite}

The suitability of the quartzites in and near the study area for use in the manufacture of glass was evaluated. Nineteen chip and grab samples of quartzite from the Busby and Prospect Mountain Quartzites and from quartzites of the McCoy Creek Group and the Trout Creek sequence were taken from workings and outcrops. These samples were analyzed to determine their purity. Ten of these samples are within the suggested specifications for making eighth- or ninthquality amber glass (Buie and Robinson, 1958). Vast tonnages of this material are present both in and near the study area. The most accessible material is present along the eastern side of the northern one-third of the range just outside the study area.

Even though vast quantities of quartzite suitable for production of low-quality glass is present in and near the study area, the following factors limit its development for all but local use: high bulk, low unit value, high transportation cost resulting from the remoteness of the area, and the cost of processing quartzite for use in making glass. There is no local demand for quartzite.

\section{Sand and Gravel}

Sand and gravel deposits occur along the flanks of the Deep Creek Range outside the study area, but the steep, narrow valleys of the range are not suitable for the accumulation of these gravel deposits. No sand and gravel resource was defined within the study area.

\section{ASSESSMENT OF POTENTIAL FOR UNDISCOVERED RESOURCES}

\author{
By Constance J. Nutt, \\ David R. Zimbelman, \\ David L. Campbell, and Joseph S. Duval \\ U.S. Geological Survey
}

\section{Geology}

\section{Previous Work}

Maps and descriptions by Bick (1966), Nelson (1966), and Rodgers $(1987,1989)$ include all or most of the Deep Creek Mountains Wilderness Study Area. Butler and others (1920) discussed ore deposits in the Deep Creek Range. A study of the Gold Hill mining district by Nolan (1935) includes the northern part of the study area. McCollum and McCollum (1984) applied regional stratigraphy in their study of the northern Deep Creek Range. Wallace (1986) studied the Ibapah pluton and shear zones that cut it. Thomson (1973) described ore deposits in the Deep Creek Range, and Cadigan and others (1979) evaluated part of the study area for uranium and thorium potential.

Unless otherwise noted, the description of the geologic setting and structure is from Rodgers (1987, 1989).

\section{Geologic Setting and Structure}

The Deep Creek Mountains Wilderness Study Area is in the eastern Great Basin, an area characterized by north-trending ranges separated by alluvium-filled basins. The study area includes most of the Deep Creek Range, which is a west-tilted block of Late Proterozoic to Permian strata cut by Cretaceous(?) and Tertiary intrusive rocks and, at the southern end of the range, overlain by Tertiary volcanic rocks. North of the study area and near Gold Hill, Jurassic and Tertiary stocks 
crop out (Nolan, 1935; Stacey and Zartman, 1978). The Eocene Ibapah pluton underlies the central part of the study area and separates primarily Late Proterozoic deformed metamorphic rocks to the south from mostly little-deformed Paleozoic sedimentary rocks to the north (pl. 1).

The Late Proterozoic and Paleozoic rocks comprise a clastic and carbonate sequence about 35,000 $\mathrm{ft}$ thick that was deposited in a broad marine shelf along the western coast of North America. The Late Proterozoic sequence of chlorite- to garnet-grade schist, quartzite, metadiamictite, phyllite, metasiltstone, and marble is mostly exposed in the southern part of the range and the southern part of the study area. About 4,000 feet of Lower Cambrian quartzite and subordinate shale overlie the Late Proterozoic rocks and crop out in the southern part of the study area and the eastern cliffs of the northern part of the study area. The predominantly Late Proterozoic to Lower Cambrian clastic sequence is overlain by about $11,000 \mathrm{ft}$ of Middle Cambrian to Pennsylvanian limestone, dolomitized limestone, dolomite, and subordinate shale, siltstone, and sandstone that makes up most of the northern part of the study area. The carbonate rocks range from thin-bedded to massive and are in places argillaceous. Parts of this predominantly carbonate sequence are also exposed in other ranges in west-central Utah (Hintze, 1988).

The Eocene Ibapah pluton underlies the high peaks and scenic valleys in the central part of the range. An aeromagnetic profile, discussed in the "Geophysics" section, suggests that the pluton is rootless and is offset near its northern border. The 39-Ma pluton is a monzogranite to granodiorite (Wallace, 1986) that shows surprisingly little compositional variation. The rock is coarse grained and consists primarily of quartz, potassium feldspar, plagioclase, biotite, secondary chlorite, and, in places, muscovite. Accessory phases include allanite, sphene, zircon, apatite, monazite, and thorite; thorite was detected during our study. Wallace (1986) documented a large sheared area in the eastern part of the pluton and hematite-altered rocks in the northcentral part. Along the eastern range front, the monzogranite is chloritized and silicified (Wallace, 1986).

Small bodies of garnet-bearing alaskite are exposed immediately outside the study area in the Queen of Sheba mine on the western side and in the Trout Creek area on the eastern side of the range. The rocks are texturally different and may be unrelated and of different ages. The largest body, on the east side of the range, is coarse-grained alaskite composed primarily of quartz, potassium feldspar, muscovite, garnet, and, locally, biotite. Our mapping indicates that alaskite occurs as sills, and along its contacts is commonly foliated and interleaved with foliated biotite schist. Rodgers (1987) interpreted an ${ }^{40} \mathrm{Ar} /{ }^{39} \mathrm{Ar}$ age of about $27 \mathrm{Ma}$ from muscovite and feldspar grains as a cooling age associated with uplift and proposed a Cretaceous age for the alaskite. Doming of metasedimentary rocks as far as 3.5 miles from exposed alaskite and a less widespread contact aureole suggest that unexposed alaskite underlies metasedimentary rocks in part of the study area near Trout Creek. On the western side of the range, fine-grained, garnet-bearing alaskite crops out only as dikes and in the underground workings of the Queen of Sheba mine. The rock has no discernable metamorphic texture.

Rocks in the eastern Great Basin have been extensively deformed. During the Sevier orogeny in Mesozoic time, the rocks in the study area were folded and thrust in an easterly direction and, at depth, metamorphosed. Folded and metamorphosed rocks in the southern part of the study area represent a deep level of deformation and metamorphism. The Birch Canyon fault in the southern part of the study area and the Rocky Spring thrust in the northern part of the area are probably Mesozoic structures. In addition, difficult to recognize Sevier(?)-age, younger over older faults that thin units in ranges to the east (Hintze, 1978; Nutt and others, in press) may displace rocks in the Deep Creek Range.

During the Tertiary, the eastern Great Basin was extended along normal faults. The Deep Creek Range was uplifted and rotated in a westward direction along the Reilly Canyon fault on the east side of the range (see cross section in Rodgers, 1988). Rocks along this fault were extensively broken and sheared. In Snake Valley, to the east of the Reilly Canyon fault, a major range-front fault that apparently drops down rocks to the east is buried by alluvium. A buried fault that apparently drops down rocks to the west is inferred to be present in Deep Creek Valley on the west side of the range.

The contacts of the Ibapah pluton are about parallel to east-trending faults in the northern part of the range. The strike of these contacts suggests that emplacement of the pluton was controlled by deep easttrending faults that probably formed during Mesozoic time. The presence of fracturing and shearing along the northern contact of the Ibapah pluton (Bick, 1966; Robert A. Zimmermann, U.S. Geological Survey, oral commun., 1988) and the about east-trending shear zone in the Ibapah pluton suggest that these deep faults were reactivated during Tertiary time.

\section{Geochemistry}

\section{Introduction}

The USGS geochemical study provided data for the mineral resource potential assessment presented here. Complete sample analyses, sample localities, and description of sampling and analytical techniques can be 
obtained from David R. Zimbelman, U.S. Geological Survey, Box 25046, MS 973, Denver Federal Center, Denver, Colorado 80225.

Altered and mineralized rocks in the Deep Creek Range have a complex geochemical signature. Altered rocks from the northern part of the range, outside the study area, contain anomalous concentrations of many elements including gold, silver, arsenic, antimony, bismuth, molybdenum, lead, zinc, copper, fluorine, manganese, boron, barium, tungsten, beryllium, strontium, and titanium (Nolan, 1935; Griffitts, 1965). Ore deposits in this northern part of the range are predominantly veins, skarns, and carbonate-hosted replacements (Butler and others, 1920; Nolan, 1935; El-Shatoury and Whelan, 1970; Thomson, 1973). Some of these deposit types and metal anomalies also occur in the study area.

\section{Sample Collection}

Samples were collected in the spring and summer of 1986 and 1988. Sixty-eight minus-80-mesh streamsediment and 68 heavy-mineral concentrate samples were collected at the same sites from alluvium in the channels of first-order (unbranched) streams and second-order (below the junction of two first-order streams) streams as defined on USGS $71 / 2$-minute topographic maps. Fifty-five sample localities are shown on plate 1. Chemical analysis of sediments provides information for identification of those basins that have unusually high concentrations of elements and that may contain mineral occurrences. Analysis of the nonmagnetic fraction of heavy-mineral concentrates was the most useful geochemical method for the reconnaissance evaluation of the study area for all elements except gold. Concentrate samples generally contain minerals that form during alteration and (or) mineralization. In mineralized areas, concentrates may contain such minerals as pyrite $\left(\mathrm{FeS}_{2}\right)$, galena ( $\left.\mathrm{PbS}\right)$, cassiterite $\left(\mathrm{SnO}_{2}\right)$, sphalerite $(\mathrm{ZnS})$, barite $\left(\mathrm{BaSO}_{4}\right)$, scheelite $\left(\mathrm{CaWO}_{4}\right)$, and native gold. The selective concentration of ore minerals permits determination of some elements not easily detected by analysis of bulk stream sediments.

Rock samples were collected in and near the study area. Rocks that appeared unaltered were sampled for information on geochemical background concentrations. Visibly altered rocks were sampled at mines, prospects, and other places to determine suites of elements associated with mineralized and altered rock.

\section{Analytical Methods}

The samples were analyzed for 31 elements (table 1) using a semiquantitative, direct-current arc emission spectrographic method (Grimes and Marranzino, 1968).
Table 1. Limits of determination for the spectrographic analysis of rock and stream-sediment samples based on a 10-milligram sample, from in and near Deep Creek Mountains Wilderness Study Area

[The spectrographic limits of determination for heavy-mineral concentrate samples are based on a 5-milligram sample, and are therefore two reporting intervals higher than the limits given for rocks and stream sediments]

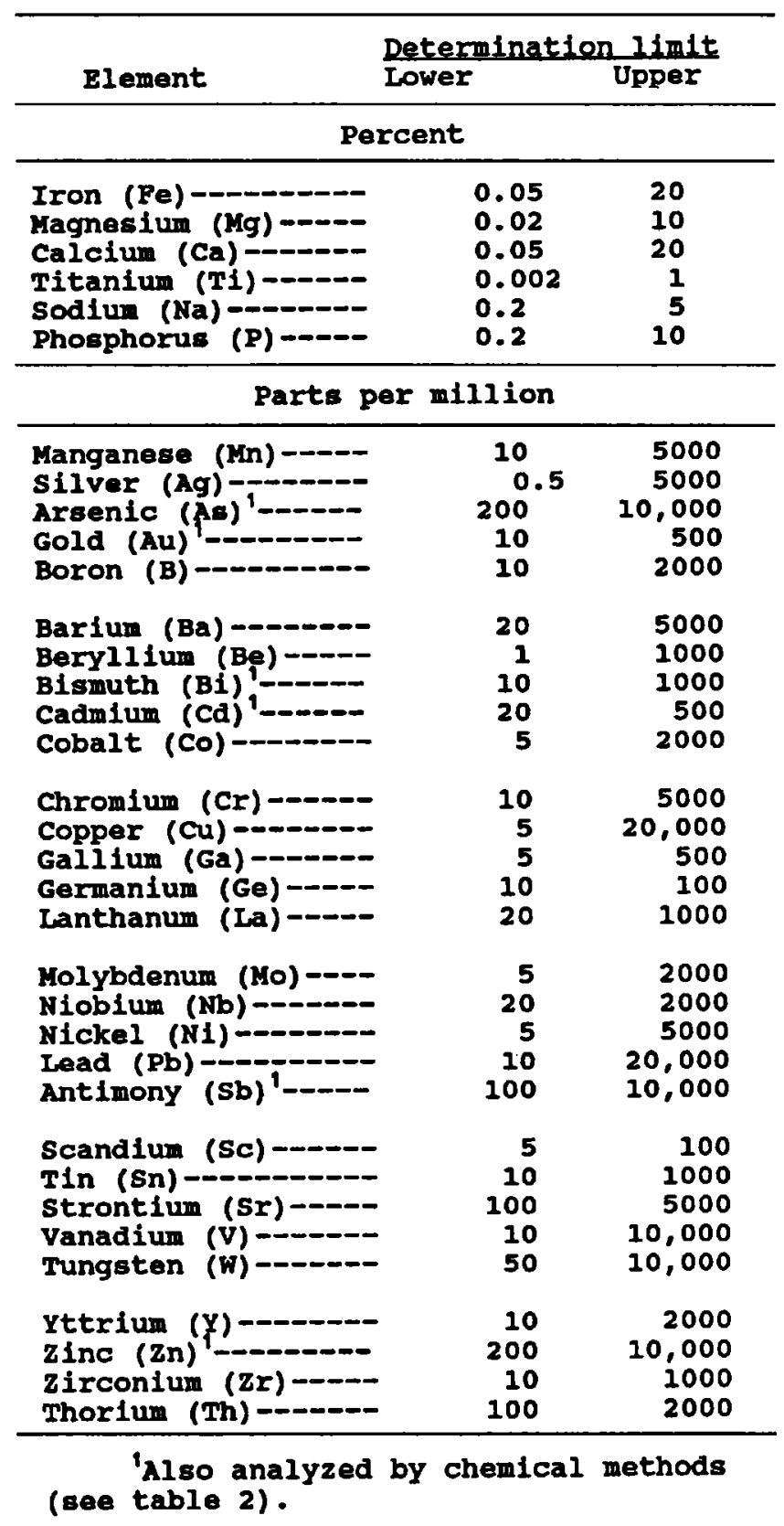

In addition, samples collected in 1988 were analyzed for four more elements (sodium, phosphorus, gallium, and germanium, table 1). Values determined for the major elements (iron, magnesium calcium, titanium, sodium, and phosphorous) are given in weight percent; all others are given in parts per million (ppm). Threshold values 
Table 2. Chemical methods used for analysis of selected elements, Deep Creek Mountains Wilderness Study Area

[AA, atomic absorption; AACV, atomic absorption cold vapor, ICP, inductively coupled argon plasma-atomic emission spectrographic; ISE, ion-selective electrode; Det. limit, determination limit, in parts per million (ppm)]

\begin{tabular}{|c|c|c|c|}
\hline $\begin{array}{l}\text { Element } \\
\text { determined }\end{array}$ & Method & $\begin{array}{l}\text { Det. Iimit } \\
\text { (ppm) }\end{array}$ & Reference \\
\hline $\begin{array}{l}\text { Gold (Au)----- } \\
\text { Mercury }(\mathrm{Hg})=-\end{array}$ & $\stackrel{A A}{A A C V}$ & $\begin{array}{l}0.05 \\
0.02\end{array}$ & $\begin{array}{l}\text { Thompson and others (1968). } \\
\text { Crock and others }(1987) \text {. }\end{array}$ \\
\hline $\begin{array}{l}\text { Arsentc (As)--- } \\
\text { Antimony (Sb)-- } \\
\text { Bismuth (Bi)--- } \\
\text { Cadmium (Cd)-- } \\
\text { zinc (2n)-- }\end{array}$ & $\begin{array}{l}\text { ICP } \\
\text { ICP } \\
\text { ICP } \\
\text { ICP } \\
\text { ICP }\end{array}$ & $\begin{array}{l}5 \\
2 \\
2 \\
0.1 \\
2\end{array}$ & $\begin{array}{l}\text { Crock and others }(1987) \text {. } \\
\text { Crock and others }(1987) . \\
\text { Crock and others }(1987) \text {. } \\
\text { Crock and others }(1987) \text {. } \\
\text { Crock and others }(1987) .\end{array}$ \\
\hline Fluorine $(F)$ & ISE & 0.01 & Hopkins (1977). \\
\hline
\end{tabular}

(highest values not considered anomalous) were determined by inspection of frequency-distribution histograms for each element.

In addition to the spectrographic analyses, all the rock and stream-sediment samples were analyzed for gold, arsenic, antimony, bismuth, cadmium, and zinc. Rock samples collected in 1988 were analyzed for mercury and fluorine by other analytical methods summarized in table 2 . Gold was analyzed by an atomic absorption spectroscopy method described by Thompson and others (1968). Arsenic, antimony, bismuth, cadmium, and zinc were analyzed by an inductively coupled plasma-atomic emission spectrometric method described by Crock and others (1987). Mercury was analyzed by a modification of the atomic absorption method described by Crock and others (1987), and fluorine was analyzed by an ion-selective electrode method described by Hopkins (1977).

\section{Results}

Minimum element values considered anomalous (above threshold values) for elements determined to be useful in this study are listed in table 3. These values were determined by visual inspection of frequency histograms of the elements and by comparing threshold values with element values that represent typical geochemical background levels (for example, O'Leary and Meier, 1986).

Stream-sediment samples had anomalous gold values, but otherwise did not reveal anomalous concentrations of other metals (table 3 ). Twelve samples contained $0.05 \mathrm{ppm}$ or more gold, including six samples from drainages north of the Ibapah pluton, three samples from drainages originating within the pluton, and three samples from drainages south of the pluton (pl. 1). Five of these drainages have mines or prospects within their basins, and the gold anomalies are presumed to have originated from these areas. However, seven drainages have no evidence of mining activity in their basins, and these gold anomalies may imply the presence of altered or mineralized rock within or close to these basins.

Analysis of the nonmagnetic fraction of heavymineral concentrate samples was the most useful geochemical method for the reconnaissance evaluation of the study area. Thorium, tin, tungsten, and beryllium occur in anomalous amounts in $\mathbf{1 8}$ or more of the 68 drainages sampled for heavy-mineral concentrates. Gold, silver, lead, zinc, bismuth, barium, molybdenum, and antimony occur in anomalous amounts only locally. Anomalous values and their sample localities for concentrate samples and anomalous gold values in

Table 3. Minimum element values considered anomalous and number of samples that are at or above these values for stream drainage samples from the Deep Creek Mountains Wilderness Study Area

[Gold values from stream-sediment samples; all other values are from heavy-mineral concentrate samples. All values in parts per million (ppm)]

\begin{tabular}{|c|c|c|}
\hline Element & $\begin{array}{l}\text { Min. } \\
\text { value }\end{array}$ & $\begin{array}{l}\text { No. of } \\
\text { samples }\end{array}$ \\
\hline $\begin{array}{l}\text { Gold- } \\
\text { Silver- } \\
\text { Barlum- } \\
\text { Beryllium- } \\
\text { Bismuth-- } \\
\text { Molybdenum-- }\end{array}$ & $\begin{array}{c}0.05 \\
7 \\
>10,000 \\
10 \\
20 \\
10\end{array}$ & $\begin{array}{r}12 \\
7 \\
11 \\
14 \\
11 \\
5\end{array}$ \\
\hline $\begin{array}{l}\text { Lead-- } \\
\text { Antimony- } \\
\text { Tin- } \\
\text { Thorium- } \\
\text { Tungsten- } \\
\text { Zinc- }\end{array}$ & $\begin{array}{r}1,000 \\
500 \\
100 \\
2,000 \\
100 \\
500\end{array}$ & $\begin{array}{r}5 \\
1 \\
11 \\
10 \\
19 \\
2\end{array}$ \\
\hline
\end{tabular}


Table 4. Minimum element values considered anomalous for rock samples, Deep Creek Mountains Wilderness Study Area

[All values in parts per million (ppm)]

\begin{tabular}{|c|c|}
\hline Element & $\begin{array}{l}\text { Minimum value } \\
\text { considered } \\
\text { anomalous }\end{array}$ \\
\hline $\begin{array}{l}\text { Gold- } \\
\text { Silver- } \\
\text { Copper- } \\
\text { Lead- } \\
\text { Zinc- } \\
\text { Molybdenum-- }\end{array}$ & $\begin{array}{c}0.05 \\
10 \\
500 \\
1,000 \\
1,000 \\
20\end{array}$ \\
\hline $\begin{array}{l}\text { Arsenic- } \\
\text { Antimony-- } \\
\text { Beryli lum-- } \\
\text { Bismuth } \\
\text { Barium- }\end{array}$ & $\begin{array}{r}100 \\
100 \\
20 \\
100 \\
>5,000\end{array}$ \\
\hline $\begin{array}{l}\text { Cadmium----- } \\
\text { Mercury---- } \\
\text { Manganese--- } \\
\text { Fluorine--- } \\
\text { Tin--- } \\
\text { Tungsten---- }\end{array}$ & $\begin{array}{c}100 \\
0.20 \\
>5,000 \\
1,000 \\
10 \\
50\end{array}$ \\
\hline
\end{tabular}

stream-sediment samples are shown on plate 1. Geochemical anomalies occur throughout the study area and suggest the presence of altered or mineralized rock.

About 215 rock samples were collected from within or near the study area. Rocks are in places anomalous in the elements gold, silver, mercury, arsenic, antimony, copper, lead, zinc, beryllium, fluorine, tin, molybdenum, tungsten, bismuth, barium, cadmium, and manganese (table 4). Anomalies from selected mines and prospect areas are summarized in table 5, and these areas are shown on plate 1 .

\section{Geophysics}

\section{Gravity}

The Deep Creek Range contrasts with nearby ranges (Lindsey, Zimbelman, Campbell, Bisdorf, and others, 1989; Lindsey, Zimbelman, Campbell, Duval, and others, 1989; Cox and others, 1989; Stoeser and others, 1990 ) in that it has no central gravity high. In general, gravity values decrease from east to west across the range (Bankey and Cook, 1989). This gradient represents the southwestern flank of a regional gravity high centered under the Great Salt Lake Desert (Stein and others, 1989) to the north and east of the study area. The

Table 5. Geochemical suites of anomalous elements in rock samples from in and near the Deep Creek Mountains Wilderness Study Area

\begin{tabular}{|c|c|}
\hline Area & Anomalous elements \\
\hline Goshute Canyon--_---- & $\begin{array}{l}\text { Gold, silver, copper, lead, zinc, } \\
\text { molybdenum, arsenic, antimony, mercury }\end{array}$ \\
\hline Willow springs--_--- & $\begin{array}{l}\text { Gold, silver, copper, lead, zinc, } \\
\text { cadmium, arsenic, antimony, manganese. }\end{array}$ \\
\hline Dewey mine--- & $\begin{array}{l}\text { Gold, silver, copper, lead, zinc, } \\
\text { cadmium, arsenic, antimony, mercury. }\end{array}$ \\
\hline Chokecherry Canyon--- & $\begin{array}{l}\text { Gold, silver, lead, arsenic, antimony, } \\
\text { mercury. }\end{array}$ \\
\hline Cougar Hill- & $\begin{array}{l}\text { Barium, mercury, lead, zinc, arsenic, } \\
\text { antimony, tungsten. }\end{array}$ \\
\hline $\begin{array}{l}\text { Ibapah pluton, } \\
\text { hematite-altered. }\end{array}$ & $\begin{array}{l}\text { Gold, silver, lead, molybdenum, tin, } \\
\text { tungsten, beryllium, bismuth. }\end{array}$ \\
\hline $\begin{array}{l}\text { Red Mountain-- } \\
\text { Queen of Sheba mine-- }\end{array}$ & $\begin{array}{l}\text { Silver, copper, zinc, molybdenum, tin. } \\
\text { Gold, silver, lead, arsenic. }\end{array}$ \\
\hline Gold Bond-_- & $\begin{array}{l}\text { Gold, copper, lead, zinc, bismuth, tin, } \\
\text { manganese. }\end{array}$ \\
\hline Trout Creek- & $\begin{array}{l}\text { Gold, silver, copper, lead, zinc, } \\
\text { cadmium, bismuth, molybdenum, tin } \\
\text { tungsten, fluorine, mercury, beryllium. }\end{array}$ \\
\hline
\end{tabular}




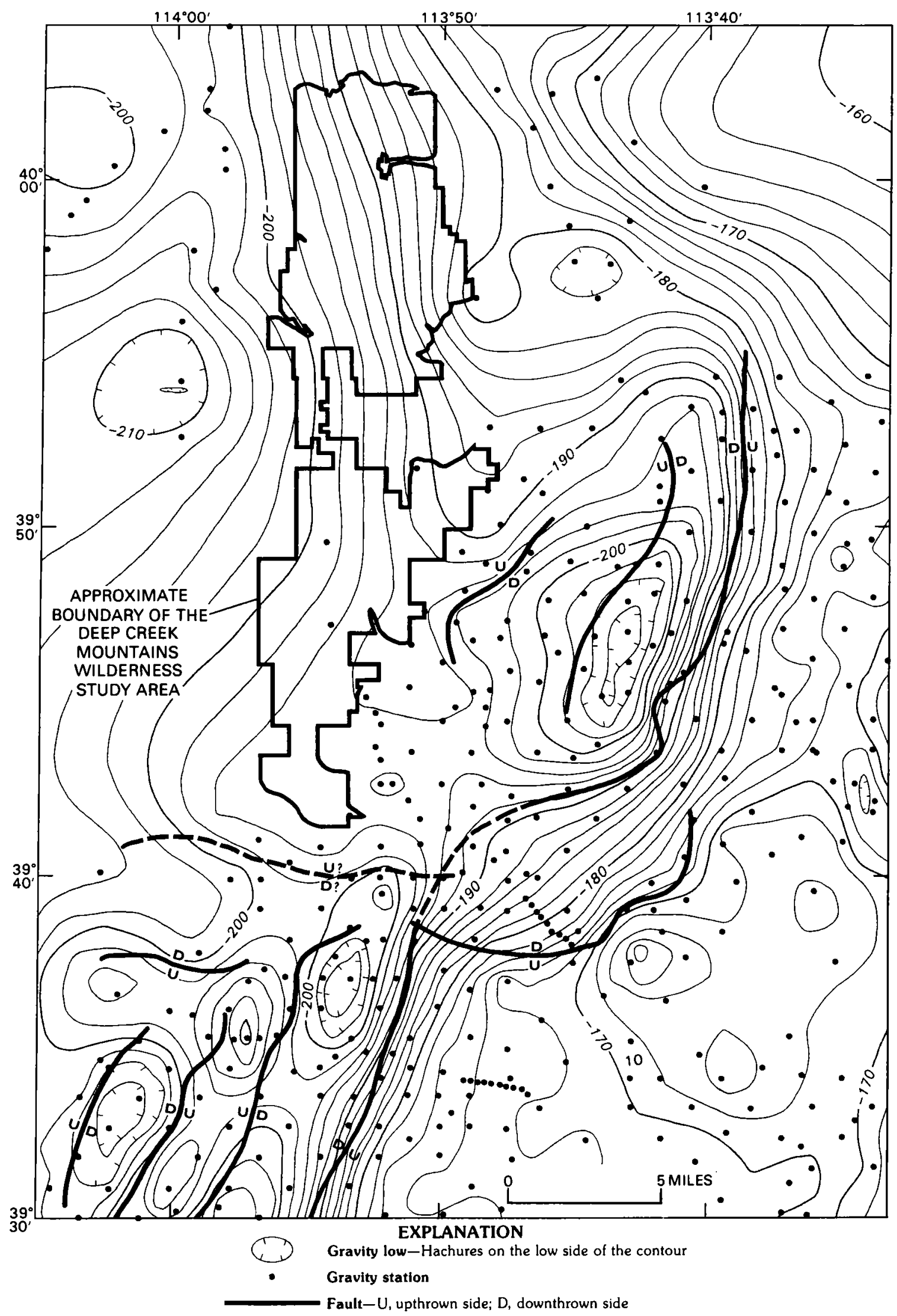

Figure 5. Locations of possible faults suggested by gravity gradients (Bankey and Cook, 1989). Only interpreted faults are shown where there are many gravity stations nearby to control their positions. Note that in many parts of this map gravity stations are sparse, so that faults cannot be inferred in those places. Contour interval, 2 milligals. 
southern part of the Deep Creek Range is bordered on the south and east by a line of lows that trends up the center of Snake Valley (Bankey and Cook, 1989). We interpret the line of lows as a graben buried under the sediments of Snake Valley (fig. 5). Such features relate to the regional setting of the Deep Creek Mountains Wilderness Study Area only. Gravity coverage of the study area itself is too sparse (only three or four gravity stations inside it) to reflect local geological details.

\section{Aeromagnetics}

Most of the aeromagnetic map of the study area (fig. 6) consists of a NURE (National Uranium Resource Evaluation) program survey (Texas Instruments, Inc., 1979) of the Delta $1^{\circ} \times 2^{\circ}$ topographic quadrangle, as processed and contoured by R.P. Kucks (USGS, unpub. data). The nominal line spacing for this survey was 1 and $2 \mathrm{mi}$ east-west and the nominal altitude was $400 \mathrm{ft}$ above ground level. Flight lines on figure 6 show that these specifications were not met very well over the rugged Deep Creek Range. In constructing figure 6, an additional 5-minute strip (Hildenbrand and others, 1983) was spliced along the north and west side of the Delta map. Original flight lines in this spliced-on area were spaced about $6 \mathrm{mi}$ apart and upward continued to a constant 12,000-ft elevation. A geophysical rule of thumb states that aeromagnetic surveys can detect anomalous bodies in a swath on the ground directly under the aircraft and about $45^{\circ}$ out from the vertical on each side. Under this rule, less than about 16 percent of possible magnetic sources on the ground surface would be detected by these surveys. Although the detection percentage increases for deeply buried bodies, small, shallow magnetic bodies between flight lines might remain undetected.

Magnetic features on figure 6 include an arcuate northeast-trending series of highs and lows (M, fig. 6 ) in the Snake Valley south and southeast of the study area, which reflect lavas on the surface or buried at shallow depths, and a rounded magnetic high $(\mathrm{H}$, fig. 6$)$ in the Great Salt Lake Desert just north of the village of Callao. Feature $\mathbf{H}$ reflects a body of magnetic intrusive rocks buried under the high. It is the westernmost of a series of three aeromagnetic highs that extend in a line to the east-southeast along the southern edge of the Great Salt Lake Desert. The easternmost of these highs lies over a stock found by drilling in the valley immediately west of the Fish Springs mining district, about $18 \mathrm{mi}$ to the east of the study area (Lindsey, Zimbelman, Campbell, Bisdorf, and others, 1989). Feature H, by analogy, may have been emplaced at the same time and may have caused the quartz veining and other indicators of mineralization seen along the northeastern parts of the Deep Creek Range.
The major magnetic feature inside the study area is a high-low polarity pair that reflects the Ibapah pluton (P, fig. 6). Lack of magnetic features elsewhere in the study area implies that other rocks there are nonmagnetic. At this magnetic latitude, the eastern and western edges of magnetic sources bodies lie under a contour on the magnetic anomaly map whose amplitude is roughly one-third of the maximum amplitude of anomaly due to the body. We infer, therefore, that the Ibapah pluton does not extend far beneath the Snake Valley to the east of the Deep Creek Range. We likewise infer that the Ibapah pluton extends for some distance west of the Deep Creek Range, although a shoulder on its magnetic anomaly (evident on the map of Hildenbrand and others, 1983) suggests that this western part of the pluton has been downfaulted. The north-extending lobe on the anomaly high is defined only along the tieline from $A$ to $A^{\prime}$; for some distance to the east of this lobe there are no data lines to define the anomaly shape, so the high might extend further to the north than the computer-generated contours show.

Magnetic data indicate that the Ibapah pluton may be rootless, either laccolithic or cut by a low-angle fault. This inference is supported by magnetic data. The critical piece of magnetic information is the polarity low north of the pluton. At this magnetic latitude, a thin plate-like body will have a sharp deep polarity low as part of its signature, whereas a deep-seated plug will have a wide but shallow polarity low. The Ibapah pluton has a deep but broad polarity low, arguing that it must be somewhat shallower than it is wide.

To model the pluton, we use data from $\mathbf{A}-\mathbf{A}^{\prime}$ on the north-south tieline. Because the tieline is not straight between $A$ and $A^{\prime}$, parts from the tieline were projected onto a profile line. This profile line passes over the Ibapah pluton, defining both its high and related polarity low, so is an ideal one for this purpose. The line crosses the pluton about $1.3 \mathrm{mi}$ east of its western magnetic shoulder and about $6.2 \mathrm{mi}$ west of its eastern edge. All shapes we used to model the pluton thereby were taken to extend $1.3 \mathrm{mi}$ to the west and $6.2 \mathrm{mi}$ to the east of the profile line.

Figure 7 is a histogram of the susceptibility values measured on outcrops of the Ibapah pluton. Assuming the values to be distributed log-normally, the sample median, $1,050 \times 10^{-5}$ S.I. (one S.I. unit $=1 / 4 \pi \mathrm{emu} / \mathrm{cm}^{3}$ ) is the best estimate to use for a representative susceptibility for the pluton. For modeling, this estimate represents a lower bound of "effective susceptibility" because aeromagnetic fields detect an additional remanent magnetization component that the susceptibility meter does not measure. For crystalline rocks like these, both 


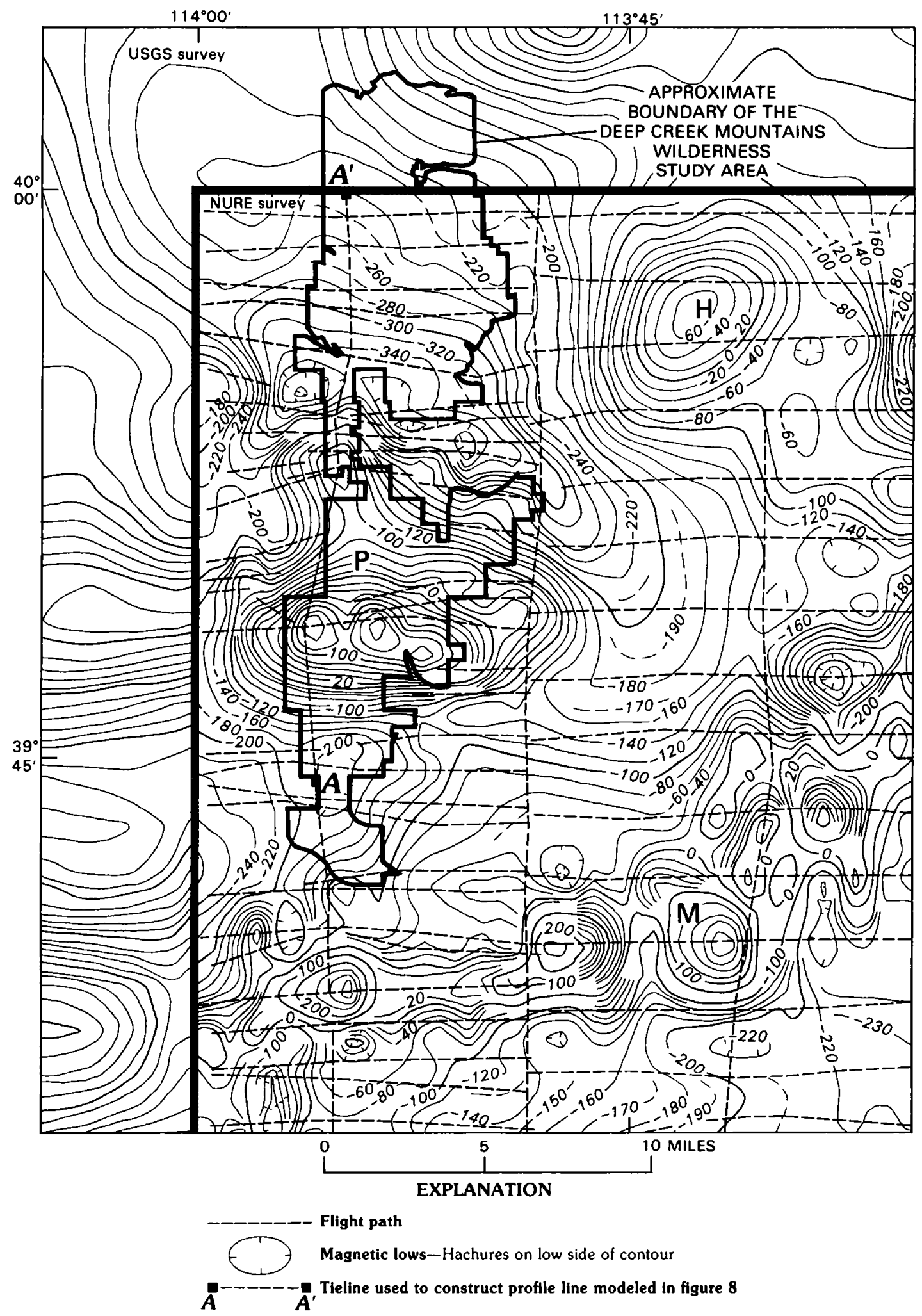

Figure 6. Aeromagnetic map of the Deep Creek Range Wilderness Study Area and vicinity, Juab and Tooele Counties, Utah. Contour interval: solid contours, 20 nanoteslas (nT); dashed contours, $10 \mathrm{nT}$. M, $\mathrm{H}, \mathrm{P}, \mathrm{H}=$ magnetic highs discussed in the text. Light stipple band separates U.S. Geological Survey (USGS) survey of Hildenbrand and others (1983) from the National Uranium Resource Evaluation (NURE) survey of Texas Instruments, Inc. (1979). 
components of magnetization usually align with the local magnetic field of the Earth (Grant, 1985, p. 308). Our model accordingly assumes a net vector magnetization in that direction.

Figure 8 shows models of two of the many possible shapes that we tried for the pluton. These models were made using a program by Campbell (1983). The survey aircraft is at the position shown by the dashes, representing the recorded distance it was above the ground at each sample point.

The shaded shape represents a pluton extending down to $6.2 \mathrm{mi}$ below sea level. Its susceptibility is $1,050 \times 10^{-5}$ S.I., the figure 7 median value. This model fails to produce the observed polarity low. It does, however, indicate two things. First, the effective susceptibility of the Ibapah pluton must be greater than $1,050 \times 10^{-5}$ S.I. so as to match the observed high at its south edge and the low to its north. This value implies that the rocks of the Ibapah pluton must have a remanent magnetization component in addition to the induced magnetization component measured by the susceptibility meter. Second, magnetic rocks of the pluton cannot extend as deep as the $6.2 \mathrm{mi}$ assumed here. It they did, they would produce a magnetic field that is greater than observed for some distance south of the pluton's southern outcrop border.

The patterned shape, which suggests a laccolithic body that may be cut by a fault and downdropped to the north, is one of a family of shapes that give good matches with observed fields near and outside the Ibapah pluton's outcrop borders. We favor this interpretation, but recognize that the shape could also represent a pluton that has an altered core in which magnetic minerals have been destroyed. All shapes in this family are less than about $2.5 \mathrm{mi}$ thick at their thickest part, extend in the subsurface to the south of the pluton's southernmost outcrop, are convex to the north, and are quite deep along the pluton's northern edge. We cannot expect a close match of observed and calculated fields over the pluton proper because the survey aircraft was flying close

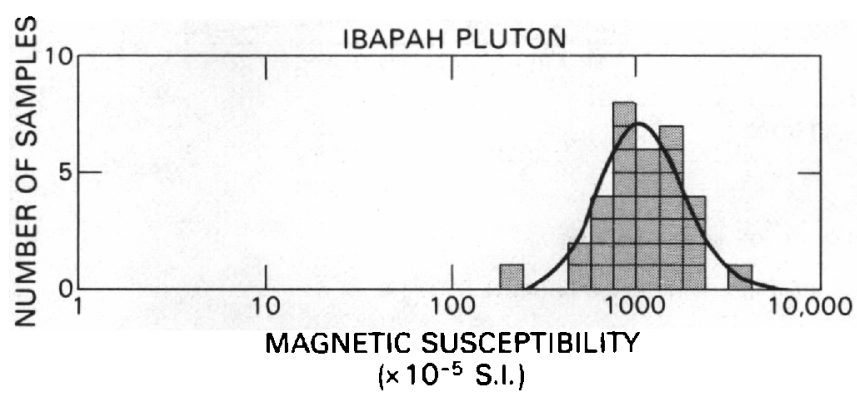

Figure 7. Histogram of measured magnetic susceptibilities of 33 rock samples from the lbapah pluton. A best-fit curve is drawn on the histogram that assumes the distribution is log normal. to rugged outcrops of magnetic rock there, and this complicated topography was not simulated in the calculation. The effective susceptibility of the body shown is $2,500 \times 10^{-5}$ S.I., and all bodies in the family have similarly large effective susceptibilities.

\section{Aeroradiometrics}

Aeroradiometric data were collected in 1977-79 along east-west and north-south trending lines crossing the study area (Texas Instruments, Inc., 1977, 1979). Aerial gamma-ray spectroscopy is a technique that provides estimates of the near-surface (0-20 in. deep) concentrations of percent potassium (K), parts per million equivalent uranium (eU), and parts per million equivalent thorium (eTh). Because the uranium and thorium measurements utilize radioactive daughter nuclei that are chemically distinct from the parent nuclei, the uranium and thorium data are described as equivalent concentrations. These data ( $K$, eU, eTh) provide us with a partial geochemical representation of the near-surface materials. For a typical aerial survey, each measurement represents average concentrations for a surface area on the order of 197,000 square feet to an average depth of about 12 in. Because the flightline spacings were about $3 \mathrm{mi}$, these data were only used to produce regional scale maps.

As part of a State mapping project, the data for Utah were compiled and processed to produce a series of 1:1,000,000 maps. These maps include contour and composite-color maps (the techniques for making the composite-color maps are described by Duval (1983)). The contour maps were examined to estimate the $\mathrm{K}$, eU, and $\mathrm{eTh}$ concentrations for each wilderness study area in Utah, and the occurrence or absence of anomalous radioelements concentrations on the composite-color maps were noted. The definition of an anomaly requires that the element concentration as well as its ratios to the other two elements all be high values in the context of the map.

The overall radioactivity of the Deep Creek Mountains Wilderness Study Area is moderate to high with potassium concentrations of $0.6-2.0$ percent, uranium concentrations of $1.5-4.5 \mathrm{ppm}$ eU, and thorium concentrations of 4-20 ppm eTh. Most of the higher thorium concentrations occur within the southern part of the study area, but these values are not seen as anomalous on the thorium composite-color map. Thorium anomalies are indicated on the east lobe of the southern part and west of the northern part. Thorium anomalies along the eastern edge of the Deep Creek Range appear to correlate with known deposits of thorite, monazite, zircon, and other radioactive minerals. 

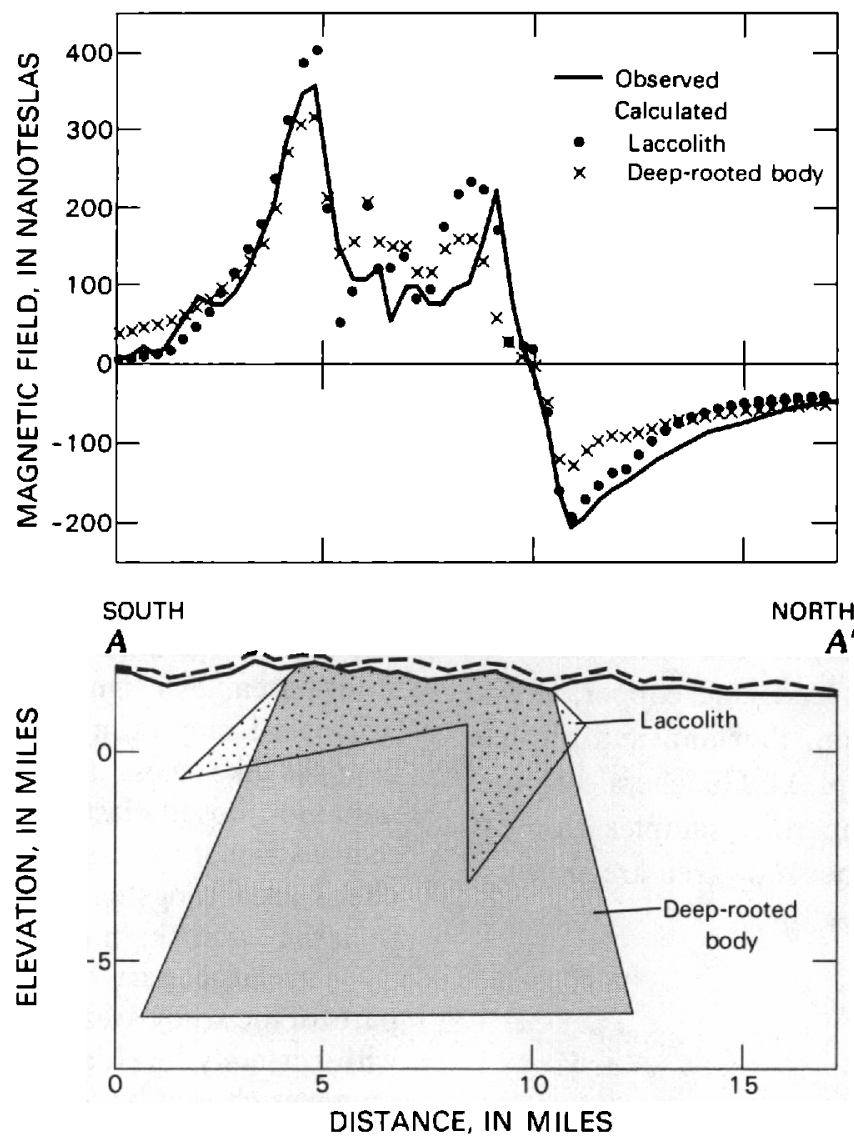

Figure 8. Models showing degree of fit with observed aeromagnetic field for different assumed shapes of the Ibapah pluton. Profile line shown on figure 6. Dashed line above profile shows recorded position of the survey aircraft. We conclude that the lbapah pluton is not a deep-rooted body such as the gray-shaded shape shown, but may be a laccolith like the patterned shape.

\section{Mineral and Energy Resource Potential}

The Deep Creek Mountains Wilderness Study Area is at the western margin of the Tintic-Deep Creek mineral belt of Hilpert and Roberts (1964) and south of the Gold Hill, or Clifton, mining district. The TinticDeep Creek mineral belt coincides with a belt of EoceneOligocene and Miocene igneous rocks and associated ores. The Eocene and Oligocene were characterized by eruption of calc-alkaline volcanic rocks, collapse of calderas, and intrusion of related porphyries. Porphyryrelated base- and precious-metal vein and replacement mineralization was associated with the calc-alkaline magmatic activity. In contrast, Miocene volcanic activity included eruption of basalt flows and alkali rhyolite flows and domes. The alkali rhyolite was associated with anomalous concentrations of lithophile elements, including beryllium, uranium, and fluorine (Lindsey,
1982; Moore and McKee, 1983). The most important Miocene deposits in the mineral belt are the world-class Spor Mountain beryllium deposit and deposits of fluorspar and uranium in the Thomas Range. At this time, low-grade gold deposits and prospects in western Utah, such as those in the Drum Mountains (Nutt and others, in press) and Confusion Range (Zimbelman, 1989), are of unknown age and igneous affinity.

The Gold Hill mining district is 2-4 miles north of the study area and produced tungsten, silver, gold, copper, lead, and arsenic (Nolan, 1935). This mining district is distinct in the mineral belt in that some of the ore is demonstrably genetically related to a Jurassic pluton (Stacey and Zartman, 1978). Some deposits are metasomatic skarns that formed near and in the Jurassic pluton. Beryllium-bearing quartz-carbonate veins crop out in Gold Hill (Griffitts, 1965) and, like beryllium ore at Spor Mountain, are Miocene (Whelan, 1970). 
The part of the Deep Creek Range within the study area contains deposits and prospects that have complex geochemical signatures not easily classified as Mesozoic or one of the two Tertiary times of mineralization. For example, the beryllium anomalies can be interpreted to indicate that the area is underlain by beryllium-enriched crust or that Miocene mineralization, typically berylliumrich, occurred in the Deep Creek Range. Even though isotopic data to constrain the ages of mineralization is lacking, we recognize the possibility of multiple episodes of mineralization.

Based on known deposits, geochemical anomalies identified by USGS sampling, and aeromagnetic features, the USGS evaluated the Deep Creek Mountains Wilderness Study Area for the favorability of tungsten, mercury, gold, silver, lead, zinc, copper, molybdenum, tin, beryllium, uranium, thorium, and oil, gas, coal, and geothermal energy (pl. 1). Geochemical suites of anomalous elements in the rock samples from 10 mineralized areas in or near the study area are shown in table 5.

\section{Tungsten}

Tungsten deposits near the study area are restricted to the Trout Creek area, which is just outside the eastern boundary. At the Trout Creek and Apex mines, tungsten was recovered from quartz-muscovite \pm fluorite \pm beryl veins in schist and carbonate rock and from metasomatically replaced carbonate rock near the contact of the alaskite at Trout Creek (Thomson, 1973). These deposits are small, probably in part because the deposits are associated with sills that lacked the fluids or heat needed to form larger deposits. To the north at Gold Hill, tungsten was mined from pipe-shaped replacement bodies, the largest of which is the Reaper deposit (Nolan, 1935).

Models for tungsten mineralization that could be applied to the study area are veins or skarns related to igneous bodies. Tungsten vein deposits, as described by Cox and Bagby (1986), are mostly associated with monzogranite to granite stocks. Fractures in the granitic rocks and wallrocks contain ore, typically in quartz veins, some of which have secondary muscovite along boundaries. Metasomatically replaced carbonate rock is known as skarn and is worldwide the major source of tungsten. Tungsten skarns typically occur in carbonatebearing rocks near coarse-grained, fairly deep-seated, granodiorite to quartz monzonite stocks and batholiths (Einaudi and others, 1981). The host rock is metasomatically replaced by a calc-silicate mineral assemblage and ore minerals.

\section{Pesource Potential}

In the Deep Creek Mountains Wilderness Study Area, areas favorable for the presence of small tungsten deposits similar to those at the Trout Creek area are shown on figure 9 and on plate 1 . This assessment is based largely on the occurrence of tungsten deposits in the Trout Creek area and at Gold Hill, as well as by the presence of tungsten in samples of heavy-mineral concentrates.

An area of high resource potential for small tungsten deposits, with certainty $\mathrm{C}$, is near the alaskite at Trout Creek. Although no alaskite crops out in this area of high resource potential, a contact aureole and a dome in the metasedimentary rocks, both features caused by intrusion of the alaskite (Rodgers, 1987), extend into the study area. An igneous body from which the sills originated may occur at depth and be associated with deposits like those at the Trout Creek area. Because metamorphosed clastic rocks are much more abundant than carbonate rocks in the study area near the Trout Creek area, tungsten vein deposits would be more likely than the large skarn deposits.

A large part of the northwestern and southern parts of the study area has a moderate resource potential, with certainty level B, for small tungsten deposits. This area was chosen by outlining clusters of drainage basins from which anomalous tungsten values were obtained from heavy-mineral concentrate samples (pl. 1; D.R. Zimbelman, U.S. Geological Survey, unpub. data). Although no skarn crops out in these drainage basins, the most northern part of the area with moderate resource potential is underlain by carbonate rocks, a favorable host rock for skarn deposits. The part of the Ibapah pluton in the area of moderate resource potential appears to be little altered, but Cadigan and others (1979) reported anomalous tungsten in a rock sample from the Ibapah pluton and more mineralized rock may occur at depth. The rest of the area has a low resource potential for tungsten, with certainty level $\mathrm{B}$.

\section{Mercury}

Rock samples from mining areas in the eastern, northern, and western part of the Deep Creek Mountains Wilderness Study Area contain anomalous mercury (table 5). Mercury was recovered from the Cougar Hill mine, which is not included in the western part of the study area.

An epithermal model can be applied to mercury concentrations at and near the Cougar Hill mine. At other places, mercury is most likely present as a trace element associated with gold and silver. Epithermal deposits form at low to moderate temperatures and 


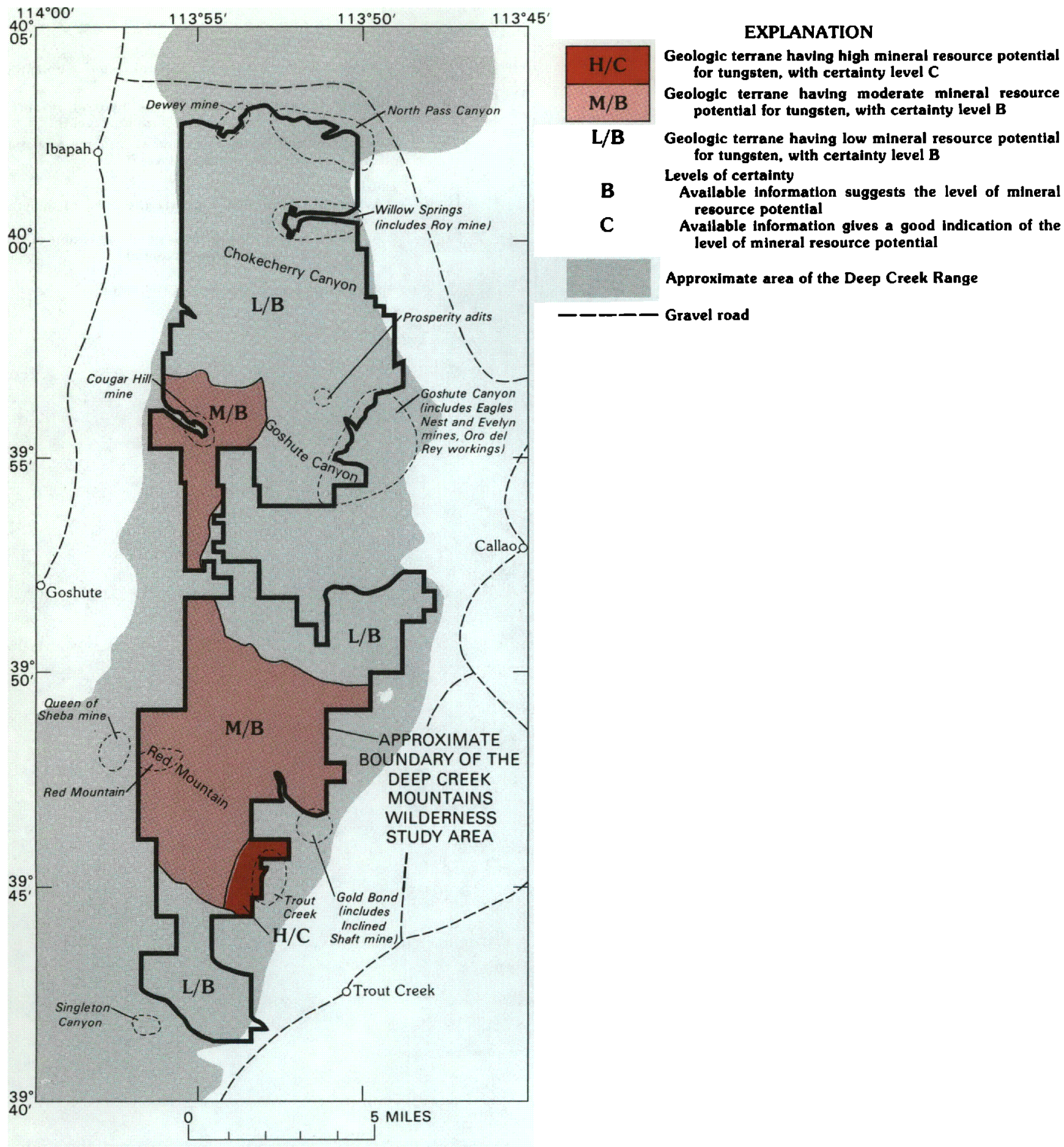

Figure 9. Mineral resource potential for tungsten in the Deep Creek Mountains Wilderness Study Area, Juab and Tooele Counties, Utah.

pressures in near-surface environments (Lindgren, 1933). In these systems, mercury tends to be concentrated in the upper or distal environments, where it is typically accompanied by such elements as antimony and arsenic (Rytuba, 1986).

\section{Resource Potentlal}

The northern part of the study area and the Trout Creek area are favorable areas for mercury deposits (fig. 10; plate 1). The resource potential for mercury is high, with certainty level $\mathrm{C}$, near the Cougar mine and all along 


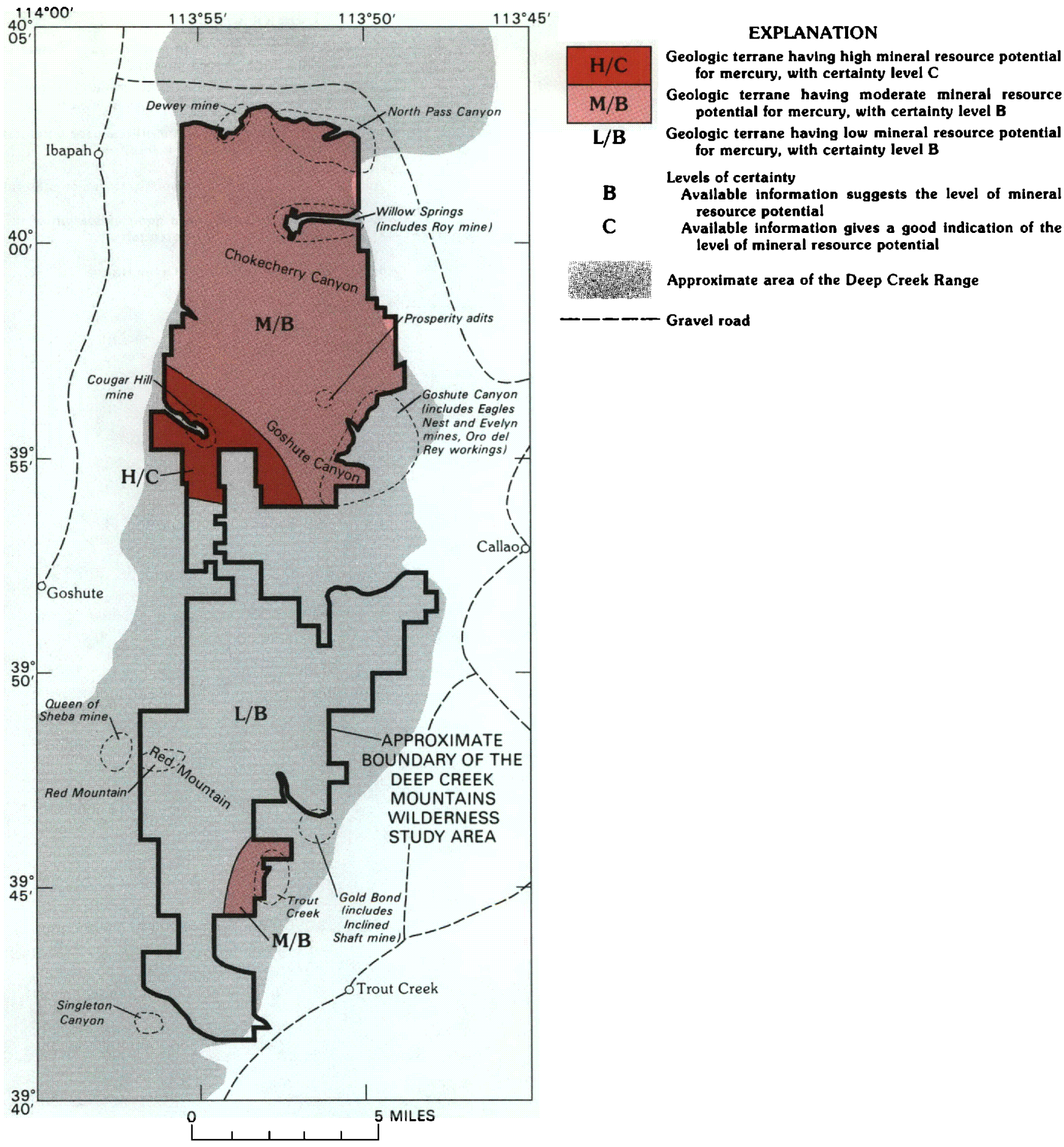

Figure 10. Mineral resource potential for mercury in the Deep Creek Mountains Wilderness Study Area, Juab and Tooele Counties, Utah.

the Rocky Springs thrust fault in the northwestern part of the study area. The fault juxtaposed quartzite and carbonate rock, both of which are fractured along and near the fault. Barium, mercury, lead, zinc, arsenic, antimony, and tungsten (table 5) are present in rocks at the mine, and mercury is anomalous in brecciated rocks along the trace of the Rocky Spring fault over a distance of about 3 miles. 
The resource potential for mercury deposits in the northern part of the study area outside the Rocky Springs thrust fault area is moderate, with certainty level B. This rating is based on the presence of anomalous mercury in rocks in the Goshute Canyon area, Chokecherry Canyon area, and Dewey mine (table 5). The Trout Creek area in the southern part of the study area contains rocks anomalous in mercury, and, therefore, has a moderate resource potential for mercury deposits, with certainty level $B$. The rest of the study area has a low resource potential for mercury deposits, with certainty level B.

\section{Gold and Silver}

In and near the Deep Creek Mountains Wilderness Study Area, gold and silver deposits and anomalies occur in a variety of settings. Known gold deposits (Goshute Canyon, Gold Bond, and Queen of Sheba) are near the eastern and western sides of the Deep Creek Range and are within $4 \mathrm{mi}$ of the Ibapah pluton. Silver was recovered from mines near the northeastern and northern boundaries of the study area (Willow Springs area, Dewey mine). Models considered appropriate for evaluation of gold and silver potential in the study area are vein and replacement, disseminated, and skarn deposits. In addition, deposits and prospects in the study area that do not obviously fit into any gold-silver model are classified as "other deposits."

Five parts of the study area have high to moderate resource potential for gold and silver (fig. 11, pl. 1). This evaluation is discussed in detail in the sections that follow. In summary, the favorable areas were delineated by (1) their proximity to known gold, silver, and mercury deposits; (2) gold- and (or) silver-bearing rock samples; (3) gold, silver, or the pathfinder elements mercury, arsenic, antimony, or barium in stream-sediment or heavy-mineral concentrate samples; (4) igneous rocks that are at least spatially associated with gold concentrations; and (5) geophysical evidence for buried igneous bodies. If stream-sediment and heavymineral concentrate samples contain gold, silver, or pathfinder elements, the drainage basin sampled has at least a moderate resource potential. In part because known gold and mercury deposits are localized near the Ibapah pluton in what could be a spatial but not genetic relationship, large areas on either side of the pluton are considered favorable for gold concentrations.

\section{Models and Mineral Resource Potential}

\section{VEIN AND REPLACEMENT}

The most productive known gold deposits near the Deep Creek Mountains Wilderness Study Area are goldbearing quartz veins cutting Late Proterozoic to Lower
Cambrian quartzite in the Goshute Canyon area east of the study area boundary. The veins are enriched in gold, silver, copper, lead, zinc, molybdenum, arsenic, antimony, and mercury (table 5). Gangue minerals in the veins consist almost entirely of quartz but include rare sericite, whereas sulfide minerals are pyrite, galena, and chalcopyrite. At the Devils Pit adits, Oro del Rey workings, and Eagles Nest mine, the veins are controlled by an approximately 8,000 -foot-long high-angle fracture system trending subparallel to the range front at about $10^{\circ}-15^{\circ}$ northeast and dipping steeply to the southeast (Thomson, 1973). At the Willow Springs area, Chokecherry Canyon, and Dewey mine, all of which are north of Goshute Canyon, small vein and replacement deposits are silver-rich and contain anomalous amounts of gold.

A model for mineralization in these vein deposits includes circulating fluids from which the quartz and gold were deposited; fractured host rock; and heating of fluids by deep circulation, proximity to an intrusive rock, or metamorphism. The Goshute Canyon area vein deposits are within $4 \mathrm{mi}$ of the Ibapah pluton, but die out as the pluton is approached, and, therefore, are probably not related to the exposed igneous body. More likely, mineralization was related to, or at least postdates, dikes of unknown age that are in the Goshute Canyon area. Where propylitically altered, these dikes are slightly enriched in gold. A high magnetic source northeast of Goshute Canyon is indicated by the aeromagnetic survey and may be due to buried intrusive rock. Gold and silver ore may be related to this or another buried igneous body.

\section{Resource Potential}

The resource potential for hydrothermal gold and (or) silver veins at depth in the eastern part of the study area near Goshute Canyon is high, with certainty level B. Although no major vein systems were noted in the study area, the proximity of the veins in Goshute Canyon and the presence of favorable host rocks at depth were criteria for the high rating. The presence of undiscovered ore is suggested by the gold in a stream-sediment sample north of the Goshute Canyon area. Anomalous lead was detected in heavy-mineral concentrate samples from above the Goshute Canyon deposits. The area near Goshute Canyon is underlain by the same Late Proterozoic to Lower Cambrian quartzites that host the Goshute Canyon deposits and by Paleozoic carbonate rocks. Both quartzites, which are extensively fractured in this area, and carbonate rocks, which are especially susceptible to replacement by silica, would be favorable hosts for gold-bearing quartz veins, and the carbonate rocks would be favorable hosts for disseminated deposits.

The northeastern part of the study area has an area of high resource potential, with certainty $B$, for gold and 


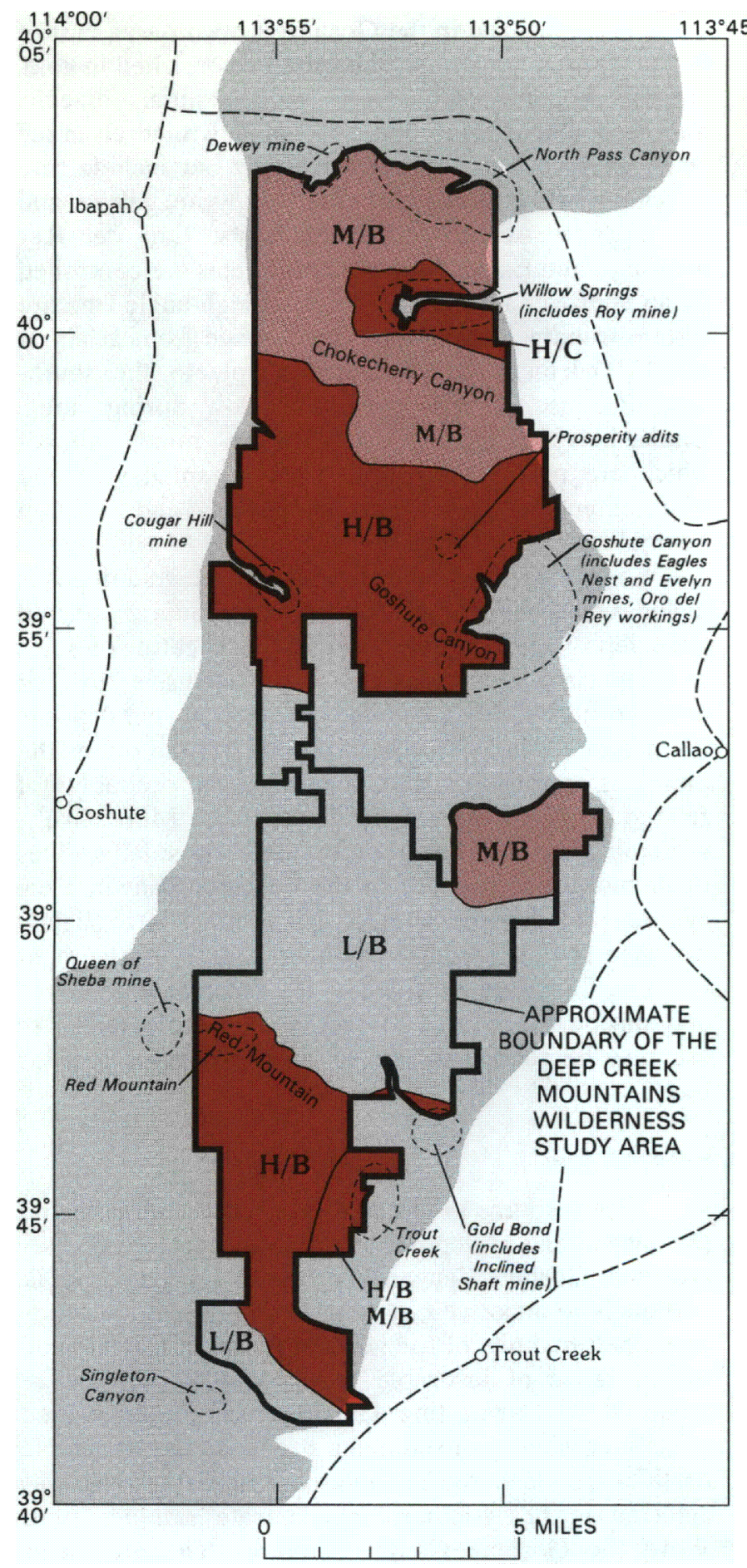

\section{EXPLANATION}

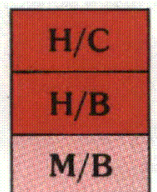

L/B Geologic terrane having low mineral resource potential for gold and silver, with certainty level $B$

B Levels of certainty

B Available information suggests the level of mineral resource potential

C Available information gives a good indication of the level of mineral resource potential

Approximate area of the Deep Creek Range

Figure 11. Mineral resource potential for gold and silver in the Deep Creek Mountains Wilderness Study Area, Juab and Tooele Counties, Utah.

silver. This area of high potential is in the vicinity of Willow Springs, where a subeconomic silver-rich vein and replacement deposit and rocks anomalous in gold occur. The quartzites and carbonate rocks in this area are favorable hosts for gold and (or) silver deposits in veins and as replacements of carbonate rocks. The area between the Willow Springs area and Goshute Canyon area, both of which have high resource potential, has moderate resource potential, with certainty B, for vein and replacement gold and (or) silver deposits. The rest of the study area has a low resource potential for gold vein and replacement deposits, with certainty level B. 


\section{DISSEMINATED}

Disseminated gold and silver deposits are not known in or near the Deep Creek Mountains Wilderness Study Area. In the Drum Mountains of west-central Utah, a small disseminated gold deposit in the lower part of the Paleozoic carbonate section was mined in the 1980's (Nutt and others, in press), and Paleozoic rocks throughout west-central Utah are currently being prospected for precious-metal deposits.

Disseminated sediment-hosted gold and silver deposits that formed at shallow (epithermal) to moderate (mesothermal) depths are major exploration targets in Nevada and Utah. These low-grade and high-tonnage deposits typically consist of fine-grained gold and (or) silver widely dispersed along many small fractures and faults in clay-, oxide- and (or) silica-replaced (jasperoid) rock. The classification as disseminated gold and (or) silver deposit is primarily descriptive because the genesis of these deposits is still unresolved (Bagby and Berger, 1985) and may include a variety of the Cox and Singer (1986) deposit types such as hot-spring, epithermal, carbonate-hosted, and gold-on-flat-faults, as well as the distal parts of porphyry copper-gold. Elements typically associated with gold and used as pathfinders are arsenic, antimony, mercury, thallium, and tungsten (Berger, 1986). Such minerals as pyrite, realgar, orpiment, arsenopyrite, cinnabar, fluorite, barite, and stibnite may accompany gold (Berger, 1986).

\section{Resource Potentlal}

The northwestern and north-central parts of the study area, near the Cougar Hill mercury mine and including the Rocky Spring thrust fault, have a high resource potential for disseminated gold and silver, with certainty level B. The presence of cinnabar and barite at the Cougar Hill mine and mercury anomalies in rocks cut by the Rocky Spring thrust fault over a distance of about $3 \mathrm{mi}$ suggest that an epithermal system may have mineralized the area. The fault juxtaposes carbonate rock and quartzite, both of which are fractured and are favorable host rocks. Heavy-mineral concentrate samples from the Cougar Hill drainage are anomalous in tungsten, and samples from streams to the north are anomalous in gold (pl. 1).

Some rocks in the northern part of the study area have a moderate resource potential for disseminated gold and silver, with certainty level $B$. This rating is based on the presence of geochemical anomalies and jasperoids in the North Pass Canyon area. An area of moderate resource potential is in the northern part of the Deep Creek Range where heavy-mineral concentrate samples are anomalous in barium and (or) the Middle Devonian Simonson Dolostone and the Upper and Middle Devonian Guilmette Formation crop out. In the Confusion
Range about $45 \mathrm{mi}$ to the south, anomalous barium in stream-sediment samples was the only indication of gold-barite-fluorite jasperoid prospects that are localized at and near the contact between the Simonson Dolostone and the Guilmette Formation (Zimbelman and others, 1989). Areas near Goshute Canyon and Willow Springs, which are rated as having high resource potential for gold and silver in vein and replacements, could also contain disseminated gold and (or) silver. The rest of the study area has a low resource potential for disseminated gold and silver deposits, with certainty level B.

SKARN

Gold skarns are not known in the study area, but were mined at such places as the Cane Spring and Midas mines in the Gold Hill mining district to the north (Nolan, 1935). The McCoy mining district in Nevada provides a model for gold-bearing skarn in which gold is in metasomatically replaced and (or) retrograde-altered chloritized limestone near an intrusive body (Kuyper, 1988).

\section{Resource Potential}

Skarn is exposed only near the alaskite at Trout Creek. Rock samples from the area are locally anomalous in gold, silver, and mercury as well as other elements (table 5). Gold, silver, and mercury mineralization most likely is related to retrograde alteration that followed primary formation of the skarn or to a later mineralization, which overprinted the skarn. Because of the presence of anomalous gold, silver, and mercury, unexposed gold and silver may be concentrated in the Trout Creek area. The study area near Trout Creek that may include unexposed skarn has moderate resource potential for gold and silver skarn, with certainty level B. The rest of the area has a low resource potential for gold and silver skarns, with certainty level B.

\section{Other Deposits, Not Classified as to Deposit Type}

\section{QUEEN OF SHEBA MINE}

About one mile west of the study area, gold was recovered from the Queen of Sheba mine where goldbearing quartz veins cut Late Proterozoic quartzite. These veins are not included with the veins at Goshute Canyon because of differences in geochemical signatures and because they are associated with igneous rock. Garnet-bearing alaskite and other intrusive rock, perhaps monzogranite of the Ibapah pluton, are reportedly exposed in underground workings (Thomson, 1973). Rock samples collected for the present study were anomalous in gold, silver, lead, and arsenic (table 5); unpublished data from Alan Fishler, the mine owner, 
describe greisen samples anomalous in gold, tin, and tungsten. Gold mineralization may have been related to the alaskite or may have overprinted earlier alaskiterelated alteration.

Resource Potentlal

The southern part of the Deep Creek Mountains Wilderness Study Area has a high resource potential for gold and silver veins similar to those at Queen of Sheba, with certainty B. Red Mountain, a nearby red-stained ridge, is underlain by schist and quartzite cut by dikes of garnet-bearing alaskite and porphyritic felsite. The source of some of the red coloring is weathered pyrrhotite in schist, but the USBM also reported pyrite-bearing quartzite. Rock samples from Red Mountain were anomalous in silver, copper, molybdenum, zinc, and tin. Anomalous gold and silver at the Trout Creek area is similar to gold anomalies at the Queen of Sheba mine in that they are near alaskite and associated tin anomalies. The favorable rating for the southern part of the study area was based on the rock anomalies that are similar to anomalies at the Queen of Sheba mine; the presence of alaskite; and the fact that parts of the area are underlain by quartzite, which hosts gold-bearing veins in both the Queen of Sheba mine and Goshute Canyon area.

\section{GOLD BOND}

The Gold Bond area, on the eastern side of the range and just outside the study area boundary, contains quartzites cut by fractures that were mined for gold. Rock samples are anomalous in gold, copper, lead, zinc, bismuth, tin, and manganese (table 5). Heavy-mineral concentrate samples that drain the area are anomalous in beryllium, tin, thorium, and molybdenum. The presence of beryllium and tin anomalies suggest that at least some mineralization may have been related to the alaskite at Trout Creek or the Ibapah pluton.

\section{Resource Polential}

The Deep Creek Wilderness Study Area to the west and south of Gold Bond has a high resource potential for gold and silver, with certainty level B. This rating is based on the occurrence of gold in the Gold Bond area and on the proximity of the Reilly Canyon fault and the Ibapah pluton.

\section{SOUTH OF TROUT CREEK AREA}

South of the Trout Creek area, two streamsediment samples from streams that drain the study area contained anomalous gold $(0.10 \mathrm{ppm})$. The source of the gold anomalies is unknown. No mining occurred in this area, but Cadigan and others (1979) reported anomalous amounts of the pathfinder elements thallium, antimony, and bismuth in rock samples. Because of these geochemical anomalies, this part of the study area south of the Trout Creek area has a high resource potential for gold, with certainty level $\mathrm{B}$.

IBAPAH PLUTON

Three stream-sediment samples from streams that drain the Ibapah pluton were anomalous in gold. The Ibapah pluton is cut only by small, discontinuous veins anomalous in silver, molybdenum, beryllium, tungsten, bismuth, copper, lead, and zinc (Cadigan and others, 1979), but contains a large zone of hematite altered and sheared rock locally anomalous in gold, silver, lead, molybdenum, tin, tungsten, beryllium, and (or) bismuth (table 5). Gold was anomalous in only one sample ( 0.05 ppm). In addition, Wallace (1986) noted chloritized and silicified monzogranite along the front of the Deep Creek Range near the Reilly Canyon fault and mostly outside the study area. The hematite-altered zone, as well as brecciated, chloritized, and silicified rock near the Reilly Canyon fault and outside the boundary, are likely hosts for the anomalous gold in the stream sediments. The resource potential for gold and silver in the altered and sheared parts of the Ibapah pluton is moderate, with certainty level B.

\section{Lead, Zinc, Copper, Molybdenum, and Tin}

The metals lead, zinc, copper, molybdenum, and (or) tin are found in anomalous concentrations in the northern and southern parts of the study area. Lead, zinc, and copper in and near the Deep Creek Mountains Wilderness Study Area, particularly the northern part, are concentrated in vein and replacement deposits that are probably related to buried intrusive rock. Lead, zinc, and copper concentrations are found at Willow Springs and Chokecherry Canyon, which are within the study area on the east side of the range, and at the Dewey mine, which is about $1 / 2 \mathrm{mi}$ north of the study area on the west side of the Deep Creek Range. The Willow Springs area contains rocks anomalous in gold, silver, copper, lead, zinc, cadmium, arsenic, antimony, and manganese (table 5 ) and contains a subeconomic deposit of silver, lead, zinc, and copper. This subeconomic deposit is not included in the study area.

Molybdenum and tin are anomalous in the southern part of the study area. These concentrations are near alaskite and most likely are related to magmatic and (or) hydrothermal fluids that circulated during intrusion of alaskite.

\section{Resource Potential}

Parts of the northern and southern study area are favorable for lead, zinc, and copper (fig. 12; pl. 1). 


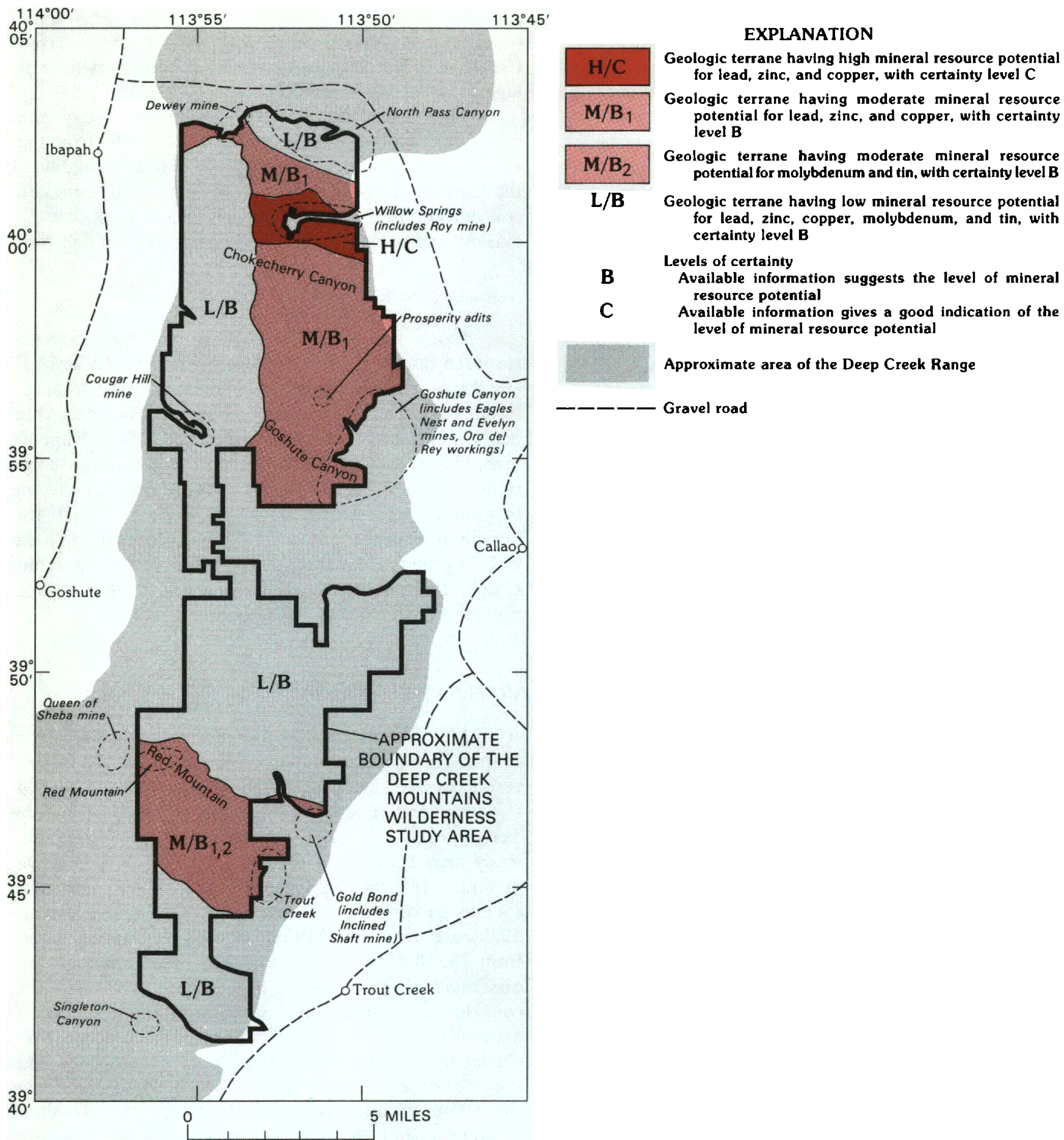

Figure 12. Mineral resource potential for lead, zinc, copper, molybdenum, and tin in the Deep Creek Mountains Wilderness Study Area, Juab and Tooele Counties, Utah.

Heavy-mineral concentrate samples collected from drainages in and near the Willow Springs area and Chokecherry Canyon were anomalous in silver, beryllium, bismuth, tungsten, and lead. Because of the presence of an exposed subeconomic deposit of silver, lead, zinc, and copper, and because the Paleozoic carbonate rocks that underlie the northern part of the area would be good hosts for veins and replacement deposits, the Willow Springs area has high resource potential for lead, zinc, and copper, with certainty level C. 
The area north of Willow Springs has moderate resource potential for lead, zinc, and copper, with certainty level B, because of its proximity to the Willow Springs mineralized area and because of the presence of anomalous copper, lead, and zinc at the Dewey mine just outside the northern boundary of the study area (table 5). The area south of the Willow Springs area has moderate resource potential for lead, zinc, and copper, with certainty level B, for the following reasons: (1) proximity to the Willow Springs mineralized area, (2) anomalous copper, lead, and (or) zinc in rocks from Chokecherry Canyon, Goshute Canyon (table 5), and from the Prosperity adits (Thomson, 1973), and (3) anomalous lead and zinc in some heavy-mineral concentrate samples from drainages. Veins of lead, zinc, and (or) copper could underlie the gold-rich veins at Goshute Canyon.

The southern part of the study area that includes the Queen of Sheba mine, Trout Creek area, and Gold Bond area has a moderate resource potential for lead, zinc, copper, molybdenum, and (or) tin, with certainty level B. Lead and zinc are anomalous in rock samples from the Queen of Sheba mine, Trout Creek area, and Gold Bond, and copper is anomalous in rock samples from Gold Bond (table 5). The area of moderate resource potential for molybdenum and tin was delineated primarily by anomalies in rocks and heavymineral concentrates and the proximity of alaskite. Both molybdenum and tin are anomalous in rocks and heavymineral concentrates from the Trout Creek area (table 5). In the Queen of Sheba mine area, tin is indicated by anomalous amounts in heavy-mineral concentrates (D.R. Zimbelman, U.S. Geological Survey, unpub. data) and by the report of tin greisen at the Queen of Sheba mine. Red Mountain, which is between the Trout Creek and Queen of Sheba mine area, is anomalous in both tin and molybdenum. The tin anomalies in heavy-mineral concentrates from drainages in the Ibapah pluton are probably from altered rock along the range front and outside the wilderness area or reflect pluton mineralogy, and these anomalies are not considered to indicate resource potential in the study area.

\section{Beryllium}

Beryllium is anomalous in heavy-mineral concentrate samples (pl. 1; D.R. Zimbelman, U.S. Geological Survey, unpub. data), but no known deposits exist. Ore-grade beryllium occurs north of the study area in quartz-carbonate veins in the Rhodenhouse Wash area of the Gold Hill mining district (Griffitts, 1965) and to the east at Spor Mountain. Within or near the study area, Thomson (1973) and A.R. Wallace (U.S. Geological Survey, oral commun., 1989) reported beryl in, respectively, pegmatites in the western part of the pluton and rare veins that cut the Ibapah pluton. Beryllium also occurs as beryl in muscovite-quartz-fluorite veins in the tungsten deposits associated with the alaskite at Trout Creek. In drill-hole samples, assays showed beryllium as high as 4.46 percent $\mathrm{BeO}$ (Thomson, 1973).

The most appropriate model for beryllium mineralization in the study area is a vein model from the Gold Hill mining district (Griffitts, 1965). In addition, the spatial association of beryllium and tungsten concentrations at the Trout Creek area suggest that the alaskite and nearby rocks could host beryllium deposits.

\section{Hesource Potentlal}

Large parts of the study area have moderate resource potential for beryllium, with certainty level $B$ (fig. 13; pl. 1). These areas are delineated by the drainage basins from which anomalous beryllium was detected in heavy-mineral concentrate samples (pl. 1; D.R. Zimbelman, U.S. Geological Survey, unpub. data). Because the tungsten deposits at the Trout Creek area are enriched in beryllium, an area of high resource potential for beryllium, with certainty level $\mathrm{C}$, coincides with the area of high potential for tungsten near the alaskite at Trout Creek. The rest of the study area has a low resource potential for beryllium, with certainty level $B$.

\section{Uranium and Thorium}

Much of the southern part of the study area and the Ibapah pluton were evaluated for uranium and thorium resources by the USGS at the request of the USBLM (Cadigan and others, 1979). They reported that only Tertiary and Quaternary placer deposits outside the study area contain anomalous amounts of radioactive minerals. Minerals in these placers include monazite, sphene, zircon, and allanite (U.S. Geological Survey, 1979) and probably thorite, all of which were derived from the Ibapah pluton. Because these minerals are disseminated throughout the stock, they are not considered anomalous concentrations. Thorium anomalies in heavy-mineral concentrate samples (pl. 1) cluster in drainages originating in the Ibapah stock and are due to the presence of accessory thorite derived from the monzogranite. Because there are no uranium anomalies, and thorium is present only in accessory thorite within the study area, the Deep Creek Mountains Wilderness Study Area has a low resource potential for uranium and thorium, with certainty level $\mathrm{C}$.

\section{Oil and Gas}

The Deep Creek Range has not been drilled for oil and gas. The resource potential for oil and gas in the Deep Creek Wilderness Study Area is low, with certainty 


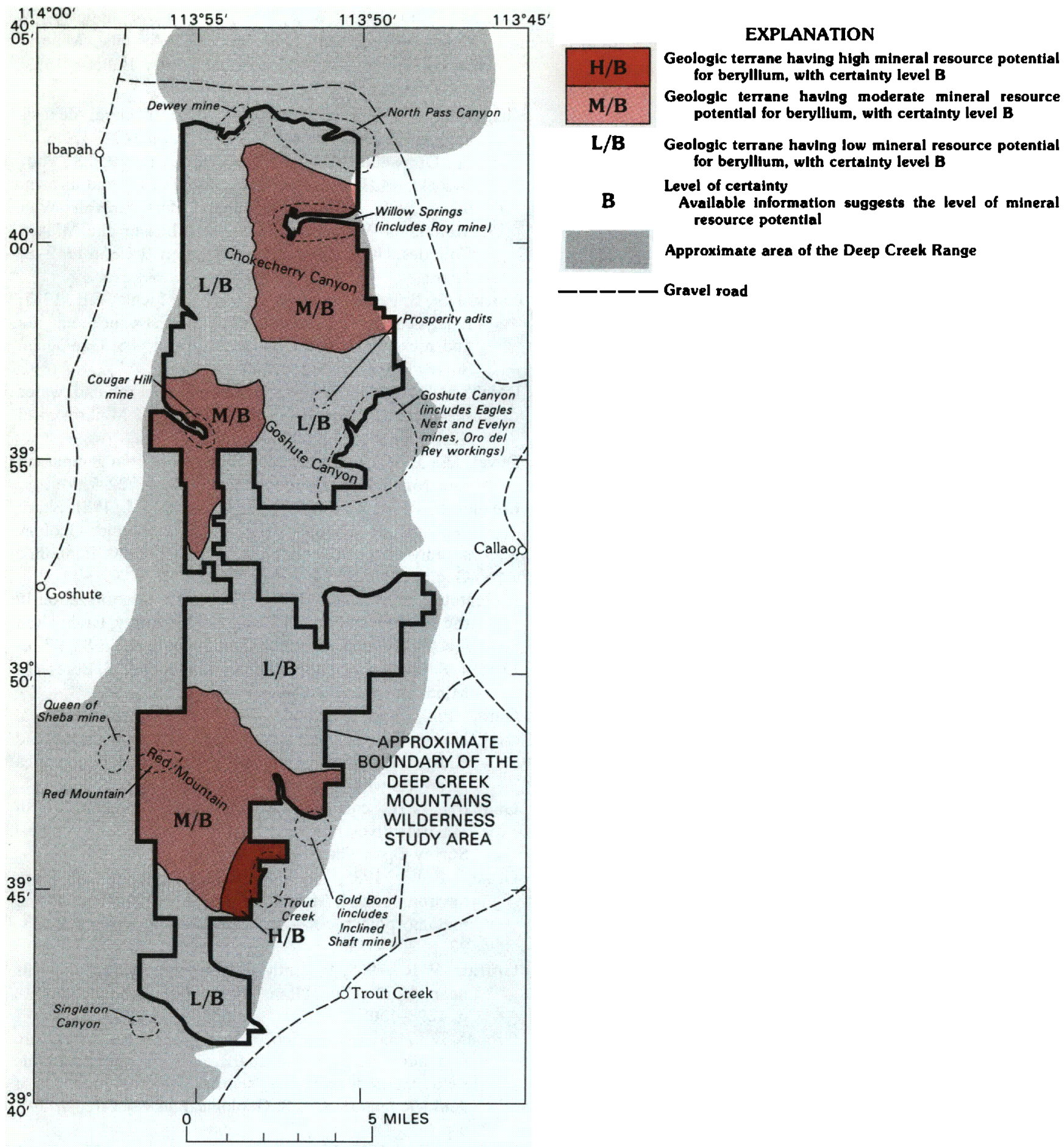

Figure 13. Mineral resource potential for beryllium in the Deep Creek Mountains Wilderness Study Area, Juab and Tooele Counties, Utah.

level $\mathrm{B}$, because the conodont $\mathrm{CAI}$ values in the vicinity indicate that hydrocarbons range from mature to overmature (Molenaar and Sandberg, 1983). Because the complex structure of the Great Basin obscures the geology at depth, the certainty level is not greater than B.

\section{Coal and Geothermal Energy}

The Late Proterozoic through Pennsylvanian rocks exposed in the Deep Creek Mountains Wilderness Study Area contain no coal, and coal is unlikely to occur in the 
subsurface. The resource potential for coal in the study area is low, with certainty level $D$. There are no hot springs or recent volcanic rocks in the study area. The resource potential for geothermal energy in the study area is low, with certainty level $\mathrm{D}$.

\section{Recommendations for Future Work}

The Deep Creek Mountains Wilderness Study Area is a large region that has seen only sporadic exploration activity for metals in the last few decades. Results from our study suggest that a number of ore minerals are present in the area, but a much more detailed geologic and geochemical study, including drilling, is necessary to confidently evaluate the study area.

\section{REFERENCES CITED}

Bagby, W.C., and Berger, B.R., 1985, Geologic characteristics of sediment-hosted, disseminated precious-metal deposits in the western United States, in Berger, B.R., and Bethke, P.M., eds., Geology and geochemistry of epithermal systems: Reviews in Economic Geology, v. 2, p. 169-202.

Bankey, Viki, and Cook K.L., 1989, Complete Bouguer gravity anomaly map and related geophysical maps of Delta $1^{\circ} \times 2^{\circ}$ quadrangle, Utah: U.S. Geological Survey Miscellaneous Field Studies Map MF-2081, scale $1: 250,000$ with auxiliary maps at $1: 500,000$ scale, 1 sheet.

Bates, R.L., 1969, Geology of the industrial rocks and minerals: New York, Dover Publications, 459 p.

Berger, B.R., 1986, Descriptive model of carbonate-hosted Au-Ag, in Cox, D.P., and Singer, D.A., eds., Mineral deposit models: U.S. Geological Survey Bulletin 1693, p. 175 .

Bick, K.F., 1966, Geology of the Deep Creek Mountains, Tooele and Juab Counties, Utah: Utah Geological and Mineralogical Survey Bulletin 77, 120 p.

Buie, B.F., and Robinson, G.C., 1958, Silica for glass manufacture in South Carolina: South Carolina State Development Board, Division of Geology, Bulletin 23, $41 \mathrm{p}$.

Butler, B.S., Loughlin, G.F., Heikes, V.C., and others, 1920, The ore deposits of Utah: U.S. Geological Survey Professional Paper 111, 672 p.

Cadigan, R.A., Nash, J.T., Zech, R.S., Wallace, A.R., Hills, F.A., and Robinson, Keith, 1979, Evaluation of the potential for uranium and other mineral resources in the Deep Creek Mountains withdrawal area: U.S. Geological Survey Open-File Report 79-1304, 74 p.

Campbell, D.L., 1983, BASIC programs to calculate gravity and magnetic anomalies for 21/2-dimensional prismatic bodies: U.S. Geological Survey Open-File Report 83-154, 31 p.
Cox, D.P., and Bagby, W.C., 1986, Descriptive model of W veins, in Cox, D.P., and Singer, D.A., eds., Mineral deposit models: U.S. Geological Survey Bulletin 1693, p. 64-66.

Cox, D.P., and Singer, D.A., eds., 1986, Mineral deposit models: U.S. Geological Survey Bulletin 1693, 379 p.

Cox, L.J., Duttweiler, K.A., Campbell, D.L., Duval, J.S., Podwysocki, M.H., Bankey, Viki, Cook, K.L., and Brown, S.D., 1989, Mineral resources of the Wah Wah Mountains Wilderness Study Area, Beaver and Millard Counties, Utah: U.S. Geological Survey Bulletin 1749-B, $21 \mathrm{p}$.

Crock, J.G., Briggs, P.H., Jackson, L.L., and Lichte, F.E., 1987, Analytical methods for the analysis of stream sediments and rocks from wilderness study areas: U.S. Geological Survey Open-File Report 87-84, 35 p.

Dasch, M.D., 1964, Gem materials, in Mineral and water resources of Utah: Utah Geological and Mineralogical Survey Bulletin 73, p. 169-170.

Duval, J.S., 1983, Composite color images of aerial gamma-ray spectrometric data: Geophysics, v. 48, p. 722-735.

Einaudi, M.T., Meinert, L.D., and Newberry, R.J., 1981, Skarn deposits, in Skinner, B.J., ed., Economic Geology seventy-fifth anniversary volume, 1905-1980: Economic Geology Publishing Co., p. 317-391.

El-Shatoury, H.M., and Whelan, J.A., 1970, Mineralization in the Gold Hill mining district, Tooele County, Utah: Utah Geological and Mineralogical Survey Bulletin 83, 37 p.

Everett, F. D., 1961, Tungsten deposits in Utah: U.S. Bureau of Mines Information Circular 8014, 44 p.

Gans, Phil, and Mahood, Gail, 1984, Syn-extensional intermediate to silicic volcanism in the eastern Basin and Range Province: Geological Society of America Abstracts with Programs, v. 16, p. 515.

Goudarzi, G.H., compiler, 1984, Guide to preparation of mineral survey reports on public lands: U.S. Geological Survey Open-File Report 84-787, 42 p.

Grant, F.W., 1985, Aeromagnetics, geology, and ore environments; I. Magnetite in igneous, sedimentary and metamorphic rocks-An overview: Geoexploration, v. 23, p. 303-333.

Griffitts, W.R., 1965, Recently discovered beryllium deposits near Gold Hill, Utah: Economic Geology, v. 60, p. 1298-1305.

Grimes, D.J., and Marranzino, A.P., 1968, Direct-current arc and alternating-current spark emission spectrographic field methods for the semiquantitative analysis of geologic materials: U.S. Geological Survey Circular 591, 6 p.

Hannigan, B.J., 1990, Mineral resources of a part of the Deep Creek Mountains Study Area (UT-020-060/ UT-050-020): U.S. Bureau of Mines Open-File Report MLA 1-90, $186 \mathrm{p}$.

Hildenbrand, T.G., Kucks, R.P., and Sweeney, R.E., 1983, Digital colored magnetic-anomaly map of the Basin and Range Province: U.S. Geological Survey Open-File Report 83-189.

Hilpert, L.S., 1964, Mercury, in Mineral and water resources of Utah: Utah Geological and Mineralogical Survey Bulletin 73, p. 108-111. 
Hilpert, L.S., and Roberts, R.J., 1964, Economic geology, in Mineral and water resources of Utah: U.S. 88th Congress, 2nd session, Committee Print, p. 28-34.

Hintze, L.F., 1978, Sevier orogenic attenuation faulting in the Fish Springs and House Ranges, western Utah: Brigham Young University Geology Studies, v. 25, part 1, p. 11-24.

1988, Geologic history of Utah: Brigham Young University Geology Studies Special Publication 7, 202 p.

Hopkins, D.M., 1977, An improved ion-selective electrode method for the rapid determination of fluorine in rocks and soils: U.S. Geological Survey Journal of Research, v. 5, p. 589-593.

Kuyper, B.A., 1988, Geology of the McCoy gold deposit, Lander County, Nevada, in Schafer, R.W., Cooper, J.J., and Vikre, P.G., eds., Bulk minable precious metal deposits of the western United States, Symposium proceedings: Reno, Nevada, The Geological Society of Nevada, p. 173-185.

Lindgren, W., 1933, Mineral deposits (4th ed.): New York, McGraw Hill, 930 p.

Lindsey, D.A., 1982, Tertiary volcanic rocks and uranium in the Thomas Range and northern Drum Mountains, Juab County, Utah: U.S. Geological Survey Professional Paper $1221,71 \mathrm{p}$.

Lindsey, D.A., Zimbelman, D.R., Campbell, D.L., Bisdorf, R.J., Duval, J.S., Cook, K.L., Podwysocki, M.H., Brickey, D.W., Yambrick, R.A., and Korzeb, S.L., 1989, Mineral resources of the Fish Springs Range Wilderness Study Area, Juab County, Utah: U.S. Geological Survey Bulletin 1745-A, 18 p.

Lindsey, D.A., Zimbelman, D.R., Campbell, D.L., Duval, J.S., Cook, K.L., Podwysocki, M.H., Brickey, D.W., Yạmbrick, R.A., and Tuftin, S.E., 1989, Mineral resources of the Swasey Mountain and Howell Peak Wilderness Study Areas, Millard County, Utah: U.S. Geological Survey Bulletin 1749-A, 21 p.

McCollum, L.B., and McCollum, M.B., 1984, Comparison of a Cambrian medial shelf sequence with an outer shelf margin sequence, northern Great Basin, in Geology of northwest Utah, southern Idaho and northeast Nevada: Utah Geological Association Publication 13, p. 35-44.

McKelvey, V.E., Mineral resource estimates and public policy: American Scientist, v. 60, p. 32-40.

Miller, E.L., Gans, P.B., Wright, J.E., and Sutter, J.F., 1988, Metamorphic history of the east-central Basin and Range Province; Tectonic setting and relationship to magmatism, in Emst, W.G., ed., Metamorphism and crustal evolution of the western United States: Englewood Cliffs, N.J., Prentice-Hall, Inc., p. 649-682.

Misch, P., and Hazzard, J.C., 1962, Stratigraphy and metamorphism of late Precambrian rocks in central northeastern Nevada and adjacent Utah: American Association of Petroleum Geologists Bulletin, v. 46, p. 289-343.

Molenaar, C.M., and Sandberg, C.A., 1983, Petroleum potential of wildemess lands in Utah, in Miller, B.M., ed., Petroleum potential of wilderness lands in the western United States: U.S. Geological Survey Circular 902-K, $14 \mathrm{p}$.
Moore, W.J., and McKee, E.H., 1983, Phanerozoic magmatism and mineralization in the Tooele $1^{\circ} \times 2^{\circ}$ quadrangle, Utah: Geological Society of America Memoir 157, p. 183-190.

Nelson, R.B., 1966, Structural development of the northernmost Snake Range, Kern Mountains, and Deep Creek Range, Nevada and Utah: American Association of Petroleum Geologists Bulletin, v. 50, no. 5, p. 921-951.

Nolan, T.B., 1935, The Gold Hill mining district Utah: U.S. Geological Survey Professional Paper 177, $172 \mathrm{p}$.

Nutt, C.J., Thorman, C.H., Zimbelman, D.R., and Gloyn, R.W., in press, Geologic setting and reconnaissance traceelement geochemistry of the Detroit mining district and Drum gold mine, Drum Mountains, Utah, in Raines, G.L., Schafer, R.W., and Wilkinson, W.H., eds., Geology and ore deposits of the Great Basin Symposium, Sparks, Nevada, 1990, Proceedings: The Geological Society of Nevada.

O'Leary, R.M., and Meier, A.L., 1986, Analytical methods used in geochemical exploration, 1984: U.S. Geological Survey Circular 948, 48 p.

Perry, L.I., and McCarthy, B.M., 1976, Lead and zinc in Utah: Utah Geological and Mineralogical Survey Open-File Report 22, 525 p.

Rodgers, D.W., 1984, Stratigraphy, correlation, and depositional environments of upper Proterozoic and Lower Cambrian rocks of the southern Deep Creek Range, Utah, in Kerns, G., and Kerns, R.L., Jr., eds., Geology of northwestern Utah, southern Idaho, and northeastern Nevada: Utah Geological Association Publication 13, p. 79-92.

1987, Thermal and structural evolution of the southern Deep Creek Range, west central Utah and east central Nevada: Palo Alto, Calif., Stanford University, unpublished $\mathrm{Ph} . \mathrm{D}$. dissertation, $149 \mathrm{p}$.

1989, Geologic map of the Deep Creek Mountains Wilderness Study Areas, Tooele and Juab Counties, Utah: U.S. Geological Survey Miscellaneous Field Studies Map MF-2099, scale 1:50,000.

Rytuba, J.J., 1986, Descriptive model of hot-spring $\mathrm{Hg}$, in Cox, D.P., and Singer, D.A., eds., Mineral deposit models: U.S. Geological Survey Bulletin 1693, p. 178.

Scott, D.C., 1986, Gold, silver, and tungsten resources of the Courthouse vein system, Sangre de Cristo Wilderness Study Area, Alamosa and Huerfano Counties, Colorado: U.S. Bureau of Mines Open- File Report MLA 52-86, 28 p.

Stacey, J.S., and Zartman, R.E., 1978, A lead and strontium isotopic study of igneous rocks and ores from the Gold Hill mining district, Utah: Utah Geology, v. 5, no. 1, p. 1-15.

Stein, Holly, Bankey, Viki, Cunningham, C.G., Zimbelman, D.R., Brickey, D.W., Shubat, Michael, Campbell, D.L., and Podwysocki, M.H., 1989, Tooele $1^{\circ} \times 2^{\circ}$ quadrangle, northwest Utah-A CUSMAP preassessment study: U.S. Geological Survey Open-File Report 89-0467, 133 p. 
Stoeser, D.B., Campbell, D.L., Labson, Victor, Zimbelman, D.R., Podwysocki, M.H., Brickey, D.W., Duval, J.S., and Cook, K.L., 1990, Mineral resources of the Notch Peak Wilderness Study Area, Millard County, Utah: U.S. Geological Survey Bulletin 1749-C., 28 p.

Texas Instruments, Inc., 1977, Aerial gamma-ray and magnetic survey of the Delta area, Utah; final report: U.S. Department of Energy Report GJBX-18(77). Available from Books and Open-File Reports Section, U.S. Geological Survey, Federal Center, Box 25425, Denver, CO 80225.

1979, Aerial radiometric and magnetic reconnaissance survey of the Delta quadrangle, Utah: U.S. Department of Energy Report GJBX-24(79), 576 p., 28 fiche. Available from Books and Open-File Reports Section, U.S. Geological Survey, Federal Center, Box 25425, Denver, CO 80225.

Thompson, C.E., Nakagawa, H.M., and Van Sickle, G.H., 1968, Rapid analysis for gold in geologic materials, in Geological Survey research 1968: U.S. Geological Survey Professional Paper 600-B, p. B130-B132.

Thomson, K.C., 1973, Mineral deposits of the Deep Creek Mountains, Tooele and Juab Counties, Utah: Utah Geological and Mineralogical Survey Bulletin 99, 76 p.
U.S. Bureau of Mines and U.S. Geological Survey, 1980, Principles of a resource/reserve classification for minerals: U.S. Geological Survey Circular 831, 5 p.

U.S. Department of the Treasury, 1971, Annual report of the direction at the mint for the fiscal year ended June 30 , 1971: p. 93.

U.S. Geological Survey, 1979, Geological Survey research 1979: U.S. Geological Survey Professional Paper 1150, p. 43-44.

Wallace, A.R., 1986, Mid-Tertiary shearing in the two-mica Ibapah stock, western Utah: U.S. Geological Survey Open-File Report 86-0151, 12 p.

Whelan, J.A., 1970, Radioactive and isotopic age determinations of Utah rocks: Utah Geological and Mineralogical Survey Bulletin 81, 75 p.

Woodward, L.A., 1965, Late Precambrian stratigraphy of the northern Deep Creek Range, Utah: American Association of Petroleum Geologists Bulletin, v. 49, p. 310-316.

Zimbelman, D.R., Hill, R.H., Fey, D.L., Arbogast, B.F., and Bullock, J.H., Jr., 1989, Selected analytical results, sample locality map, and discussion of trace-element anomalies for rock samples from near Kings Canyon, Confusion Range, Millard County, west-central Utah: U.S. Geological Survey Open-File Report 89-456, 16 p. 
APPENDIX 


\title{
DEFINITION OF LEVELS OF MINERAL RESOURCE POTENTIAL AND CERTAINTY OF ASSESSMENT
}

\author{
LEVELS OF RESOURCE POTENTIAL
}

H HIGH mineral resource potential is assigned to areas where geologic, geochemical, and geophysical characteristics indicate a geologic environment favorable for resource occurrence, where interpretations of data indicate a high degree of likelihood for resource accumulation, where data support mineral-deposit models indicating presence of resources, and where evidence indicates that mineral concentration has taken place. Assignment of high resource polential to an area requires some positive knowledge that mineral-forming processes have been active in at least part of the area.

M MODERATE mineral resource potential is assigned to areas where geologic, geochemical, and geophysical characteristics indicate a geologic environment favorable for resource occurrence, where interpretations of data indicate reasonable likelihood for resource accumulation, and (or) where an application of mineral-deposit models indicates favorable ground for the specified type(s) of deposits.

L LOW mineral resource potential is assigned to areas where geologic, geochemical, and geophysical characteristics define a geologic environment in which the existence of resources is permissive. This broad category embraces areas with dispersed but insignificantly mineralized rock, as well as areas with little or no indication of having been mineralized.

N NO mineral resource potential is a category resenved for a specific type of resource in a well-defined area.

$U$ UNKNOWN mineral resource potential is assigned to areas where information is inadequate to assign a low, moderate, or high level of resource potential.

\section{LEVELS OF CERTAINTY}

A Available information is not adequate for determination of the level of mineral resource potential.

B Available information only suggests the level of mineral resource potential.

C Available information gives a good indication of the level of mineral resource potential.

D Available information clearly defines the level of mineral resource potential.

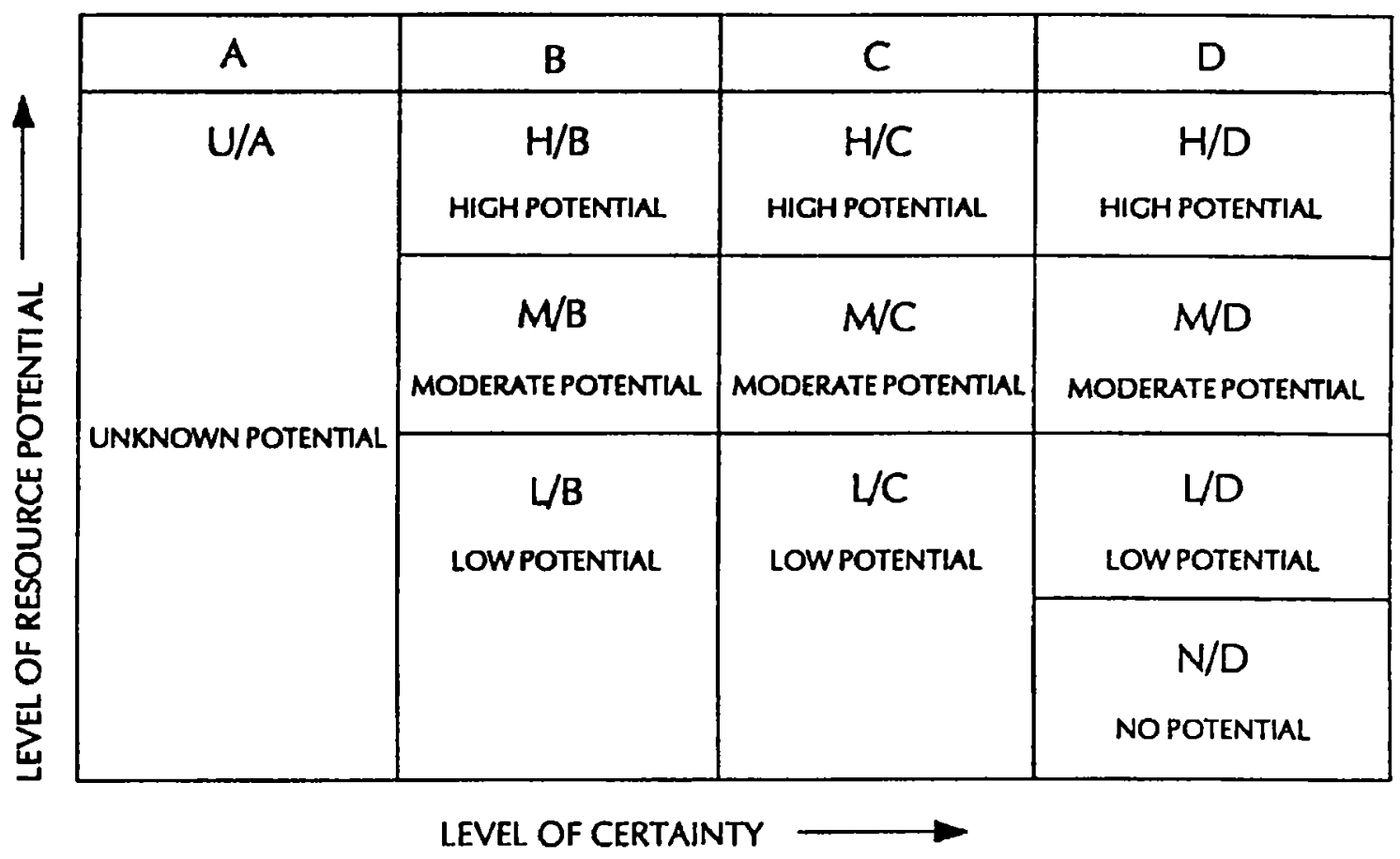

Abstracted with minor modificalions from:

Taylor, R.B., and Sleven, T.A., 1983, Definition of minesal resource potential: Economic Ceology, v. 78, no. 6, p. 1268-1270.

Taylor, R.B., Stoneman, R.J., and Marsh, S.P., 1984, An assessment of the mineral resource potential of the San tsabel National Forest, south-central Colorado: U.S. Geological Sumey Bulletin $1638, \mathrm{P}, 40-42$.

Coudarzl, G.H., compiler, 1984, Gulde to preparation of mineral survey reports on public lands: US. Ceological Survey Open-File Report 84-0787, p. 7, 8. 


\section{RESOURCE/RESERVE CLASSIFICATION}

\begin{tabular}{|c|c|c|c|c|c|}
\hline & \multicolumn{3}{|c|}{ IDENTIFIED RESOURCES } & \multicolumn{2}{|c|}{ UNDISCOVERED RESOURCES } \\
\hline & \multicolumn{2}{|c|}{ Demonstrated } & \multirow{2}{*}{ Inferred } & \multicolumn{2}{|c|}{ Probability Range } \\
\hline & Measured & Indicated & & Hypothetical & Speculative \\
\hline ECONOMIC & Res & & Inferred Reserves & & \\
\hline $\begin{array}{l}\text { MARGINALLY } \\
\text { ECONOMIC }\end{array}$ & Margin & leserves & $\begin{array}{c}\text { Inferred } \\
\text { Marginal Reserves }\end{array}$ & & \\
\hline $\begin{array}{c}\text { SUB- } \\
\text { ECONOMIC }\end{array}$ & $\begin{array}{r}\text { Demo } \\
\text { Subeconor }\end{array}$ & $\begin{array}{l}\text { rated } \\
\text { Resources }\end{array}$ & $\begin{array}{c}\text { Inferred } \\
\text { Subeconomic } \\
\text { Resources }\end{array}$ & & \\
\hline
\end{tabular}

Major elements of mineral resource classification, excluding reserve base and inferred reserve base. Modifled from McKelvey, 1972, Mineral resource estimates and public policy: American Scientiat, v.60, p.32-40, and U.S. Bureau of Mines and U.S. Geological Survey, 1980, Principles of a resource/reserve claselfication for minerale: U.S. Geological Survey Circular 831, p.5. 


\section{GEOLOGIC TIME CHART}

Terms and boundary ages used by the U.S. Geological Survey in this report

\begin{tabular}{|c|c|c|c|c|c|}
\hline EON & ERA & \multicolumn{2}{|c|}{ PERIOD } & EPOCH & $\begin{array}{c}\text { AGE ESTIMATES } \\
\text { OF BOUNDARIES } \\
\text { (Ma') }\end{array}$ \\
\hline \multirow{17}{*}{ Phanerozoic } & \multirow{7}{*}{ Cenozoic } & \multirow{2}{*}{\multicolumn{2}{|c|}{ Quaternary }} & Holocene & 10010 \\
\hline & & & & Pleistocene & \\
\hline & & \multirow{5}{*}{ Tertiary } & \multirow{2}{*}{$\begin{array}{l}\text { Neogene } \\
\text { Subperiod }\end{array}$} & Pliocene & {$\left[\begin{array}{l}1.5 \\
5\end{array}\right.$} \\
\hline & & & & Miocene & \\
\hline & & & \multirow{3}{*}{$\begin{array}{l}\text { Paleogene } \\
\text { Subperiod }\end{array}$} & Oligocene & \\
\hline & & & & Eocene & -50 \\
\hline & & & & Paleocene & -30 \\
\hline & \multirow{3}{*}{ Mesozoic } & \multicolumn{2}{|c|}{ Cretaceous } & $\begin{array}{l}\text { Late } \\
\text { Early }\end{array}$ & -96 \\
\hline & & \multicolumn{2}{|c|}{ Jurassic } & $\begin{array}{c}\text { Late } \\
\text { Middle } \\
\text { Early }\end{array}$ & -138 \\
\hline & & \multicolumn{2}{|c|}{ Triassic } & $\begin{array}{c}\text { Late } \\
\text { Middle } \\
\text { Early }\end{array}$ & 205 \\
\hline & \multirow{7}{*}{ Paleozoic } & \multicolumn{2}{|c|}{ Permian } & $\begin{array}{l}\text { Late } \\
\text { Early }\end{array}$ & {$[240$} \\
\hline & & \multirow{2}{*}{$\begin{array}{c}\text { Carbonilerous } \\
\text { Periods }\end{array}$} & Pennsylvanian & $\begin{array}{c}\text { Late } \\
\text { Middle } \\
\text { Early }\end{array}$ & 290 \\
\hline & & & Mississippian & $\begin{array}{l}\text { Late } \\
\text { Early }\end{array}$ & 5300 \\
\hline & & \multicolumn{2}{|c|}{ Devonian } & $\begin{array}{l}\text { Late } \\
\text { Middle } \\
\text { Early }\end{array}$ & 300 \\
\hline & & \multicolumn{2}{|c|}{ Silurian } & $\begin{array}{l}\text { Late } \\
\text { Middle } \\
\text { Early }\end{array}$ & 410 \\
\hline & & \multicolumn{2}{|c|}{ Ordovician } & $\begin{array}{c}\text { Late } \\
\text { Middle } \\
\text { Early }\end{array}$ & 435 \\
\hline & & \multicolumn{2}{|c|}{ Cambrian } & $\begin{array}{l}\text { Late } \\
\text { Middle } \\
\text { Early }\end{array}$ & 500 \\
\hline \multirow{3}{*}{ Proterozoic } & Late Proterozoic & & & & \\
\hline & Middle Proterozoic & & & & \\
\hline & Early Proterozoic & & & & 1000 \\
\hline \multirow{3}{*}{ Archean } & Late Archean & & & & \multirow{3}{*}{$\begin{array}{r}-3000 \\
+3400\end{array}$} \\
\hline & Middle Archean & & & & \\
\hline & Early Archean & & & & \\
\hline
\end{tabular}

'Millions of years prior to A.D. 1950

${ }^{2}$ Rocks older than 570 m.y. also called Precambrian, a time term without specific rank.

Informal time term without specific rank. 


\section{Mineral Resources of Wilderness Study Areas- Northwestern Utah}

This volume was published as separate chapters $A-C$ 


\section{DEPARTMENT OF THE INTERIOR MANUEL LUJAN, JR., Secretary \\ U.S. GEOLOGICAL SURVEY \\ Dallas L. Peck, Director}

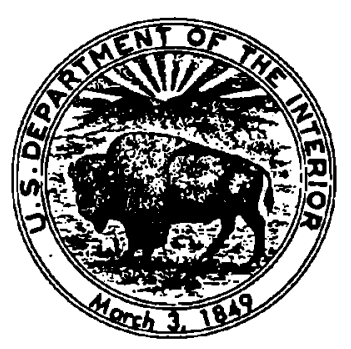




\section{CONTENTS}

[Letters designate the chapters]

A. Mineral resources of the Fish Springs Range Wilderness Study Area, Juab County, Utah, by David A. Lindsey, David R. Zimbelman, David L. Campbell, Robert J. Bisdorf, Joseph S. Duval, Kenneth L. Cook, Melvin H. Podwysocki, David W. Brickey, Robert A. Yambrick, and Stanley L. Korzeb

B. Mineral resources of the North Stansbury Mountains Wilderness Study Area, Tooele County, Utah, by Michael P. Foose, Karen A. Duttweiler, and Carl L. Almquist

C. Mineral Resources of the Deep Creek Mountains Wilderness Study Area, Juab and Tooele Counties, Utah by Constance J. Nutt, David R. Zimbelman, David L. Campbell, Joseph S. Duval, and Brian J. Hannigan 

